FINAL REPORT NO. 373

\title{
Precarious housing and wellbelng: a multi-dimensional investigation
}

Authored by

Rachel Ong ViforJ, Curtin University

Ranjodh Singh, Curtin University

Emma Baker, University of Adelaide

Rebecca Bentley, University of Melbourne

Jack Hewton, Curtin University 


\section{Title}

Precarious housing and wellbeing: a multi-dimensional investigation

\section{Authors}

Rachel Ong ViforJ, Curtin University

Ranjodh Singh, Curtin University

Emma Baker, University of Adelaide

Rebecca Bentley, University of Melbourne

Jack Hewton, Curtin University

\section{ISBN}

978-1-922498-40-3

\section{Key words}

Precarious housing, wellbeing, housing assistance.

\section{Series}

AHURI Final Report

\section{Number}

\section{ISSN}

1834-7223

\section{Publisher}

Australian Housing and Urban Research Institute Limited Melbourne, Australia

\section{DOI}

10.18408/ahuri8123801

\section{Format}

PDF, online only

URL

\section{https://www.ahuri.edu.au/research/final-reports/373}

\section{Recommended citation}

Ong ViforJ, R., Singh, R., Baker, E., Bentley, R. and Hewton, J. (2022) Precarious housing and wellbeing: a multidimensional investigation, AHURI Final Report No. 373, Australian Housing and Urban Research Institute Limited, Melbourne, https://www.ahuri.edu.au/research/finalreports/373, doi: 10.18408/ahuri8123801.

\section{AHURI}

AHURI is a national independent research network with an expert not-for-profit research management company, AHURI Limited, at its centre.

AHURI's mission is to deliver high quality research that influences policy development and practice change to improve the housing and urban environments of all Australians.

Using high quality, independent evidence and through active, managed engagement, AHURI works to inform the policies and practices of governments and the housing and urban development industries, and stimulate debate in the broader Australian community.

AHURI undertakes evidence-based policy development on a range of priority policy topics that are of interest to our audience groups, including housing and labour markets, urban growth and renewal, planning and infrastructure development, housing supply and affordability, homelessness, economic productivity and social cohesion and wellbeing.

\section{Acknowledgements}

This material was produced with funding from the Australian Government and state and territory governments. AHURI Limited gratefully acknowledges the financial and other support it has received from these governments, without which this work would not have been possible.

AHURI Limited also gratefully acknowledges the contributions, both financial and in-kind, of its university research partners who have helped make the completion of this material possible.

This report uses unit record data from the Household, Income and Labour Dynamics in Australia (HILDA) Survey. The HILDA Report was initiated and is funded by the Australian Government Department of Social Services (DSS) and is managed by the Melbourne Institute of Applied Economic and Social Research (Melbourne Institute). The findings and views reported in this paper, however, are those of the author and should not be attributed to either DSS or the Melbourne Institute. Rachel Ong ViforJ is the recipient of an Australian Research Council (ARC) Future Fellowship (project FT200100422) funded by the Australian Government.

\section{Disclaimer}

The opinions in this report reflect the views of the authors and do not necessarily reflect those of AHURI Limited, its Board, its funding organisations or Inquiry Panel members. No responsibility is accepted by AHURI Limited, its Board or funders for the accuracy or omission of any statement, opinion, advice or information in this publication.

\section{AHURI journal}

AHURI Final Report journal series is a refereed series presenting the results of original research to a diverse readership of policy-makers, researchers and practitioners.

\section{Peer review statement}

An objective assessment of reports published in the AHURI journal series by carefully selected experts in the field ensures that material published is of the highest quality. The AHURI journal series employs a double-blind peer review of the full report, where anonymity is strictly observed between authors and referees.

\section{Copyright}

(C) Australian Housing and Urban Research Institute Limited 2022

This work is licensed under a Creative Commons Attribution-NonCommercial 4.0 International License, see https://creativecommons.org/licenses/by-nc/4.0/.

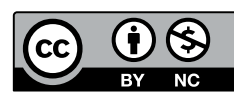




\section{Contents}

List of tables

List of figures $\quad$ iii

Acronyms and abbreviations used in this report

$\begin{array}{ll}\text { Executive summary } & 1\end{array}$

1. Introduction $\quad 7$

1.1 Why this research was conducted 8

\begin{tabular}{l}
1.2 Policy context \\
\hline
\end{tabular}

$\begin{array}{lr}1.3 \text { Existing research } & 11\end{array}$

1.4 Research methods $\quad 12$

1.4.1 The HILDA survey

1.4.2 Precarious housing dimensions 13

1.4.3 Wellbeing dimensions $\quad 14$

1.4.4 Precarious housing and wellbeing index construction $\quad 15$

1.4.5 Defining the 'precariously housed' 16

$\begin{array}{ll}\text { 1.4.6 Regressions } & 16\end{array}$

2. Precarious housing and wellbeing: dimensions, timing and housing assistance 17

$\begin{array}{lr}2.1 \text { Existing research } & 18\end{array}$

2.2 Precarious housing and wellbeing over time $\quad 19$

2.3 How does precarious housing affect wellbeing one year later? 23

2.4 How does wellbeing affect precarious housing one year later? $\quad 26$

2.5 How does housing assistance affect the wellbeing of precariously housed renters? 28

2.6 The timing of precarious housing experiences $\quad 30$

2.6.1 Precarious housing experiences across the life course

2.7 Some policy considerations $\quad 34$

3. Policy reflections $\quad 35$

3.1 Key findings for policy consideration

3.2 Policy options

$\begin{array}{ll}3.3 \text { Final remarks } & 38\end{array}$

References $\quad 39$

Appendix: Detailed regression tables $\quad 42$ 


\section{List of tables}

Table 1: Mean wellbeing score, by precarious housing dimension, 2002-2018

Table 2: Share with low wellbeing, precariously housed versus not precariously housed, by population subgroup, 2002-2018

Table 3: Effect of housing precariousness at t on wellbeing at $t+1$, fixed effects OLS models, 2002-2018

Table 4: Effect of wellbeing at $t$ on housing precariousness at $t+1$, fixed effects logit and OLS models, 2002-2018

Table 5: Effect of housing assistance at t on overall wellbeing at $t+1$ of renters in precarious housing, random effects OLS models, 2002-2018

Table A1: Regression control variables

Table A2: Effect of housing precariousness at $t$ on wellbeing at $t+1$, full regression results from fixed effects OLS models, 2002-2018

Table A3: Effect of wellbeing at $t$ on housing precariousness at $t+1$, full regression results from fixed effects logit and OLS models, 2002-2018

Table A4: Effect of housing precariousness and housing assistance at $t$ on overall wellbeing at $t+1$, random effects OLS models, 2002-2018

\section{List of figures}

Figure 1: Trends in mean precarious housing scores, 2002-2018

Figure 2: Trends in mean wellbeing scores, 2002-2018

Figure 3a: Change in wellbeing score at $t+1$ as a result of experiencing a precarious housing condition at $t$, expressed as a percentage of the mean wellbeing score at $t+1,2002-2018$

Figure $3 \mathrm{~b}$ : Change in wellbeing score at $t+1$ as a result of experiencing a precarious housing condition at $t$ expressed as a percentage of the mean wellbeing score at $t+1,2002-2018$

Figure 4: Movements in and out of a precariously housed status, by age band, 2002-2018

Figure 5: Share of those not precariously housed at $t$ who fall into precarious housing between $t$ and $t+1$, by major life event, 2002-2008

Figure 6: Share of the precariously housed at $t$ who remain in precarious housing between $t$ and $t+1$, by major life event, 2002-2008 


\title{
Acronyms and abbreviations used in this report
}

\author{
ABS Australian Bureau of Statistics \\ CNOS Canadian National Occupancy Standard \\ CRA Commonwealth Rent Assistance \\ EPRS European Parliamentary Research Service \\ GDP gross domestic product \\ OECD Organisation for Economic Cooperation and Development \\ OLS ordinary least squares \\ PCA principal component analysis \\ SEIFA Socio-Economic Indexes for Areas \\ SES Socio-economic status
}




\section{Executive summary}

\section{Key points}

- The wellbeing of singles, households with no children, low-income households, private renters and major city residents worsens when they are precariously housed.

- The gap in wellbeing between precariously housed and non-precariously housed people has widened over time.

- Forced moves and unaffordable housing have the most detrimental impact on wellbeing. The former results in a 1.6 per cent decline in the wellbeing index; the latter results in a 0.8 per cent decline in the wellbeing index. Forced moves and unaffordability also depress the mental health score by 1.7 per cent and 0.5 per cent respectively.

- Forced moves, unaffordability and neighbourhood hostility affect a greater range of wellbeing dimensions than other forms of housing precariousness.

- Satisfaction with finances is negatively impacted by forced moves $(3.4 \%$ decline) and unaffordable housing ( $2 \%$ decline).

- Satisfaction with the community is negatively impacted by neighbourhood hostility (with a $0.7 \%$ decline for each unit increase in the hostility score).

- The receipt of housing assistance does not have a statistically significant impact on the wellbeing of precariously housed renters. 
- Young people are more likely to fall into or remain in precarious housing than older people. Among the 25-34 years age band, 19 per cent fall into precarious housing and 24 per cent stay in precarious housing from year to year. On the other hand, only 4 per cent of the 65+ years age group fall into precarious housing and just 12 per cent stay in precarious housing from year to year.

- Physical violence precipitates entry into precarious housing, and lengthens time spent in it. Nearly one-quarter of those who suffer physical violence while not precariously housed fall into precarious housing in the following year. Three-quarters of those who suffer physical violence while precariously housed find themselves unable to escape into stable housing by the following year.

- Policy reform to increase tenure security in the private rental sector would increase the wellbeing of tenants.

- There remains significant scope for reforming existing housing-assistance programs to improving the wellbeing of the precariously housed through better targeting and integration of housing and non-housing measures.

\section{Key findings}

The relationship between housing precariousness and wellbeing across populations and over time

\footnotetext{
Over the period 2002-2018, the extent of precarious housing has fallen, with the mean precarious housing index declining from 1.14 to 1.05 points. This has been primarily due to a downward trend in neighbourhood crime. On the other hand, we find that the share of the population in unaffordable housing has risen over time, from 6 per cent in 2002, peaking at around 8 per cent in 2010 and stabilising at 7-8 per cent since. Despite a fall in mean precarious-housing index scores, the average wellbeing index has remained fairly constant. However, there are some distinct differences across wellbeing dimensions. For instance, average self-assessed mental health and physical health scores have declined slightly over time. Importantly, the gap in wellbeing between the precariously housed and non-precariously housed has widened over time.
}

\footnotetext{
Among the precariously housed, financial constraints and living in the rental sector predispose people to poorer wellbeing outcomes. People living alone, low-income households and public renters are most likely to report low wellbeing at any time point. When housing becomes precarious for a household, those most likely to suffer a drop in wellbeing are people who:

- have no children

- have low incomes

- $\quad$ are renting from a private landlord

- $\quad$ are residents of major cities.
} 
Clearly, there exists significant scope to better target housing policy measures towards the most vulnerable in the Australian population, and these groups (low income, private renters, people living alone, and people with wider financial constraints) should be prioritised.

\section{Dimensions of housing precariousness that affect wellbeing}

Forced moves and unaffordable housing stand out as being particularly strong drivers of a decline in wellbeing. Forced moves result in a decline of 1.6 per cent in the wellbeing index, while unaffordability depresses the wellbeing index by $0.8 \%$. Forced moves and unaffordability also depress the mental health score by 1.7 per cent and 0.5 per cent respectively. Satisfaction with finances is negatively impacted by forced moves ( $3.4 \%$ decline) and unaffordable housing ( $2 \%$ decline). However, neighbourhood conditions are not unimportant. For instance, satisfaction with one's community is negatively impacted by neighbourhood hostility, with a 0.7 per cent decline for each unit increase in the hostility score.

\section{Dimensions of wellbeing that affect housing precariousness}

Focussing on household conditions, we find financial satisfaction to be a key influencer of these outcomes. The odds of experiencing a forced move, unaffordable housing and overcrowding are all reduced when financial satisfaction grows. This is particularly evident regarding unaffordability. With each unit increase in the financial satisfaction score (which runs on a scale of 0 to 10), the odds of experiencing unaffordable housing declines by 6.8 percentage points. Satisfaction with one's community results in the greatest reduction in neighbourhood hostility, neighbourhood crime and Socio-Economic Indexes for Areas (SEIFA) score.

\section{Housing assistance and the wellbeing of precariously housed renters}

We find little evidence that housing assistance in its current form offers an effective means of improving the wellbeing of renters who are precariously housed. This finding is robust across alternative definitions of housing precariousness and is consistent across housing-assistance types. Therefore, there exists significant potential for housing assistance programs - both Commonwealth Rent Assistance (CRA) and public housing - to be reformed to increase their effectiveness in improving the wellbeing of precariously housed housing-assistance recipients.

\section{The timing of precarious housing experiences}

Average wellbeing decreases as individuals transition to higher levels of housing precariousness. The greatest decline in wellbeing occurs when non-precariously housed individuals first fall into precarious housing circumstances. Thus, it is important to understand how policy interventions can be timed to prevent people from falling into precarious housing in the first place, as well as how they can be timed to provide the greatest assistance to individuals in the midst of a transition into housing precariousness.

We find that young people are more vulnerable to falling into and remaining in housing precariousness than older age groups. Among the 25-34 years age band, 19 per cent fall into precarious housing and 24 per cent stay in precarious housing from year to year. On the other hand, only 4 per cent of the 65+years age group fall into precarious housing and just 12 per cent stay in precarious housing from year to year. Some major life events also precipitate transitions into precarious housing or prolonged spells in precarious housing. Twenty-two per cent of those who suffered physical violence while not precariously housed in the past year fall into precarious housing in the following year. Three-quarters of victims of physical violence who were in precarious housing in the past year find themselves unable to escape into stable housing by the following year. Furthermore, similar proportions of those who have been detained in jail in the past year also enter into or remain in precarious housing. 


\section{Policy development options}

The key findings in this report give rise to a series of important policy considerations and development options that broadly fall under the following policy domains:

- targeting

- regulation

- integration.

\section{Targeting of assistance towards the most vulnerable}

Financially constrained singles are most exposed to poor wellbeing outcomes when precariously housed. Young people are also more vulnerable to falling into and remaining in housing precariousness than older age groups. Clearly, there exists significant scope to better target housing policy measures towards the most vulnerable in the Australian population.

Various studies have suggested that households with children receive more generous welfare assistance than single households without children. Ong, Pawson et al. (2020) find that single private renters are most likely to be in housing stress but not receive CRA, while households with children are most likely to receive CRA while not being in housing stress. Similarly, Burke, Stone et al. (2011) find that single private renters face the greatest affordability problem, but the scale of the problem diminishes as the number of children increases. This suggests a need to consider both housing assistance and other forms of welfare, to ensure that they offer assistance in an equitable manner across different household types.

The current CRA structure is not an effective means of improving the wellbeing of precariously housed private renters. Various studies have suggested that the current CRA structure is ineffective in achieving a meaningful reduction in housing stress among low-income private renters (Henry, Harmer et al. 2010; Wood, Ong et al. 2011). The real value of CRA has fallen well behind rent inflation (Productivity Commission 2017) and there remains scope for improved targeting so that CRA entitlements more closely match the needs of different population cohorts (Henry, Harmer et al. 2010). Ong, Pawson et al. (2020) find that while over two-thirds of low-income private renters are assisted by CRA, one-third of low-income CRA recipients remain in moderate to very severe housing stress after CRA is deducted from their rents. They model various reforms to CRA and propose that changing CRA eligibility rules to better align with housing need would offer the greatest benefits by reducing the numbers of low-income rental tenants in housing stress by 44 per cent, while generating fiscal savings of $\$ 1.2$ billion per year.

\section{Regulation}

The findings from this report point to poor wellbeing scores among precariously housed public renters. They also suggest that when private renters fall into precarious housing, their wellbeing scores fall by a greater extent than other housing tenures. Related to this, forced moves are a key depressant of wellbeing. The scope for improving security of tenure in the rental sector is therefore significant. Lease terms and rent levels are currently lightly regulated in the private rental sector in Australia. A renter's security of tenure could be improved if they had the ability to exercise choice over tenancy length (Martin, Hulse et al. 2018). Tighter rent regulation or rent price control-as in countries such as Spain, Belgium and Germany — can also offer greater protection to tenants by preventing landlords from trying to 'price out' tenants in an attempt to end a tenancy (Iwata and Yamaga 2008; Minnery, Adkins et al. 2003). Abolishing 'without grounds' tenancy termination will also have the effect of improving security of tenure (Martin, Hulse et al. 2018). 


\section{Integration of housing and non-housing policy measures}

Vulnerability to precarious housing is greatest:

- in earlier stages of the life course

- when victim to physical violence

- when facing jail detention.

On their own, neither CRA nor public-housing assistance are effective in improving the wellbeing of the precariously housed. Therefore, there is a need for better integration of housing policy measures with non-housing measures, so as to offer an integrated approach to assisting those suffering from housing precariousness due to non-housingrelated factors. This may include whole-of-sector support for youths who are at risk of homelessness or facing prolonged unemployment, including assistance with job search and labour-market training, coupled with access to shelter.

Stronger protections against domestic violence that package both housing and non-housing support measures would also protect wellbeing. There is a need for better integration between domestic and family violence response and the wider housing system so those leaving violent relationships can access long-term, safe and appropriate housing (Flanagan, Blunden et al. 2019). Prisoners should be offered the assistance of trained case workers for housing, personal support and advocacy support both before and after their release from prison (Baldry, McDonnell et al. 2003).

\section{The study}

Wellbeing has become a critical and internationally recognised yardstick of societal progress and policy impact. Local, national and international policy makers have increasingly sought to measure whether citizens' quality of life is improving over time as a result of policy interventions - which is something that economic metrics fail to assess. Indeed, policy intervention in the area of housing has increasingly been viewed as a wellbeing issue, as well as an economic issue. Measuring the wellbeing impacts of policy rather than measuring economic growth puts individuals at the centre of evaluation.

Given the importance of housing for the wellbeing of the population, AHURI has in the past invested in research that has generated important and foundational findings on the empirical links between housing and wellbeing. With the passing of time and increasing sophistication of the conceptual understanding of wellbeing, this report represents a timely opportunity to further develop and expand our understanding of wellbeing in relation to Australian housing and our housing system.

This report will present comprehensive evidence that offers an up-to-date national picture on the links between precarious housing and wellbeing. Specifically, this report addresses four key research questions:

- How has the relationship between housing precariousness and wellbeing changed over time? Does the bi-directional relationship between housing precariousness and wellbeing vary by household type, income, housing tenure and/or geographical location?

- Which dimensions of housing precariousness affect wellbeing? Which dimensions of wellbeing affect housing precariousness?

- Does housing assistance mitigate the influence of housing precariousness on wellbeing?

- How can policy interventions be timed to effectively minimise any negative impacts of precarious housing on wellbeing? 
The report draws on the Household, Income and Labour Dynamics in Australia (HILDA) survey, a longitudinal survey that has been tracking a nationally representative sample of Australians annually since 2001. The HILDA survey is especially suitable for examining precarious housing and wellbeing, as it contains an extensive set of variables that enables population-wide conclusions to be drawn across a range of precarious housing and wellbeing dimensions. Therefore we are able to observe a rich array of household-based, precarious-housing dimensions_forced moves, unaffordable housing, overcrowding-as well as area-based precarious housing dimensions - neighbourhood hostility, neighbourhood crime, neighbourhood socio-economic status. In terms of wellbeing dimensions, we explore a myriad of variables related to satisfaction (with life, employment opportunities, finances, community) and self-assessed health (both mental and physical).

A dimensionality reduction technique called principal component analysis is applied to construct both a precarious housing index and a wellbeing index. The technique is widely used when there are a number of closely related variables and the researcher or analyst wants to allow the most significant influences from these variables to remain after the index is constructed. In the present context, it allows for separate factors to be combined into one measure, allowing for a holistic examination of precarity and wellbeing.

We employ panel data regression modelling to unpack the causal links between different dimensions of housing precariousness and wellbeing. Through regression modelling, we are able to isolate the independent effect that a precarious housing predictor might have on a wellbeing outcome, while controlling for other potentially confounding predictors.

There are at least two major advantages of panel data modelling compared to cross-sectional data modelling.

1. Panel data modelling has a greater capacity to detect causal effects than cross-sectional data modelling.

2. Panel data modelling has the ability to measure within-person differences over time-which is particularly important when analysing the subjective wellbeing responses of individuals. 


\section{Introduction}

- Policy intervention in the area of housing has increasingly been viewed through the lens of wellbeing. This wellbeing focus puts individuals at the centre of policy evaluation, rather than economic growth.

- This report generates a comprehensive evidence-base that offers an upto-date national picture on the links between precarious housing, housing assistance and wellbeing. It does this by:

- examining how the bi-directional relationship between housing precariousness and wellbeing varies across population subgroups and over time

- shedding light on the dimensions of housing precariousness that affect wellbeing, and vice versa

- investigating the role of housing assistance in mitigating the influence of housing precariousness on wellbeing

- offering a better understanding of how policy interventions should be timed to effectively minimise any negative impacts of precarious housing on wellbeing.

- The analysis draws on quantitative methods that include descriptive statistical analysis, panel data regression modelling and principal component analysis. 


\subsection{Why this research was conducted}

The ways in which we measure policy impact and societal progress are changing. Economic indicators such as gross domestic product (GDP) — the basis for the traditional evaluation of policy success - are no longer considered sufficient tools to measure the impact of non-economic policies, or the overall quality of life and general welfare of individuals (European Parliamentary Research Service [EPRS] 2014: 2). Wellbeing has become a critical and internationally recognised yardstick of societal progress and policy impact (EPRS 2014; Organisation for Economic Cooperation and Development [OECD] 2019).

Broadly defined, wellbeing refers to the ability of people to 'lead fulfilling lives with purpose, balance and meaning' -in other words, their quality of life (Treasury NZ 2019: 5). Wellbeing encompasses physical and mental health and safety; access to education, medical services and security; as well as environmental welfare and sustainability. Local, national and international policy makers have increasingly sought to measure whether citizens' quality of life is improving over time as a result of policy interventions-which is something economic metrics such as GDP fails to assess. As a result, governments and organisations have begun to focus more on ways to measure and track societal wellbeing, and to shape policies with these methods in mind.

Policy intervention in the area of housing has increasingly been viewed as a wellbeing issue - as well as an economic issue. A wellbeing focus to policy puts individuals at the centre of the evaluation of the success of housing policies, rather than economic growth. Given the importance of housing for population wellbeing, AHURI has invested in research that has generated important and foundational findings on the empirical links between housing and wellbeing (see for instance, Parkinson, Ong et al. 2014; Wood, Smith et al. 2013). With the passing of time and increasing sophistication of the conceptual understanding of wellbeing, this report represents a timely opportunity to further develop and expand the current evidence-base to improve our understanding of the important relationship between housing and wellbeing in Australia.

This report will present comprehensive evidence that offers an up-to-date national picture on the links between precarious housing and wellbeing. The report's contemporaneous findings are sensitive to current housing market contexts. Furthermore, the analysis accounts for the multi-dimensionality of both precarious housing and wellbeing concepts, to support the development of targeted and appropriately timed policy formulation. We will also investigate the case for housing-assistance reform by offering insights into the extent to which housing assistance might be effective in counteracting negative impacts of precarious housing on wellbeing.

Specifically, this report addresses four key research questions:

- How has the relationship between housing precariousness and wellbeing changed over time? Does the bi-directional relationship between housing precariousness and wellbeing vary by household type, income, housing tenure and/or geographical location?

- Which dimensions of housing precariousness affect wellbeing? Which dimensions of wellbeing affect housing precariousness?

- Does housing assistance mitigate the influence of housing precariousness on wellbeing?

- How can policy interventions be timed to effectively minimise any negative impacts of precarious housing on wellbeing?

The rest of Section 1 will further develop the policy context, review the background literature and set out the report's methodological approach. Section 2 will present key findings that address each key research question. Drawing on the key themes arising from Section 2, Section 3 will put forward a range of policy development options. 


\subsection{Policy context}

For over a decade, the measurement of wellbeing has been a key priority for the OECD, whose overarching mission was announced as 'Better Policies for Better Lives' during their 50th Anniversary celebrations in 2011 (OECD 2011: 5). The OECD Well-Being Framework comprises 11 dimensions, 'covering outcomes at the individual, household or community level' (OECD 2019: 2).

As measured by the OECD, the 11 dimensions of wellbeing are:

- income and wealth

- work and job quality

- housing

- health

- knowledge and skills

- environment quality

- subjective wellbeing

- safety

- work-life balance

- social connections

- civil engagement (OECD 2019: 2).

The OECD Better Life Index maps wellbeing in these 11 dimensions across countries, which enables global comparisons. Similarly, the European Parliament has introduced objective and subjective indicators to measure wellbeing in areas such as health, education, employment, living conditions and current life satisfaction (EPRS 2014: 4). Closer to home, the New Zealand government delivered a Wellbeing Budget in 2019 to track the nation's wellbeing, broadening the government's definition of policy success to prioritise its impact on people, communities and natural resources, as well as economic growth (Treasury NZ 2019: 2).

As evidenced by the OECD's Well-Being Framework, policy intervention in the area of housing has increasingly been viewed as a wellbeing issue - as well as an economic issue. Living in suitable and safe housing is one of the most important aspects of wellbeing. Housing access in relation to wellbeing encompasses:

- housing affordability, living conditions and overcrowding

- housing temperature and energy consumption

- public-housing access and support for those experiencing homelessness.

Recent research has highlighted the crucial relationships between housing and other aspects of wellbeing, including physical and mental health, environment quality and safety. Housing is also inherently tied to economic productivity, sustainability and growth. Thus, understanding the relationship between housing and other dimensions of wellbeing is essential to the development and evaluation of social and economic policy.

This increased interest in wellbeing in relation to housing and other areas has occurred alongside a period of rapid housing and urban transition and transformation across Australia. Housing prices have risen to a national average of over $\$ 700,000$ (Australian Bureau of Statistics [ABS] 2021), locking many out of home ownership (McKee 2012). These housing affordability pressures have contributed to a rise in long-term occupancy in housing tenures traditionally viewed as transitional, such as privately rented housing. The 2017-18 ABS Survey of Income and Housing estimated that 27 percent of Australian households lived in private rental houses, an increase from 20 percent in 1997-98 (Gurran, Hulse et al. 2021: 11). 
These changes have placed increased pressure on those groups most at risk of housing precariousness. Declining numbers of dwellings available to low-income households in recent years has been intensified by instances of moderate-income to higher-income households occupying low-rent dwellings (Gurran, Hulse et al. 2021: 11; Hulse and Yates 2017). The policy emphasis on increasing new rental housing supply has not improved the accessibility or availability of housing for lower-income renters (Buckle, Gurran et al. 2020: 7). Additionally, up to 1.1 million Australians live in very poor-quality or derelict homes, with many of these situated in the private rental sector or public-housing sector (Baker, Lester et al. 2016). There is increasing evidence-particularly within the rental sector-of tenure insecurity, limited tenant rights, unaffordability and poor dwelling conditions (Baker, Pham et al. 2021). Combined with other issues in the Australian housing sector-such as failure to meet demand for public housing and homelessness, as well as housing vulnerability to climate events such as bushfires and floods, thousands of Australians are currently living in precarious housing situations. While governments at state and federal levels have introduced schemes and policy initiatives to combat these housing issues, these policy suggestions cannot be fully effective or appropriate without up-to-date and cohesive research into housing, precariousness and wellbeing.

The existing challenges with Australia's housing stock — and in particular issues of precariousness and wellbeing - have been exacerbated over the past 18 months due to COVID-19. The economic, health and social impact of the pandemic has amplified existing inequalities within the housing sector-particularly between people who own their own home and those who rent, rely on public housing or are homeless. During the early stages of Australia's COVID-19 pandemic, many renters faced significant challenges, including tenure insecurity, housing unaffordability, and deteriorating housing conditions (Baker, Bentley et al. 2020: 3). Renters were also more likely to be impacted by the economic effects of COVID due to disproportionate employment in sectors most impacted by the economic shutdown, lower average wealth and slightly weaker attachment to the labour market (Baker, Bentley et al. 2020). Although state governments issued eviction moratoriums and other strategies to assist renters, the ongoing effects of COVID-19 have placed many renters into precarity. COVID-19 also influenced the re-evaluation of strategies surrounding the development and availability of public housing.

Temporary solutions were adopted at both a private and a governmental level throughout COVID-19 to respond to its impact on the housing sector. Individuals in many cases drew upon existing financial savings or superannuation to meet their living costs during the pandemic, and were often encouraged to do so by policy makers and organisations (Baker, Bentley et al. 2020).

Support payments for those unable to work due to economic shutdowns (JobKeeper) were introduced, along with increases in JobSeeker payments, in an attempt to mitigate the impacts of economic shutdowns, which in turn impacted the ability of households to continue to meet living costs. Similarly, rent deferments and eviction moratoriums - as well as deferments on mortgage payments-were similarly introduced to stem the impact of the pandemic on housing precariousness. Multiple state governments introduced a range of policy measures designed to provide temporary solutions for rough sleepers and homeless people, alongside housing security for those relying on public housing (Nygaard, Pinnegar et al. 2021: 9).

However, at the time of writing in October 2021, these temporary solutions have begun to taper, with many already having ended by the beginning of 2021. As a result, the full impact of COVID-19 on the Australian housing sector is yet to be fully realised, with the effect on housing precariousness and wellbeing likely to continue to emerge in coming months and years. 


\subsection{Existing research}

It is well established that precarious housing negatively affects mental health and wellbeing in Australia. The prevalence of precarious housing has been estimated nationally (see for example Beer, Bentley et al. 2016) and mapped as a geography (for example Baker, Lester et al. 2019). The relationship between precarious housing and health has been described in terms of its bi-directional nature (Baker, Mason et al. 2014), the interaction between precarious housing and precarious employment, known as 'double precarity' (Bentley, Pevalin et al., 2016), with shocks such as disability acquisition (Aitken, Baker et al. 2019), and the consequences for children's health of experiencing instability in their housing (Baker, Lester et al. 2019).

Across multiple studies, precarious housing has been classified and measured in different ways. Mallett, Bentley et al., (2011: 24), highlight that when considering housing, there is 'no consensus in the literature on the use of the term "precarious"'. In responding to this, their early analysis defined precarious housing as a combined phenomena that includes affordability, suitability and housing insecurity. Beer, Bentley et al. (2016) classify people as being precariously housed if they experience two or more of the following:

- unaffordable housing costs

- living in private rental

- experiencing a forced residential move in the preceding 12 months.

With a focus on home ownership, Wood, Smith et al. (2017) conceptualise precariousness as occurring on the 'edges', where people may be at risk of falling out of homeownership through unemployment, financial stress, health shocks or indebtedness. The earlier work of Hulse and Saugeres (2008) examining broader precariousness viewed housing insecurity largely through a lens of tenure. The recent work by Clair, Reeves et al. (2019) examines its prevalence across 31 European countries, and operationalises housing precariousness as a combination of housing affordability, security, accessibility and quality. Of course, all estimates of the prevalence of housing precarity are highly dependent on the definition and measure applied. For example, using 2010 data, the study by Beer, Bentley et al. (2016) estimates that just under 40 per cent of lone parents with young children were precariously housed, in comparison with just 3 per cent of couples with children who were estimated to be precariously housed.

Evidence suggests that there is a bi-directional relationship between precarious housing and poor health, with precarious housing clearly identified in the research literature as 'both a source and a symptom of disadvantage' (Baker, Lester et al. 2016). These relationships, running in different directions, are causal. There is strong evidence from analyses of longitudinal datasets that precarity - measured, in this case, using affordability as a proxyinfluences mental health outcomes (Bentley, Baker et al. 2011), and that poor health influences precarity outcomes (Mallet et al. 2011). These findings demonstrate the entwined and complex nature of the housing and health relationship that creates difficulties for people in less secure tenures such as private rentals (Stone, Rowley et al. 2020).

Qualitative evidence further supports this conceptualisation of the relationship between precarious housing and health as being both bi-directional and complex. Young single mothers interviewed in a Melbourne-based study focussed on documenting the effects of housing precarity (Mallett, Bentley et al. 2011), clearly identify a causal link between precarious housing and generalised stress, which they reported often resulted in heightened levels of anxiety and depression. This in turn affected their parenting capacity as well as their ability to participate in employment, education and training and the general community. The young women in this study also reported that lack of affordability, insecurity and unsuitability impacted, singly and in combination, on the health and wellbeing of their children.

Housing precarity also does not occur in isolation from other aspects of people's lives. It is often a change in people's employment circumstances, household composition or income that triggers housing precarity. In recent research Bentley, Pevalin et al. (2016) examine the 'double precarity' of employment and housing precariousness - as measured by relative affordability stress-using a nationally representative longitudinal cohort. People from insecurely employed households had five times greater odds of also experiencing housing 
precariousness (odds ratio (OR) 4.99, 95\% confidence interval (Cl) 4.21-5.90). The analysis highlighted key cohorts-such as single parents, people who live alone and people who were recently separated or divorcedas especially vulnerable to double precarity. Importantly, housing was estimated to account for 20 per cent of the total negative effect of precarious employment on mental health, suggesting that some of the psychosocial burden of precarious employment could be alleviated by providing housing security.

Research has also identified populations that are particularly disadvantaged in the housing system, resulting in a higher burden of housing precarity alongside other challenges ('multiple precarity'). Australian adults with disabilities experience more housing disadvantage than their non-disabled counterparts, including homelessness, poor-quality housing, and housing unaffordability. Aitken, Baker et al. (2019) analysed data from a nationally representative sample of 11,394 working-age Australians and find that people with disabilities experience disadvantage across multiple measures of precarity, including affordability, quality and security. Secure housing can buffer people from external shocks in their employment and health circumstances. For example, Kavanagh et al. (2016) found that deterioration in mental health following the 'shock' of acquiring a disability in adulthood was moderated by the security and affordability of their housing.

\subsection{Research methods}

\subsubsection{The HILDA survey}

The HILDA survey is a longitudinal survey that tracks a nationally representative sample of individuals and households over time. This survey has been collecting data annually since 2001 and the latest wave of data collection, at the time of this report's analysis, was 2018. While the HILDA survey is available from 2001, we draw on the waves from 2002 onwards as data on moves are not available for 2001. This data is important for observing experiences of forced moves, which are a key form of housing precariousness.

The HILDA survey is particularly suitable for examining precarious housing and wellbeing for several reasons. It contains a rich set of critical housing precariousness and wellbeing variables that enables population-wide conclusions to be drawn across a range of precarious housing and wellbeing dimensions. Information related to an individual's precarious housing circumstances such as tenure status, reasons for moving, income spent on housing costs, the number of people living in the same dwelling relative to the amount of bedrooms and neighbourhood characteristics are all important. Equally important are the wellbeing variables in the HILDA survey that span a myriad of domains, from satisfaction to SF-36 health measures covering both mental and physical functioning. (See Subsection 1.4.3 for more about SF-36.)

There are at least two major advantages of panel data compared to time series data and cross-sectional data. Panel data provides:

1. the ability to analyse dynamic relationships-for example, the HILDA survey allows us to observe when people fall into precarious housing across time, and when they escape precarious housing.

2. the ability to measure changes within the same individual over time-which is particularly important when analysing the subjective wellbeing responses of individuals.

We combine independent adult respondents aged 15 years or over in all waves into a person-period dataset, resulting in over 250,000 cases or person-periods. The dataset is unbalanced, with individuals able to be counted more than once in the dataset. Hence, if an individual is interviewed in all 17 waves from 2002 to 2018 , the individual contributes 17 person-periods to the dataset. If the individual is not interviewed in all waves, the individual will contribute less than 17 person-periods to the dataset. For instance, if an individual is interviewed in 2003-2007 and then again in 2016-2018, the individual will contribute eight person-periods to the dataset. 


\subsubsection{Precarious housing dimensions}

In this subsection, we describe the different precarious housing measures employed for this report. These can be broadly categorised as:

- household-based precarious housing conditions

- area-based precarious housing conditions.

Household-based dimensions

A person is classified as experiencing 'forced moves' if they reported a change in address since their last interview and also answered 'yes' to one of three questions in the HILDA survey that asked their main reason for moving. The questions relate to whether:

- they were evicted,

- they were in government housing and had no choice

- the property was no longer available.

Those who could not pay their mortgage or rent on time in the last year and had changed address since their last interview are also defined as having experienced a forced move. Forced moves are a form of tenure insecurity. While not all private renters are in precarious housing, we also analyse the impacts of private renting on wellbeing, as there is widespread evidence-based agreement that private renting is a more insecure form of tenure in Australia than either home ownership or public renting.

The 30/40 rule is applied to measure 'unaffordable housing'. A person is classified as being in unaffordable housing if their household spends more than 30 per cent of their gross income on housing costs and their equivalised' household disposable income is in the lowest 40 per cent of the income distribution (Rowley, Ong et al. 2015).

Individuals are classified as living in 'overcrowded housing' if the number of bedrooms in their dwelling is less than those specified in the Canadian National Occupancy Standard (CNOS) (ABS 2016a; Mallett, Bentley et al. 2011), which states that:

- there should not be more than two people per bedroom

- children under 5 years old of a different gender can share a bedroom

- children 5 years and older of opposite gender should have separate bedrooms

- children under 18 years of age and the same gender can share a bedroom

- single adults 18 years and older should have separate bedrooms, as well as any coupled adults 18 years and older and parents (ABS 2016a; Mallett, Bentley et al. 2011).

Area-based dimensions

To measure neighbourhood socio-economic status (SES), the ABS Socio-Economic Indexes for Areas (SEIFA) index of relative socio-economic advantage/disadvantage is employed.

The SEIFA index represents a continuum from advantage to disadvantage, which takes into consideration factors such as share of families with high income, tertiary education and in skilled occupations. A lower score in the index represents a more disadvantaged area, while a higher score represents a more advantaged area, with the score ranging from 445.2 to 1222.9 (ABS 2018).

1 Equivalised household income is generated by dividing the unequivalised income of each household by a factor from the OECD modified equivalence scale. Thus, the first adult is allocated 1 point, with a further 0.5 points allocated for every additional individual aged 15 years or older, and 0.3 for each child under 15 years old (ABS 2016b). 
We reverse score the SEIFA index to achieve consistency with the other neighbourhood variables, so that a low score on the reverse-scored SEIFA index represents high-neighbourhood SES, while a high score represents low-neighbourhood SES.

We also employ the neighbourhood crime and hostility variables in the HILDA survey, which are scored from 1 to 5 , so a neighbourhood incident could be rated as:

1. never happens

2. very rare

3. not common

4. fairly common

5. very common.

We convert this into a binary variable that is equal to one if the underlying neighbourhood variable has a score of 4 or 5 (fairly to very common), and 0 otherwise. ${ }^{2}$

\subsubsection{Wellbeing dimensions}

There are a range of subjective wellbeing measures that can be drawn from the HILDA survey. We do not attempt to model all the wellbeing measures available in HILDA, as some of these measures are highly correlated. For instance, satisfaction with one's community is likely to be highly correlated with satisfaction with the neighbourhood, and satisfaction with one's health is likely to be linked to self-assessed health measures. Overall, we experimented with a range of wellbeing variables, but our final set of selected measures was guided by two criteria:

1. To approach maximum diversity in terms of the breadth of dimensions covered. This means avoiding overlaps in measures - for example, keeping satisfaction with feeling part of one's community while omitting satisfaction with one's neighbourhood.

2. To focus on specific wellbeing outcomes that are most likely to vary between those who have experienced precarious housing versus those who have not. The measures that we have selected can be grouped under two broad domains: satisfaction and self-assessed health.

\section{Satisfaction}

There are different questions within the HILDA survey that record an individual's self-evaluation of their satisfaction. We investigate four satisfaction dimensions:

- life satisfaction

- satisfaction with employment opportunities

- satisfaction with finances

- satisfaction with feeling part of community.

These dimensions cover a broad-based evaluation of overall life satisfaction, as well as domains that are particularly affected by housing precariousness:

- ability to access employment

- financial stability

- social connection through attachment to community.

Each of these satisfaction variables is scored on a scale from 0-10, with 0 representing totally dissatisfied, 5 neither satisfied nor dissatisfied and 10 totally satisfied.

2 While the crime and hostility neighbourhood variables are available every wave from waves 1 to 4 , they are only available in every two waves from Wave 4 onwards. To address these data gaps, a missing observation in a wave is replaced with its value for the same respondent from the previous wave. 


\section{SF-36 health}

The SF-36 variables within the HILDA survey are employed as another way of measuring a respondent's wellbeing, focussing on self-assessed health. The SF-36 measure is a popular measure of various aspects of self-assessed health within the literature.

SF-36 variables are drawn from a short-form health survey containing 36 different questions about health. Each of the SF-36 variables is measured on a scale of 0-100, with higher scores representing better wellbeing (Ware 2000). This SF-36 measure has been deployed in various studies within the housing literature, including Baker, Bentley et al. (2013), Baker, Mason et al. (2014) and Bentley, Baker et al. (2011). We specifically investigate the self-assessed mental health and physical functioning of respondents in order to capture both mental health and physical health.

\subsubsection{Precarious housing and wellbeing index construction}

A principal component analysis (PCA) methodology, a dimensionality reduction technique, is applied to construct both a precarious housing index and a wellbeing index. In particular, the PCA technique is widely used where there are a number of closely related variables and the researcher or analyst wants to allow the most significant influences from these variables to remain after the index is constructed. The PCA technique is particularly useful when the variables under consideration are related, so that if there are $k$ variables, the PCA will transform these into a reduced amount of $p$ new uncorrelated variables (Brooks 2014). In the present context, PCA allows for separate factors to be combined into one measure, allowing for a holistic examination of an individual's overall housing precariousness or wellbeing.

The index of precarious housing is constructed by combining the following variables, which are then SEIFA reverse scored:

- forced moves

- unaffordable housing

- overcrowding

- neighbourhood crime

- neighbourhood hostility.

The wellbeing index is constructed from the following variables:

- satisfaction with life

- satisfaction with finances

- satisfaction with employment opportunities

- satisfaction with community

- mental health

- physical functioning.

We also use a PCA methodology to construct a wellbeing index that incorporates each of the above dimensions to provide a holistic examination of wellbeing. 


\subsubsection{Defining the "precariously housed'}

The precariously housed are defined as those with a high precarious housing index-that is, those with a precarious housing index score that is greater than the 75th percentile threshold of the index distribution. The minimum and maximum possible values of the precarious housing index distribution are 0 and 6 respectively. The 75th percentile of the index distribution has an index score of 1.36. Because 25 per cent of the total sample have an index greater than the 75th percentile of the index distribution, the same proportion is defined as being precariously housed.

This approach of converting a continuous measure into a discrete measure representing two groups is typical in housing research for differentiating between those experiencing a particular housing 'stress' condition versus those not experiencing it. For instance, the housing cost-to-income ratio (a continuous measure) is often turned into a discrete measure. This discrete measure differentiates between persons not in housing stress if the ratio exceeds 30 per cent and income falls in the bottom 40 per cent of the distribution, versus persons not in housing stress if the ratio is under 30 per cent or income falls above the bottom 40 per cent of the income distribution (see for instance Ong, Pawson et al. 2020; Rowley and Ong 2012; Wood, Ong et al. 2014).

In addition, it is not uncommon for index distributions to be divided into quartiles where the portion of the distribution above the 75th percentile threshold is deemed capture high index values. One such example is the Housing-based Index of Socio-Economic Status in an epidemiology study by Ryu, Juhn et al. (2017), where an index exceeding the 75th percentile threshold is deemed to be the highest. In Zabel (2015), the house price index distribution is analysed at various percentiles, with the highest values captured at the 75th and 90th percentiles.

\subsubsection{Regressions}

We employ panel data modelling to unpack the causal links between different dimensions of housing precariousness and wellbeing.

We begin by deploying fixed effects models to examine the causal flows from housing precariousness to wellbeing, and vice versa (research question 2). The fixed effects estimator removes the bias of unobserved heterogeneity associated with differences between individuals to the extent that this unobserved heterogeneity is constant over time (see for instance, Baker, Bentley et al. 2013; Bentley, Baker et al. 2011). The factors that are omitted from fixed effects models could include personality characteristics, which in turn provide estimates that are not confounded by these differences between persons that may not be accounted for in the model. Furthermore, this allows for stronger causal inferences to be drawn by focussing on changes within individuals only. This is also consistent with the wider literature where the fixed effects specification appears to be the preferred model for analysing wellbeing outcomes (see for example Baker, Bentley et al. 2013; Bentley, Pevalin et al. 2016; Ong, Nguyen et al. 2018).

However, one of the shortcomings of the fixed effects model is that it cannot estimate the effects of a variable that does not vary at the person level because it is time-invariant at the individual level. An example is ethnicity or, in our case, unobserved time-invariant characteristics of rental housing-assistance recipients that distinguish them from non-recipients and are correlated with their wellbeing levels (research question 3). For instance, housing-assistance recipients may suffer greater exposure towards addictions, which are not directly measurable from the HILDA data, but which might nonetheless depress their wellbeing levels relative to non-recipients. In this case, we adopt a random effects hybrid approach proposed by Mundlak (1978), which allows us to capture differences in characteristics between housing-assistance recipients and non-recipients. More details regarding this approach are set out in Section 2.

Furthermore, we apply either ordinary least squares (OLS) or logistic regression analysis, depending on whether our outcome is linear or binary in nature, respectively. For instance, when modelling the impact of housing precariousness on, say, mental health (a continuous score) we apply OLS regression. But when modelling the impact of wellbeing on whether someone is in unaffordable housing (a yes/no indicator), we apply logistic regression, which is well-suited for non-linear models where the outcome is binary. 


\section{Precarious housing and wellbeing: dimensions, timing and housing assistance}

- Singles, households with no children, low-income households, private renters and residents of major cities have lower wellbeing when precariously housed compared to when they are not precariously housed.

- The gap in wellbeing between the precariously housed and the non-precariously housed has widened over time.

- Forced moves and unaffordability have the most obvious detrimental impact on wellbeing. Forced moves result in a decline of 1.6 per cent in the wellbeing index, while unaffordability depresses the wellbeing index by $0.8 \%$. Forced moves and unaffordability also depress the mental health score by 1.7 per cent and 0.5 per cent, respectively.

- Forced moves, unaffordability and neighbourhood hostility affect a greater range of wellbeing dimensions than other forms of housing precariousness.

- Satisfaction with finances is negatively impacted by forced moves (3.4\% decline) and unaffordable housing ( $2 \%$ decline).

- Satisfaction with the community is negatively impacted by neighbourhood hostility ( $0.7 \%$ decline for each unit increase in the hostility score).

- The receipt of housing assistance does not have a statistically significant impact on the wellbeing of precariously housed renters. 
- Young people are more likely to fall into or remain in precarious housing than older people. Among the 25-34-years age band, 19 per cent fall into precarious housing and 24 per cent stay in precarious housing from year to year. On the other hand, only 4 per cent of the 65+ years age group fall into precarious housing and just 12 per cent stay in precarious housing from year to year.

- The experience of physical violence is a key driver that precipitates a fall into precarious housing or extends a spell of precarious housing. Twenty-two per cent of those who suffered physical violence while not precariously housed in the past year fall into precarious housing in the following year. Three-quarters of victims of physical violence who were in precarious housing in the past year find themselves unable to escape into stable housing by the following year.

This section documents key findings from the report's analysis. We begin by summarising existing research in Section 2.1. Section 2.2 reports how trends in housing precariousness and wellbeing have changed over time from 2002 to 2018. In addition, this section highlights the statistical associations between a range of housing precariousness and wellbeing dimensions, and detects how these associations vary by population subgroups. Sections 2.3 and 2.4 report model findings that unpack the bi-directional links between housing precariousness and wellbeing when potentially confounding factors are controlled for. We highlight which dimensions of precariousness have the greatest impacts on wellbeing, and vice versa. Section 2.5 delves into the role of housing assistance, by shedding light on the extent to which CRA and public housing might cushion the wellbeing of precariously housed renters. Finally, Section 2.6 detects the timing of precarious housing experiences, so as to offer insights into how policy interventions can be appropriately timed to minimise the negative impacts of precarious housing on wellbeing.

\subsection{Existing research}

Against the backdrop of the wider literature, there exist a number of AHURI studies that have contributed to highlighting important and foundational links between housing and wellbeing. Two of these studies have focussed on home owners suffering from housing precariousness.

Wood, Smith et al. (2013) showed that those who leave or churn in and out of ownership suffer from lower wellbeing than ongoing owners, perhaps reflecting the build-up of financial pressure among the precariously housed. Ong, Wood et al. (2019) showed that the difficulty of meeting mortgage repayments depresses older mortgagors' mental health. A third study has focussed on low-income renters. Parkinson, Ong et al. (2014) found that remaining in a disadvantaged area for consecutive years lowers mental wellbeing. The study also found that moves away from the most disadvantaged areas improve private renters' wellbeing.

However, there remain some gaps in the AHURI evidence-base, which the current report aims to fill. Firstly, the annual update of the HILDA survey offers an important opportunity to update existing findings on the links between housing and wellbeing. For instance, Wood, Smith et al. (2013) and Parkinson, Ong et al. (2014) report findings that are now a decade old. Secondly, most studies focus on mental health measures, so the analysis in this report widens the evidence-base by examining a range of wellbeing outcomes that span both health and satisfaction domains. Overall, this report aims to pull together a more integrated evidence-base than previous AHURI research by examining the links across a myriad of precarious housing and wellbeing dimensions over the same timeframe (2002-2018).

Hence, this report's findings will extend past housing and wellbeing studies to generate a coherent and compelling evidence-base that offers an up-to-date national picture on the links between precarious housing, housing assistance and wellbeing. 


\subsection{Precarious housing and wellbeing over time}

We begin by profiling the average trends in precarious housing and wellbeing over time, from 2002 to 2018. Figure 1 displays the mean values of the overall precarious housing index, as well as various precarious housing dimensions. The left-hand panel shows that, overall, the average level of precarious housing has fallen over time, with the mean precarious housing index declining from 1.14 to 1.05 over the 17 years. This is equivalent to roughly a 9 per cent decline in the index from its initial value of 1.14 at the beginning of the timeframe. However, it is worth noting that the spread of the index is wide, ranging from a minimum of 0 to a maximum of 6 . The index is also a composite of multiple precariousness dimensions, which are unpacked more in the middle and right-hand panels of the figure.

In the middle panel, the prevalence of forced moves, unaffordable housing and overcrowding is described over time. Two observations are key:

- First, unaffordable housing - ranging from an average incidence of 6 per cent to 8 per cent over the study timeframe-is a more common form of housing precariousness than forced moves and overcrowding, which average around 3 per cent of the sample.

- Second, the share of the sample in unaffordable housing has risen noticeably over time, from 6 per cent in 2002, peaking at around 8 per cent in 2010 and stabilising at 7-8 per cent since.

The right-hand panel describes trends in area-level or neighbourhood-level precariousness. The mean neighbourhood crime and hostility scores, average at around 2 out of a maximum of 5 , and suggest that on average neighbourhood crime and hostility is not very common. The SEIFA score, however, has remained consistently at around 2.2 on average. Average neighbourhood crime scores have been on a downward trend over time. In fact, the overall downward trend in mean housing precariousness is largely attributable to the downward trend in neighbourhood crime.

Figure 2 displays the mean wellbeing index, as well as the mean satisfaction and SF-36 health scores. Despite the fall in the overall precarious housing index, the average wellbeing index has remained fairly constant at around 4.6-4.7 over the 17 years. However, there are some distinct differences across wellbeing dimensions. Among the four satisfaction domains, the HILDA survey respondents tend to be most satisfied with their life overall but least satisfied with their finances. However, while the average life satisfaction and community satisfaction scores of the respondents have remained roughly constant at around 8 and 6.5 respectively over time, the score has risen noticeably from 5.9 to 6.6 in the area of satisfaction with finances-a 12 per cent increase from the 2002 value. On the other hand, in the self-assessed health domain, the average scores for mental and physical health have both fallen slightly over time.

Figure 1: Trends in mean precarious housing scores, 2002-2018
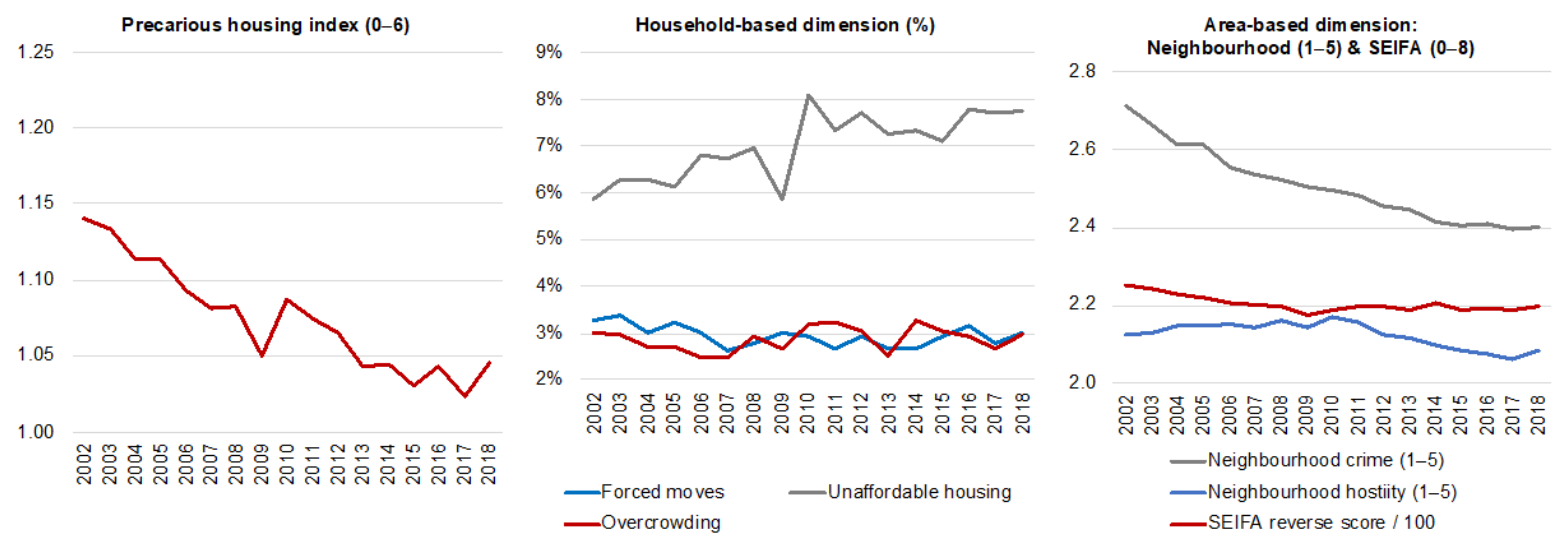

Note: a. Minimum and maximum possible values are reported in parentheses.

Source: HILDA survey 2002-2018. 
Figure 2: Trends in mean wellbeing scores, 2002-2018
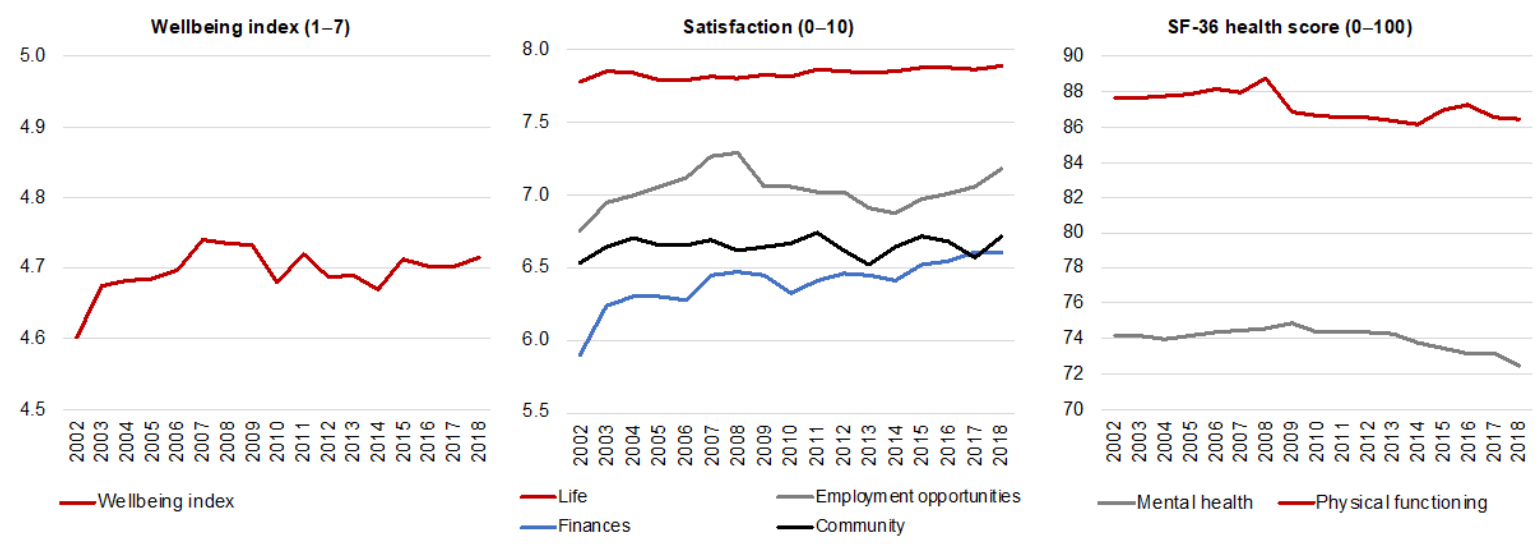

Note: a. Minimum and maximum possible values are reported in parentheses.

Source: HILDA survey 2002-2018.

Table 1 begins unpacking the relationship between different dimensions of housing precariousness and wellbeing outcomes. Specifically, the table reports the mean wellbeing outcomes of those who experience each form of housing precariousness versus those who do not. Wellbeing and precariousness housing characteristics are compared contemporaneously. Each ratio is derived by taking the mean wellbeing score experienced by those suffering a form of precariousness (e.g. forced to move) and dividing it by the mean wellbeing score experienced by those not suffering the same form of precariousness (e.g. not forced to move).

All the ratios are less than 100 per cent, indicating that on average those experiencing housing precariousness will report lower wellbeing scores than those not experiencing housing precariousness. The gap in wellbeing between those in precariousness versus those not in precariousness is most obvious in the domain of satisfaction with finances. This applies to the following precariousness domains-forced moves, unaffordable housing, overcrowding and high-crime neighbourhood. It is also evident that when comparing those with a high precariousness index versus those with a mid-to-low precariousness index, the gap in wellbeing is greatest in the area of financial satisfaction, where the mean financial satisfaction score of those with a high precariousness index is just 85 per cent of those with a mid-to-low precariousness index.

There are two exceptions. The wellbeing gap is greatest in the area of satisfaction with one's community when comparing those living in hostile neighbourhoods versus those not in hostile neighbourhoods (85\%). This finding is unsurprising, as neighbourhoods with hostile residents are likely to strain the social fabric of the local community and weaken community ties. Also, the wellbeing gap is greatest in the area of satisfaction with employment opportunities when comparing those who live in low-SES neighbourhoods versus those in high-SES neighbourhoods, as low-area SES is likely correlated with poor access to job opportunities (90\%). 
2. Precarious housing and

wellbeing: dimensions, timing

and housing assistance

Table 1: Mean wellbeing score, by precarious housing dimension, 2002-2018

\begin{tabular}{|c|c|c|c|c|c|c|}
\hline & \multicolumn{4}{|c|}{$\begin{array}{l}\text { Satisfaction } \\
\quad(0-10)\end{array}$} & \multicolumn{2}{|c|}{$\begin{array}{l}\text { SF-36 health score } \\
(0-100)\end{array}$} \\
\hline & Life & $\begin{array}{l}\text { Employment } \\
\text { opportunities }\end{array}$ & Finances & Community & Mental health & $\begin{array}{r}\text { Physical } \\
\text { functioning }\end{array}$ \\
\hline \multicolumn{7}{|l|}{ Forced move } \\
\hline No & 7.8 & 7.1 & 6.5 & 6.7 & 74.3 & 87.1 \\
\hline Yes & 7.5 & 6.6 & 5.3 & 5.9 & 68.4 & 86.2 \\
\hline Ratio (Yes:No) & $96.2 \%$ & $93.0 \%$ & $81.5 \%$ & $88.1 \%$ & $96.2 \%$ & $99.0 \%$ \\
\hline \multicolumn{7}{|c|}{ Unaffordable housing } \\
\hline No & 7.9 & 7.1 & 6.5 & 6.7 & 74.5 & 87.3 \\
\hline Yes & 7.5 & 6.3 & 5.3 & 6.2 & 69.2 & 84.1 \\
\hline Ratio (Yes:No) & $94.9 \%$ & $88.7 \%$ & $81.5 \%$ & $92.5 \%$ & $96.2 \%$ & $96.3 \%$ \\
\hline \multicolumn{7}{|l|}{ Overcrowding } \\
\hline No & 7.8 & 7.1 & 6.5 & 6.7 & 74.2 & 87.2 \\
\hline Yes & 7.6 & 6.4 & 5.6 & 6.4 & 70.5 & 83.8 \\
\hline Ratio (Yes:No) & $97.4 \%$ & $90.1 \%$ & $86.2 \%$ & $95.5 \%$ & $96.2 \%$ & $96.1 \%$ \\
\hline \multicolumn{7}{|c|}{ Hostile neighbourhood (hostility fairly or very common) } \\
\hline No & 7.9 & 7.1 & 6.5 & 6.8 & 74.9 & 87.5 \\
\hline Yes & 7.4 & 6.3 & 5.6 & 5.8 & 66.2 & 82.6 \\
\hline Ratio (Yes:No) & $93.7 \%$ & $88.7 \%$ & $86.2 \%$ & $85.3 \%$ & $96.2 \%$ & $94.4 \%$ \\
\hline \multicolumn{7}{|c|}{ High-crime neighbourhood (crime fairly or very common) } \\
\hline No & 7.9 & 7.1 & 6.6 & 6.8 & 75.1 & 87.4 \\
\hline Yes & 7.6 & 6.6 & 5.9 & 6.2 & 69.9 & 84.7 \\
\hline Ratio (Yes:No) & $96.2 \%$ & $93.0 \%$ & $89.4 \%$ & $91.2 \%$ & $96.2 \%$ & $96.9 \%$ \\
\hline \multicolumn{7}{|c|}{ Low-neighbourhood SES (SEIFA score in the bottom $20 \%$ of the score distribution) } \\
\hline No & 7.9 & 7.2 & 6.5 & 6.7 & 74.7 & 88.1 \\
\hline Yes & 7.7 & 6.5 & 6 & 6.4 & 71.2 & 82 \\
\hline Ratio (Yes:No) & $97.5 \%$ & $90.3 \%$ & $92.3 \%$ & $95.5 \%$ & $96.2 \%$ & $93.1 \%$ \\
\hline \multicolumn{7}{|c|}{ High precariousness index (index >=75th percentile of index distribution) } \\
\hline No & 7.97 & 7.24 & 6.73 & 6.91 & 76.09 & 88.15 \\
\hline Yes & 7.54 & 6.54 & 5.75 & 6.17 & 69.26 & 84.3 \\
\hline Ratio (Yes:No) & $94.6 \%$ & $90.3 \%$ & $85.4 \%$ & $89.3 \%$ & $96.2 \%$ & $95.6 \%$ \\
\hline All & 7.8 & 7.0 & 6.4 & 6.7 & 74.1 & 87 \\
\hline
\end{tabular}

Source: HILDA survey 2002-2018. 
Table 2 shows that among those who are precariously housed, sole parents, singles, low-income households and public renters are most likely to report low-wellbeing scores, with 52 per cent, 45 per cent, 47 per cent and 60 per cent reporting low-wellbeing index scores respectively. These groups are likely to be the most financially constrained; sole parents and singles do not enjoy the economies of scale in consumption that larger households do, while low-income and public-housing households are obviously financially disadvantaged groups.

However, further interesting differences emerge when comparing those who are precariously housed versus those who are not precariously housed within each subgroup. A 'low-wellbeing' gap can be derived by deducting the share with a low-wellbeing index in the non-precariously housed group from the share with a low-wellbeing index in the 'precariously housed' group. The positive percentage point gap measure across all population subgroups in the table indicate that the share of respondents with low wellbeing is greater among the precariously housed than those not precariously housed within each subgroup.

When comparing differences in the shares with low wellbeing within each household type, we find the "lowwellbeing' gap is greater among those with no children (18-19 percentage points) than those with children (14-16 percentage points).

When assessing differences in the shares with low wellbeing within each income group, the 'low-wellbeing' gap is greatest among low-income households at 16 percentage points, narrowing to 14 percentage points among medium-income households, and then to 11 percentage points among high-income households. The pattern suggests that high-income households who find themselves in precarious housing are better able to make adjustments to buffer their wellbeing than low-income households, who are typically more financially constrained.

The 'low-wellbeing' gap is also greatest among private renters at 18 percentage points among all housing tenure types. The finding is not surprising; home owners and public renters enjoy greater tenure security that likely cushions their wellbeing levels when exposed to precarious housing circumstances.

The 'low-wellbeing' gap between the precariously housed and non-precariously housed is greater in major cities, where affordability pressures tend to be greater than regional areas. It would also appear that the 'low-wellbeing gap' between the precariously housed and the non-precariously housed has widened over time.

Overall, Table 2 suggests that households with no children, low-income households, private renters and residents of major cities are most likely to suffer a drop in wellbeing when precariously housed compared to when these subgroups are not precariously housed. 
Table 2: Share with low wellbeing, precariously housed versus not precariously housed, by population subgroup, 2002-2018

\begin{tabular}{|c|c|c|c|c|}
\hline & & \multicolumn{2}{|c|}{ Share with low wellbeing } & \multirow[b]{2}{*}{$\begin{array}{r}\text { Low-wellbeing } \\
\text { gap }^{2}\end{array}$} \\
\hline \multicolumn{2}{|c|}{ Population and period subgroups } & $\begin{array}{r}\text { Not precariously } \\
\text { housed }\end{array}$ & $\begin{array}{r}\text { Precariously } \\
\text { housed }\end{array}$ & \\
\hline \multirow[t]{4}{*}{ Household type } & Couples with children & $24.7 \%$ & $41.0 \%$ & $16.3 \% \mathrm{pts}$ \\
\hline & Couples no children & $19.1 \%$ & $36.9 \%$ & $17.7 \% \mathrm{pts}$ \\
\hline & Sole parents & $37.3 \%$ & $51.6 \%$ & $14.2 \% \mathrm{pts}$ \\
\hline & Singles & $26.0 \%$ & $44.9 \%$ & $18.8 \% \mathrm{pts}$ \\
\hline \multirow[t]{3}{*}{ Income groups ${ }^{\mathrm{b}}$} & Low income & $30.8 \%$ & $46.8 \%$ & $16.0 \% \mathrm{pts}$ \\
\hline & Medium income & $17.4 \%$ & $31.1 \%$ & $13.7 \% \mathrm{pts}$ \\
\hline & High income & $11.5 \%$ & $22.3 \%$ & $10.8 \% \mathrm{pts}$ \\
\hline \multirow[t]{5}{*}{ Housing tenure } & Outright owner & $15.7 \%$ & $30.0 \%$ & $14.3 \% \mathrm{pts}$ \\
\hline & Mortgage owner & $17.5 \%$ & $31.5 \%$ & $14.0 \% \mathrm{pts}$ \\
\hline & Private renter & $24.2 \%$ & $42.6 \%$ & $18.4 \% \mathrm{pts}$ \\
\hline & Public renter & $48.5 \%$ & $59.7 \%$ & $11.3 \% \mathrm{pts}$ \\
\hline & Other tenure & $23.7 \%$ & $34.1 \%$ & $10.4 \% \mathrm{pts}$ \\
\hline \multirow[t]{2}{*}{ Region } & Regional area & $18.3 \%$ & $35.8 \%$ & $17.5 \% \mathrm{pts}$ \\
\hline & Major city & $18.9 \%$ & $38.2 \%$ & $19.2 \% \mathrm{pts}$ \\
\hline \multirow[t]{3}{*}{ Period } & Pre-GFC (2002-2008) & $19.1 \%$ & $36.4 \%$ & $17.3 \% \mathrm{pts}$ \\
\hline & GFC (2009-2010) & $18.2 \%$ & $36.2 \%$ & $17.9 \% \mathrm{pts}$ \\
\hline & Post-GFC (2011-2018) & $18.6 \%$ & $37.9 \%$ & $19.3 \% \mathrm{pts}$ \\
\hline
\end{tabular}

Notes:

a. Low wellbeing is defined as having a wellbeing index score below the 25th percentile of the wellbeing index distribution. A 'low-wellbeing' gap is derived by deducting the share with a low-wellbeing index in the non-precariously-housed group from the share with a low-wellbeing index in the precariously housed group.

b. Low-income households are in the bottom 40 per cent of the real household equivalised disposable income distribution. Medium-income households are within the 40th and 80th percentiles, and high-income households are in the top 20 per cent.

Source: HILDA survey 2002-2018.

\subsection{How does precarious housing affect wellbeing one year later?}

In order to detect causal flows from precarious housing to wellbeing, we estimate a set of models to measure the impact of separate precarious housing indicators on the separate wellbeing outcomes. This is expressed algebraically as follows:

$$
\text { Well }_{i . t+1}=\beta^{*} \operatorname{Prec}_{i t}+\delta^{*} X_{i t}+\Phi_{i}+\varepsilon_{i t}
$$

Where $i$ indexes individuals and $t$ indexes time. $\Phi_{i}$ represents time-invariant characteristics that control for unobserved heterogeneity, such as personality traits, and $\varepsilon_{i t}$ represents a random error term. Well represents an individual's wellbeing score, while Prec represents the precarious housing indicators. $X$ represents a vector of controls that captures socio-demographic and human capital characteristics, geography and calendar years. The controls are defined and listed in appendix Table A1. 
As wellbeing is the outcome of interest, the wellbeing outcomes at time $t+1$ are matched with the precarious housing predictors at time $t$. The approach aims to alleviate potential endogeneity concerns due to reverse causation by matching precarious housing predictors observed in a wave with wellbeing outcomes a wave later.

A total of seven models are executed, each of six accounting for one separate wellbeing outcome-life satisfaction, satisfaction with employment opportunities, satisfaction with finances, satisfaction with one's community, SF-36 mental health, SF-36 physical functioning - plus a final model that models the wellbeing index. We deploy fixed effects OLS models, as the dependent variables are treated as continuous.

Table 3 reports the coefficients attached to the precarious housing predictors from OLS regressions. The full regression results, including the coefficients of the control predictors, are reported in appendix Table A2.

To further explain the table, in the case of binary predictors-unaffordable housing, overcrowding-the coefficient represents the unit change in the wellbeing outcome at $t+1$ that takes place as a result when an individual experiences the housing condition at $t$. For instance, a forced move reduces the wellbeing index by 0.074 points. In the case of continuous predictors - neighbourhood crime, neighbourhood hostility and SEIFA index reverse scored/100-the coefficient represents a unit change in the wellbeing outcome at $t+1$ as a result of a unit change in the precarious housing condition. For instance, every 100 point increase in the SEIFA index reverse scored depresses the wellbeing index by 0.008 points.

In order to facilitate comparability across the different wellbeing dimensions, Figure 3 displays the percentage change for all the statistically significant precarious housing coefficients. As some of the wellbeing outcomes are on different scales, the percentage change estimates allow for greater consistency in comparison across wellbeing outcomes than the coefficients. The percentage change is calculated by taking the coefficient and dividing it by the average score of the wellbeing outcome for the entire sample, which is then multiplied by 100.

From Figure 3, we make the following key observations.

Among all household-based precarious housing conditions, forced moves result in the greatest decline in the overall wellbeing index of $1.6 \%$. In comparison, unaffordability depresses the wellbeing index by 0.8 per cent and overcrowding by $0.4 \%$. At the area level, each unit increase in precariousness in the neighbourhood and SEIFA predictors depresses the wellbeing index by 0.1 to 0.3 per cent (though these are not directly comparable with the binary predictors).

In terms of pervasiveness of impacts, forced moves, unaffordability and neighbourhood hostility each affect five wellbeing dimensions. Other precarious housing conditions affect less than five wellbeing dimensions.

It is clear that the links from precarious housing to wellbeing are greater in the satisfaction domains than in the SF-36 health domains. In particular, satisfaction with finances is obviously negatively impacted by forced moves (3.4\% decline) and unaffordable housing ( $2 \%$ decline). At the same time, satisfaction with the community is negatively impacted by neighbourhood hostility $(0.7 \%$ decline for each unit increase in the hostility score) and the neighbourhood SES (0.6\% decline for each 100-point increase in the SEIFA score).

The links between precarious housing and mental health are less pervasive, but still important. In particular, forced moves and unaffordability depress the mental health score by 1.7 per cent and 0.5 per cent respectively. We find limited evidence of wellbeing impacts in the physical functioning domain.

Overall, it would appear that forced moves and unaffordability have the most obvious detrimental impact on wellbeing. 
Table 3: Effect of housing precariousness at $t$ on wellbeing at $t+1$, fixed effects OLS models, 2002-2018

\begin{tabular}{|c|c|c|c|c|c|c|c|}
\hline Predictors & $\begin{array}{r}\text { Satisfaction } \\
\text { with life }\end{array}$ & $\begin{array}{r}\text { Satisfaction } \\
\text { with } \\
\text { employment } \\
\text { opportunities }\end{array}$ & $\begin{array}{r}\text { Satisfaction } \\
\text { with finances }\end{array}$ & $\begin{array}{l}\text { Satisfaction } \\
\text { with community }\end{array}$ & $\begin{array}{l}\text { Mental } \\
\text { health }\end{array}$ & $\begin{array}{r}\text { Physical } \\
\text { functioning }\end{array}$ & $\begin{array}{r}\text { Wellbeing } \\
\text { index }\end{array}$ \\
\hline \multicolumn{8}{|c|}{ Household precarious housing condition } \\
\hline Forced move & $\begin{array}{r}-0.079 * * * \\
(0.017)\end{array}$ & $\begin{array}{r}-0.095^{\star \star \star} \\
(0.029)\end{array}$ & $\begin{array}{r}-0.216^{\star * *} \\
(0.024)\end{array}$ & $\begin{array}{r}-0.120^{\star \star \star} \\
(0.025)\end{array}$ & $\begin{array}{r}-1.244^{\star \star \star} \\
(0.190)\end{array}$ & $\begin{array}{l}-0.204 \\
(0.235)\end{array}$ & $\begin{array}{r}-0.074^{\star \star \star} \\
(0.008)\end{array}$ \\
\hline Unaffordable housing & $\begin{array}{r}-0.039 \star \star \star \\
(0.012)\end{array}$ & $\begin{array}{r}-0.064^{\star \star \star} \\
(0.023)\end{array}$ & $\begin{array}{r}-0.129^{* * *} \\
(0.018)\end{array}$ & $\begin{array}{l}-0.015 \\
(0.018)\end{array}$ & $\begin{array}{r}-0.395^{\star \star \star} \\
(0.142)\end{array}$ & $\begin{array}{r}-0.331^{\star} \\
(0.175)\end{array}$ & $\begin{array}{r}-0.039^{\star \star \star} \\
(0.007)\end{array}$ \\
\hline Overcrowded & $\begin{array}{l}-0.016 \\
(0.019)\end{array}$ & $\begin{array}{l}-0.047 \\
(0.034)\end{array}$ & $\begin{array}{r}-0.055^{\star *} \\
(0.027)\end{array}$ & $\begin{array}{r}0.013 \\
(0.028)\end{array}$ & $\begin{array}{l}-0.108 \\
(0.220)\end{array}$ & $\begin{array}{l}-0.161 \\
(0.272)\end{array}$ & $\begin{array}{r}-0.021^{* *} \\
(0.010)\end{array}$ \\
\hline \multicolumn{8}{|c|}{ Area precarious housing condition } \\
\hline Neighbourhood crime & $\begin{array}{r}-0.009^{\star \star} \\
(0.004)\end{array}$ & $\begin{array}{r}0.013 \\
(0.008)\end{array}$ & $\begin{array}{r}-0.019^{\star \star \star} \\
(0.006)\end{array}$ & $\begin{array}{r}-0.025^{\star \star \star} \\
(0.006)\end{array}$ & $\begin{array}{l}-0.031 \\
(0.048)\end{array}$ & $\begin{array}{r}0.088 \\
(0.059)\end{array}$ & $\begin{array}{r}-0.006^{\star \star} \\
(0.002)\end{array}$ \\
\hline Neighbourhood hostility & $\begin{array}{r}-0.020^{* * *} \\
(0.004)\end{array}$ & $\begin{array}{r}-0.021^{\star \star \star} \\
(0.008)\end{array}$ & $\begin{array}{r}-0.019^{\star * *} \\
(0.006)\end{array}$ & $\begin{array}{r}-0.044^{\star \star \star} \\
(0.006)\end{array}$ & $\begin{array}{r}-0.138^{* \star *} \\
(0.048)\end{array}$ & $\begin{array}{l}-0.053 \\
(0.059)\end{array}$ & $\begin{array}{r}-0.014^{\star \star \star} \\
(0.002)\end{array}$ \\
\hline $\begin{array}{l}\text { SEIFA Index reverse } \\
\text { scored/100 }\end{array}$ & $\begin{array}{r}-0.018^{\star \star \star} \\
(0.006)\end{array}$ & $\begin{array}{l}-0.020 \\
(0.011)\end{array}$ & $\begin{array}{r}0.027^{\star \star \star} \\
(0.009)\end{array}$ & $\begin{array}{r}-0.043^{\star \star \star} \\
(0.009)\end{array}$ & $\begin{array}{r}0.022 \\
(0.071)\end{array}$ & $\begin{array}{r}-0.417^{\star \star \star} \\
(0.088)\end{array}$ & $\begin{array}{r}-0.008^{\star \star} \\
(0.003)\end{array}$ \\
\hline
\end{tabular}

Notes: ${ }^{* *} p<0.01,{ }^{*} p<0.05,{ }^{*} p<0.1$. Standard errors are reported in parentheses. The full regression findings are reported in appendix Table A2.

Source: HILDA survey 2002-2018.

Figure 3a: Change in wellbeing score at $t+1$ as a result of experiencing a precarious housing condition at $t$, expressed as a percentage of the mean wellbeing score at $t+1,2002-2018$

Household-based precarious housing dimension

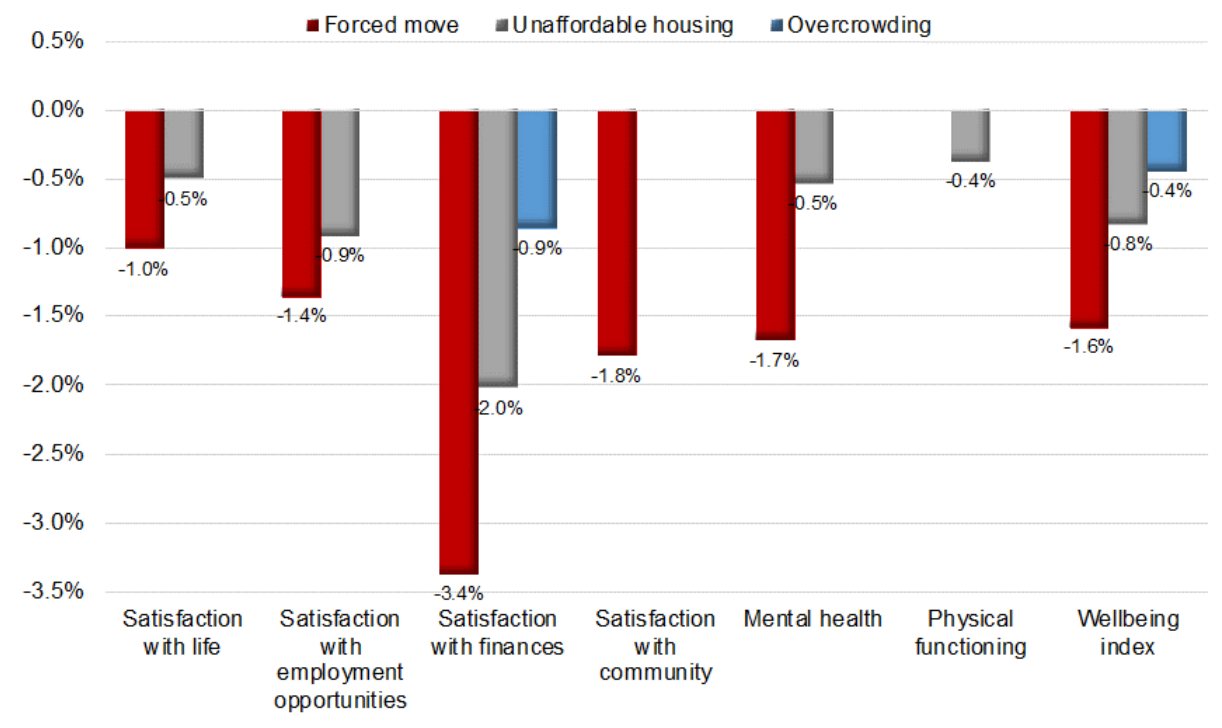


Figure 3b: Change in wellbeing score at $t+1$ as a result of experiencing a precarious housing condition at $t$, expressed as a percentage of the mean wellbeing score at $t+1,2002-2018$

Area-based precarious housing dimension

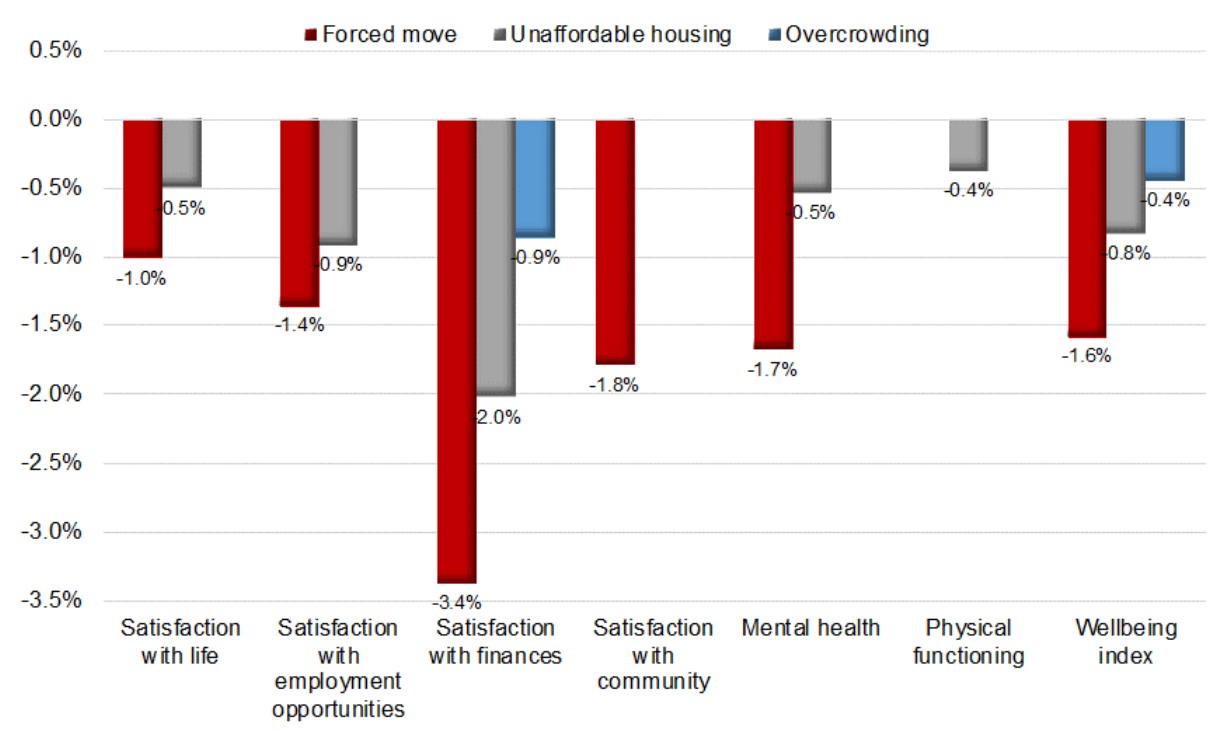

Note: Only statistically significant coefficients are reported. The full regression findings are reported in appendix Table A2. This figure displays both household-based and area-based data.

Source: HILDA survey 2002-2018.

\subsection{How does wellbeing affect precarious housing one year later?}

By estimating the impact of various precarious housing conditions on wellbeing, our results in Section 2.3 allows us to gauge the benefits of implementing policies that address different precarious housing conditions in order to derive wellbeing dividends. Nonetheless, it may be the case that personal wellbeing can impact on precarious housing outcomes. For instance, a person suffering from poor mental health may find it more difficult to sustain an income and therefore fall into housing stress or face eviction from their home. Hence, while secondary in importance to the focus of the report, it is nonetheless useful to investigate the extent to which wellbeing outcomes impact on precarious housing conditions, as they give a glimpse into how health-related policies might have flow-on effects into the housing domain.

The impact of the wellbeing predictors on precarious housing outcomes is estimated in this section. The precarious housing and wellbeing variables are entered into the model separately, resulting in seven models, with each of six addressing one precarious housing outcome and a final model addressing the precarious housing index. The precarious housing indicators are entered at wave $t+1$ and matched with wellbeing at wave $t$ in order to estimate whether wellbeing has an influence on precarious housing a wave later. We estimate both fixed effects logits and fixed effects OLS models, depending on the nature of the outcome variable.

The logit model is applied to household precarious housing outcomes, as these are binary outcomes-that is, forced moves, unaffordability and overcrowding.

The logit models are expressed algebraically as follows:

$$
\operatorname{ProbPrec}_{i t+1}=\frac{1}{1+e^{-\left(\beta^{*} \text { Well }_{i t}+\beta^{*} X_{i t}+\Phi_{i}+\varepsilon_{i}\right)}}
$$


Where ProbPrec Prt $_{i t}$ represents the probability of an individual $i$ at wave $t+1$ experiencing precarious housing. $\beta$ represents the coefficients, while Well represents the wellbeing predictors. Each coefficient from the logit model can be exponentiated to derive an odds ratio. If an odds ratio is greater (less) than 1 , individuals are more (less) likely to experience the precarious housing outcome.

The area precarious housing indicators - neighbourhood crime, neighbourhood hostility and the reverse-scored SEIFA index-are treated as continuous outcomes and therefore estimated using OLS models. The OLS models are expressed algebraically as follows:

$$
\operatorname{Prec}_{i . t+1}=\beta^{*} W e l l_{i t}+\delta^{*} X_{i t}+\Phi_{i}+\varepsilon_{i t}
$$

where Prec represents neighbourhood crime scores, neighbourhood hostility scores and SEIFA reverse-scored index (divided by 100).

In both equations (2) and (3), $\Phi_{i}$ represents time-invariant characteristics that control for unobserved heterogeneity and $\varepsilon_{i t}$ represents a random error term. The control variables are indicated by $X$. These are defined and listed in appendix Table A1.

Table 4 reports the key regression results. The full regression results, including the coefficients of the control predictors, are reported in appendix Table A3.

Focussing on household precarious housing conditions, we find financial satisfaction to be a key influencer of these outcomes. The odds of experiencing a forced move, unaffordable housing and overcrowding are all reduced when financial satisfaction grows. This is particularly evident with respect to unaffordability. With each unit increase in the financial satisfaction score (which runs on a scale of 0 to 10), the odds of experiencing unaffordable housing declines by 6.8 percentage points.

However, when we turn to area precarious housing conditions, we find that satisfaction with one's community results in the greatest reduction in neighbourhood hostility, neighbourhood crime and SEIFA score. While various other wellbeing dimensions are also significant, the magnitude of impact is greatest with respect to one's satisfaction with one's community. However, the magnitudes of impacts of satisfaction with one's community are still small. With each unit increase in satisfaction with one's community (which also runs on a scale of 0 to 10 ), the neighbourhood crime and hostility scores reduce by just under 0.2 points and the SEIFA reversed score reduces by 0.4 points. 
Table 4: Effect of wellbeing at $t$ on housing precariousness at $t+1$, fixed effects logit and OLS models, 2002-2018

\begin{tabular}{|c|c|c|c|c|c|c|}
\hline \multirow[b]{2}{*}{ Predictors } & \multicolumn{3}{|c|}{$\begin{array}{l}\text { Household precarious housing condition: } \\
\text { Logit odds ratio }\end{array}$} & \multicolumn{3}{|c|}{$\begin{array}{l}\text { Area precarious housing condition: } \\
\text { OLS coefficients }\end{array}$} \\
\hline & $\begin{array}{l}\text { Forced } \\
\text { move }\end{array}$ & $\begin{array}{r}\text { Unaffordable } \\
\text { housing }\end{array}$ & Overcrowding & $\begin{array}{r}\text { Neighbourhood } \\
\text { crime }\end{array}$ & $\begin{array}{r}\text { Neighbourhood } \\
\text { hostility }\end{array}$ & $\begin{array}{r}\text { SEIFA } \\
\text { reverse } \\
\text { scored/100 }\end{array}$ \\
\hline Satisfaction with life & $\begin{array}{r}0.951^{\star \star \star} \\
(0.015)\end{array}$ & $\begin{array}{r}1.018 \\
(0.013)\end{array}$ & $\begin{array}{r}0.943^{\star * *} \\
(0.019)\end{array}$ & $\begin{array}{r}-0.007^{\star \star \star} \\
(0.002)\end{array}$ & $\begin{array}{r}-0.010^{\star * *} \\
(0.002)\end{array}$ & $\begin{array}{r}-0.002^{\star} \\
(0.001)\end{array}$ \\
\hline $\begin{array}{l}\text { Satisfaction with employment } \\
\text { opportunities }\end{array}$ & $\begin{array}{r}0.995 \\
(0.010)\end{array}$ & $\begin{array}{r}1.001 \\
(0.008)\end{array}$ & $\begin{array}{r}1.004 \\
(0.012)\end{array}$ & $\begin{array}{r}0.000 \\
(0.001)\end{array}$ & $\begin{array}{r}0.000 \\
(0.001)\end{array}$ & $\begin{array}{l}-0.001 \\
(0.001)\end{array}$ \\
\hline Satisfaction with finance & $\begin{array}{r}0.977^{\star *} \\
(0.010)\end{array}$ & $\begin{array}{r}0.932^{\star * *} \\
(0.008)\end{array}$ & $\begin{array}{r}0.969 * * \\
(0.013)\end{array}$ & $\begin{array}{l}-0.001 \\
(0.001)\end{array}$ & $\begin{array}{l}-0.002 \\
(0.001)\end{array}$ & $\begin{array}{r}0.002^{* *} \\
(0.001)\end{array}$ \\
\hline Satisfaction with community & $\begin{array}{r}0.988 \\
(0.010)\end{array}$ & $\begin{array}{r}0.992 \\
(0.008)\end{array}$ & $\begin{array}{r}0.992 \\
(0.012)\end{array}$ & $\begin{array}{r}-0.017^{\star \star \star} \\
(0.001)\end{array}$ & $\begin{array}{r}-0.018^{\star \star \star} \\
(0.001)\end{array}$ & $\begin{array}{r}-0.004^{\star * \star} \\
(0.001)\end{array}$ \\
\hline Mental health/10 & $\begin{array}{r}0.965^{\star \star \star} \\
(0.013)\end{array}$ & $\begin{array}{r}0.982 \\
(0.011)\end{array}$ & $\begin{array}{r}1.003 \\
(0.018)\end{array}$ & $\begin{array}{r}-0.009^{* * *} \\
(0.002)\end{array}$ & $\begin{array}{r}-0.017^{\star \star \star} \\
(0.002)\end{array}$ & $\begin{array}{r}0.001 \\
(0.001)\end{array}$ \\
\hline Physical functioning/10 & $\begin{array}{r}1.014 \\
(0.012)\end{array}$ & $\begin{array}{r}0.980^{* *} \\
(0.009)\end{array}$ & $\begin{array}{r}1.004 \\
(0.014)\end{array}$ & $\begin{array}{r}-0.003^{\star * \star} \\
(0.001)\end{array}$ & $\begin{array}{r}-0.004^{\star \star} \\
(0.001)\end{array}$ & $\begin{array}{r}-0.003^{\star \star \star} \\
(0.001)\end{array}$ \\
\hline
\end{tabular}

Notes: ${ }^{* *} p<0.01,{ }^{* *} p<0.05,{ }^{*} p<0.1$. Standard errors are reported in parentheses. The full regression findings are reported in appendix Table A3.

Source: HILDA survey 2002-2018.

\subsection{How does housing assistance affect the wellbeing of precariously housed renters?}

In this section, we model the extent to which housing assistance is able to cushion the wellbeing of renters who are precariously housed. We make a distinction between CRA and public-housing programs. The sample is restricted to renters who are precariously housed. As per subsection 1.4.5, we define the precariously housed as those whose precarious housing index is 'high'- that is, it exceeds the 75th percentile of the index.

However, in order to test for the robustness of this measure, we run our models on an alternative definition of being 'precariously housed', where the precariously housed can be defined as those who experience at least one form of precarious housing ${ }^{3}$. We find our model findings to be robust across both definitions. When the second definition is applied, 37 per cent of the sample are found to be precariously housed because they experience at least one form of precarious housing. The two definitions overlap, but in general the first definition is more restrictive and therefore captures a smaller proportion (25\%) of the sample as being precariously housed.

3 This is straightforward with respect to the household-based dimensions, where forced moves, unaffordable housing and overcrowding are all represented by binary indicators. The area-based variables are more continuous in nature. Hence, each area-based value is converted into a binary indicator to determine whether it counts as precarious housing. A respondent is counted as experiencing neighbourhood hostility (or neighbourhood crime) if the variable takes on a value of 4 or 5 (fairly common or very common). The respondent is counted as experiencing low neighbourhood SES if the SEIFA score is in the bottom 20 per cent of the SEIFA distribution. 
We deploy a Mundlak (1978) random effects model to examine this issue. As explained in Section 1, one of the shortcomings of the fixed effects model is that it cannot estimate the effects of a variable that does not vary at the person level because it is time-invariant at the individual level. Some time-invariant characteristics of rental housing-assistance recipients may distinguish them from non-recipients and are correlated with their wellbeing levels, but yet they are unobservable from our data. For instance, housing-assistance recipients may suffer greater exposure towards addictions, which are not directly measurable from the HILDA data, but which might nonetheless depress their wellbeing levels relative to non-recipients. In this case, we adopt a hybrid approach proposed by Mundlak (1978). The model is expressed algebraically as follows:

$$
\boldsymbol{W I}_{j . t+1}=\alpha^{*} \bar{H}_{j}+\boldsymbol{\beta}^{*}\left(H_{j t}-\bar{H}_{j}\right)+\gamma^{*} \boldsymbol{P r e c}_{j t}+\boldsymbol{\delta}^{*} \boldsymbol{X}_{j t}+\boldsymbol{\Phi}_{j}+\boldsymbol{\varepsilon}_{j t}
$$

Where $i$ indexes renters who are precariously housed and $t$ indexes time. $\Phi_{j}$ represents time-invariant characteristics that control for unobserved heterogeneity of precariously housed renters, and $\varepsilon_{j t}$ represents a random error term. WI represents a precariously housed renter's wellbeing index score while Prec represents the precarious housing indicators. $X$, the vector of controls, is described in appendix Table A1.

However, equation (4) is distinct from equations (1) to (3) in that the former contains two additional terms. The unobserved between-person effect is captured by a fixed variable $\bar{H}_{j}$ which represents the mean housing-assistance level $\bar{H}_{j}$ received by person $i$ across all the waves in which the person is observed in the HILDA survey. The withinperson effect is captured by a time-varying variable that represents the deviation of the housing-assistance level at time $t$ from the mean, that is $\left(H_{j}-\bar{H}_{j t}\right)$. This time-varying predictor gives the impact of receipt of housing assistance on wellbeing, as distinct from, which gives the average difference in unobserved characteristics between housing-

assistance recipients compared to non-recipients.

Table 5 reports the key regression results from estimation of the random effects Mundlak model, equation (4). The full regression results, including the coefficients of the control predictors, are reported in appendix Table A3.

The key emphasis of this section is on whether housing assistance improves the wellbeing outcomes of precariously housed renters. Results from estimation of the random effects model indicate the $\bar{H}_{j}$ predictor is negative and statistically significant in the case of both CRA and public housing. The results suggest that precariously housed CRA recipients and public-housing tenants have wellbeing index scores that are on average lower than precariously housed renters not in receipt of housing assistance. This finding is evident despite controls for characteristics such as age, the presence of young children, and labour-market history-all personal characteristics that we know are likely to influence housing-assistance status. It is therefore likely that the negative coefficients of $H_{j}$ capture the impact of unobservables that are correlated with both housing-assistance eligibility and wellbeing outcomes. Turning to the $\left(H_{j}-\bar{H}_{j t}\right)$ estimates reported in the table, we find these coefficients to be all statistically insignificant, regardless of whether the housing-assistance program of interest is CRA or public housing, and irrespective of the definition of being precariously housed.

Results from these specifications indicate that unmeasured differences exist between housing-assistance recipients and non-recipients as per the statistically significant negative coefficient on $H_{j}$, and that the unmeasured differences depress the wellbeing scores of housing-assistance recipients relative to non-recipients. However, once we account for these unmeasured characteristics, our estimates suggest that the receipt of housing assistance does not improve (or depress) wellbeing levels. 
Table 5: Effect of housing assistance at $\mathrm{t}$ on overall wellbeing at $\mathrm{t}+1$ of renters in precarious housing, random effects OLS models, 2002-2018

\begin{tabular}{|c|c|c|}
\hline & $\begin{array}{r}\text { High precarious } \\
\text { housing index }\end{array}$ & $\begin{array}{r}\text { One or more forms of } \\
\text { housing precariousness }\end{array}$ \\
\hline CRA indicator deviation from the mean & $\begin{array}{l}-0.016 \\
(0.017)\end{array}$ & $\begin{array}{l}-0.015 \\
(0.014)\end{array}$ \\
\hline CRA indicator mean & $\begin{array}{r}-0.433^{\star * \star} \\
(0.035)\end{array}$ & $\begin{array}{r}-0.439^{\star \star \star} \\
(0.031)\end{array}$ \\
\hline Public housing indicator deviation from the mean & $\begin{array}{r}0.014 \\
(0.035)\end{array}$ & $\begin{array}{r}0.010 \\
(0.029)\end{array}$ \\
\hline Public housing indicator mean & $\begin{array}{r}-0.540^{\star \star \star} \\
(0.048)\end{array}$ & $\begin{array}{r}-0.498^{\star \star \star} \\
(0.042)\end{array}$ \\
\hline Forced move & $\begin{array}{r}-0.069^{* * *} \\
(0.017)\end{array}$ & $\begin{array}{r}-0.074^{\star * *} \\
(0.015)\end{array}$ \\
\hline Unaffordable housing & $\begin{array}{r}-0.028^{\star} \\
(0.016)\end{array}$ & $\begin{array}{l}-0.011 \\
(0.014)\end{array}$ \\
\hline Overcrowded & $\begin{array}{r}0.009 \\
(0.022)\end{array}$ & $\begin{array}{l}-0.007 \\
(0.019)\end{array}$ \\
\hline Neighbourhood crime & $\begin{array}{r}-0.040^{\star \star \star} \\
(0.008)\end{array}$ & $\begin{array}{r}-0.030 * \star \star \\
(0.006)\end{array}$ \\
\hline Neighbourhood hostility & $\begin{array}{r}-0.021^{* * *} \\
(0.008)\end{array}$ & $\begin{array}{r}-0.027^{\star \star \star} \\
(0.006)\end{array}$ \\
\hline SEIFA index reverse score/100 & $\begin{array}{r}-0.022^{\star \star \star} \\
(0.008)\end{array}$ & $\begin{array}{r}-0.023^{\star * \star} \\
(0.007)\end{array}$ \\
\hline
\end{tabular}

Notes: ${ }^{* *} p<0.01,{ }^{* *} p<0.05,{ }^{*} p<0.1$. Standard errors are reported in parentheses. The full regression findings are reported in appendix Table A4.

Source: HILDA survey 2002-2018

\subsection{The timing of precarious housing experiences}

Based on our modelling results in previous sections, we know that housing precariousness has a negative impact on wellbeing. Furthermore, it is possible for an individual to experience multiple forms of housing precariousness at a time-and this too will have a negative impact on wellbeing. In fact, we find that average wellbeing scores decrease monotonically as individuals experiences multiple forms of precariousness.

Given this, we begin by examining the consecutive transitions in precarious housing - that is, the number of individuals moving from 0 forms of housing precariousness (at time $t$ ) to 1 form of housing precariousness (at time $t+1$ ) and, similarly, individuals transitioning from 1 form (at time $t$ ) to 2 forms (at time $t+1$ ) and so on. With each consecutive transition, we also measure the difference in average wellbeing. For example, what is the average change in wellbeing moving from 0 forms of housing precariousness (at time $t$ ) to 1 form of housing precariousness (at time $t+1$ ) and so on. This provides us with an idea for where the greatest negative impact is in terms of wellbeing. This analysis was carried out for the entire sample of private renters, as well as for low-income households.

The results are as expected, in that the average wellbeing decreases as individuals transition to higher levels of housing precariousness. The greatest decrease occurs when individuals transition from 0 forms of precariousness (at time $t$ ) to 1 form of precariousness (at time $t+1$ ). We observed that there is a 2 per cent to 2.3 per cent decrease in the average wellbeing index. This is consistent across both segments-private renters and low-income households. 
Given this result, the appropriate timing of interventions should occur when individuals transition from 0 forms of housing precariousness to 1 form of housing precariousness. This represents the greatest decrease in wellbeing and may lead to further decreases in wellbeing if the individual faces multiple forms of housing precariousness in the future. The results also highlight the importance of prevention measures that prevent any falls into precarious housing in the first place.

Against this background, we investigate the timing of precarious housing experiences in the next subsections by highlighting key life-course stages that are correlated with experiences of precarious housing. The findings offer insights into how policies and programs can be appropriately timed to prevent or alleviate precarious housing experiences and their wellbeing impacts.

\subsubsection{Precarious housing experiences across the life course}

In this subsection, we divide our sample into four subgroups that record their precarious housing dynamics across adjacent waves of the HILDA survey. These groups are those who:

- fall into precarious housing between $t$ and $t+1$

- escape precarious housing between $t$ and $t+1$

- remain in precarious housing between $t$ and $t+1$

- $\quad$ stay out of precarious housing between $t$ and $t+1$.

The four groups are mutually exclusive.

As per the previous sections, the 'precariously housed' are defined as those with a high precarious housing index-that is, those with a precarious housing index that is greater than the 75th percentile threshold of the index distribution. Thus, a person falls into precarious housing when the individual's precarious housing index switches from below the 75th percentile to above the 75th percentile. Similarly, a person escapes precarious housing when the individual's precarious housing index switches from above to below the 75th percentile.

Overall, the majority of the sample (62\%) are able to stay out of precarious housing between adjacent waves. Just under one-fifth (18\%) stay in precarious housing and 12 per cent are able to escape precarious housing, while a minority (5\%) fall into precarious housing between $t$ and $t+1$.

However, as shown in Figure 4, the young are most likely to fall into or remain in precarious housing, while the old are most likely to escape or stay out of precarious housing. For instance, among the 25-34 years age band, 19 per cent fell into precarious housing between $t$ and $t+1$ and 24 per cent stayed in precarious housing across adjacent waves. On the other hand, only 4 per cent of the 65+ years age group fell into precarious housing and just 12 per cent stayed in precarious housing. Conversely, three-quarters of the 65+years age group are able to stay out of precarious housing across adjacent waves while only half of the 25-34 years age group are able to do so. 
Figure 4: Movements in and out of a precariously housed status, by age band, 2002-2018

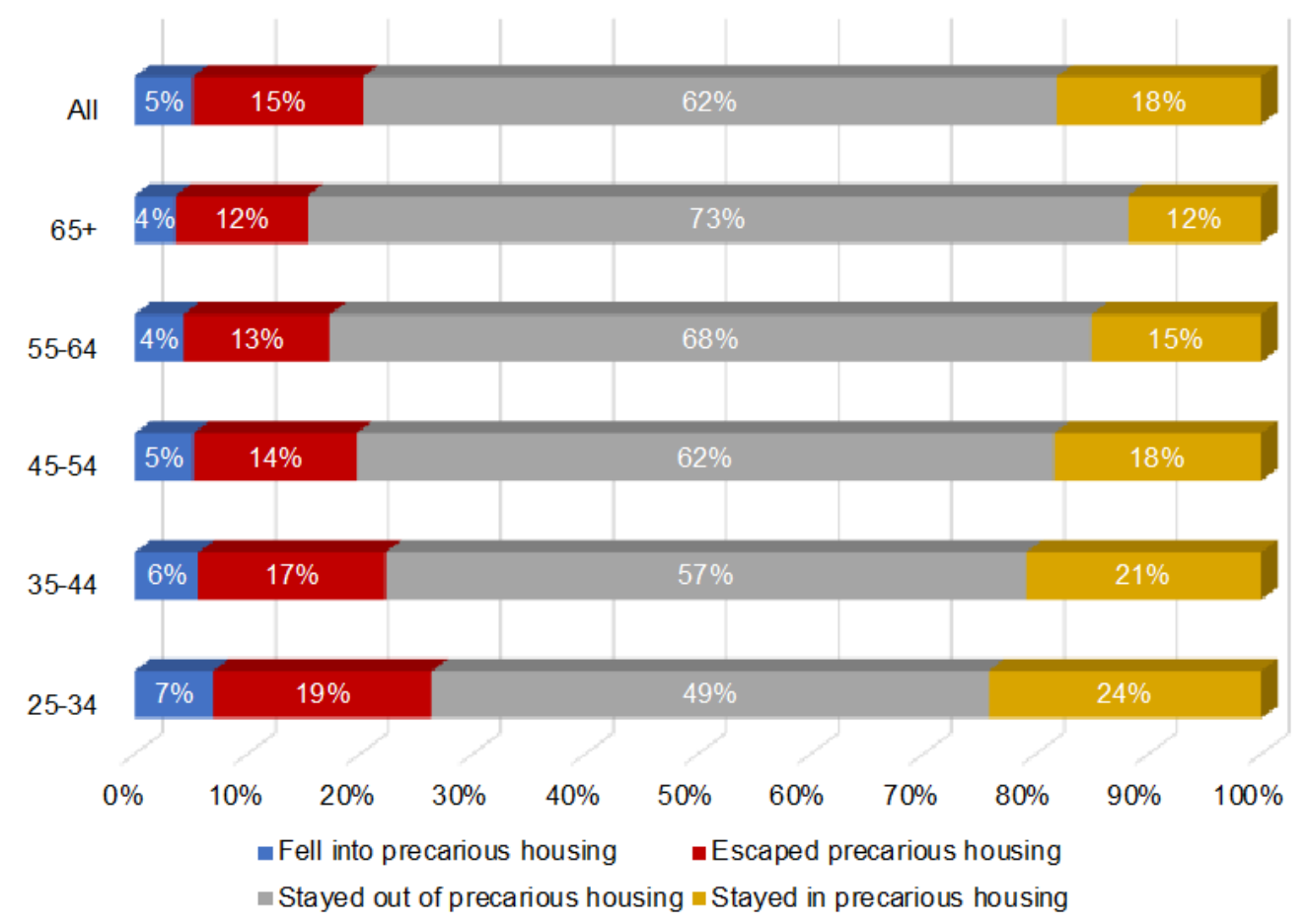

Source: HILDA survey 2002-2018.

We turn next to investigate major events over the life course that are most likely to precipitate a fall into precarious housing and those that tend to extend the length of time spent in precarious housing.

Figure 5 is based on a sample of those who are not precariously housed-that is, respondents in each person-period whose precarious housing index was below the 75th percentile threshold. We then analyse the share of each major life-event group within the non-precariously housed group that fall into precarious housing by $t+1$. Among all who are not precariously housed at $t, 8$ per cent fall into precarious housing between $t$ and $t+1$. However, this incidence of transition into precarious housing is higher among most subgroups that have experienced a major life event in the year leading up to $t$. Most noticeably, 22 per cent of those who suffered physical violence while not precariously housed in the past year fall into precarious housing in the following year. A similar proportion who were detained in jail at some point fall into precarious housing in the following year.

Changes in marital status are also key precipitators of transitions into precarious housing. Among those who either separated or got back together with their spouse in the past year, just under 20 per cent fall into precarious housing by the following year. Other important major life events that precipitate a shift from stable housing into precarious housing are a major worsening of finances, a change in residence, experiencing a property crime and having a close family member detained in jail. 
Figure 5: Share of those not precariously housed at $\mathrm{t}$ who fall into precarious housing between $t$ and $t+1$, by major life event, 2002-2008

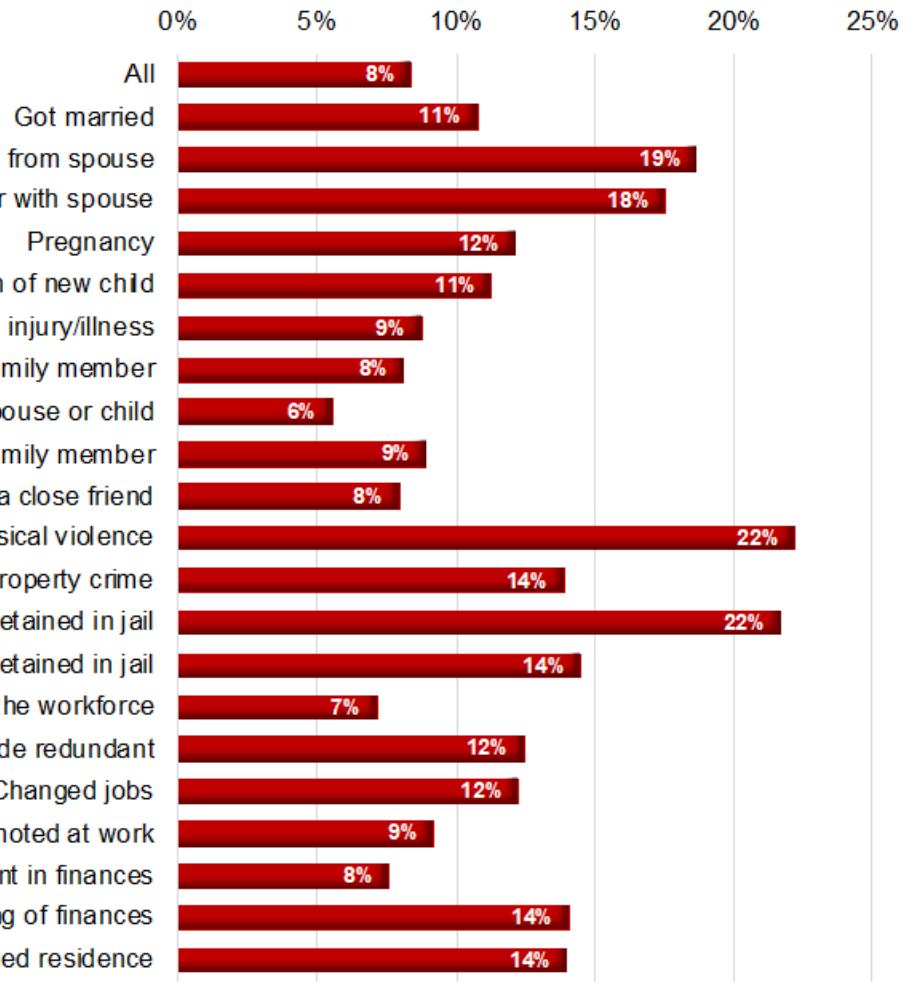

Source: HILDA survey 2002-2018.

Figure 6 is based on a sample of the precariously housed at $t$. We then analyse the share of each major life-event group within the precariously housed who remain in precarious housing between $t$ and $t+1$. Among those who are precariously housed, 55 per cent are still in precarious housing in the next year. Once again, the experience of physical violence is one of the most important factors that can prolong a spell in precarious housing. Specifically, three-quarters of victims of physical violence who were already in precarious housing at $t$ find themselves unable to escape into stable housing by $t+1$. A similar proportion who were detained in jail at some point while precariously housed will remain in precarious housing in the following year.

Property crime, jail detention of a close family member and a major worsening of finances are also key drivers that prolong stays in precarious housing, with approximately 70 per cent of these groups who were already in precarious housing in the past year finding themselves still in precarious housing the following year. 
Figure 6: Share of the precariously housed at $\mathrm{t}$ who remain in precarious housing between $t$ and $t+1$, by major life event, 2002-2008

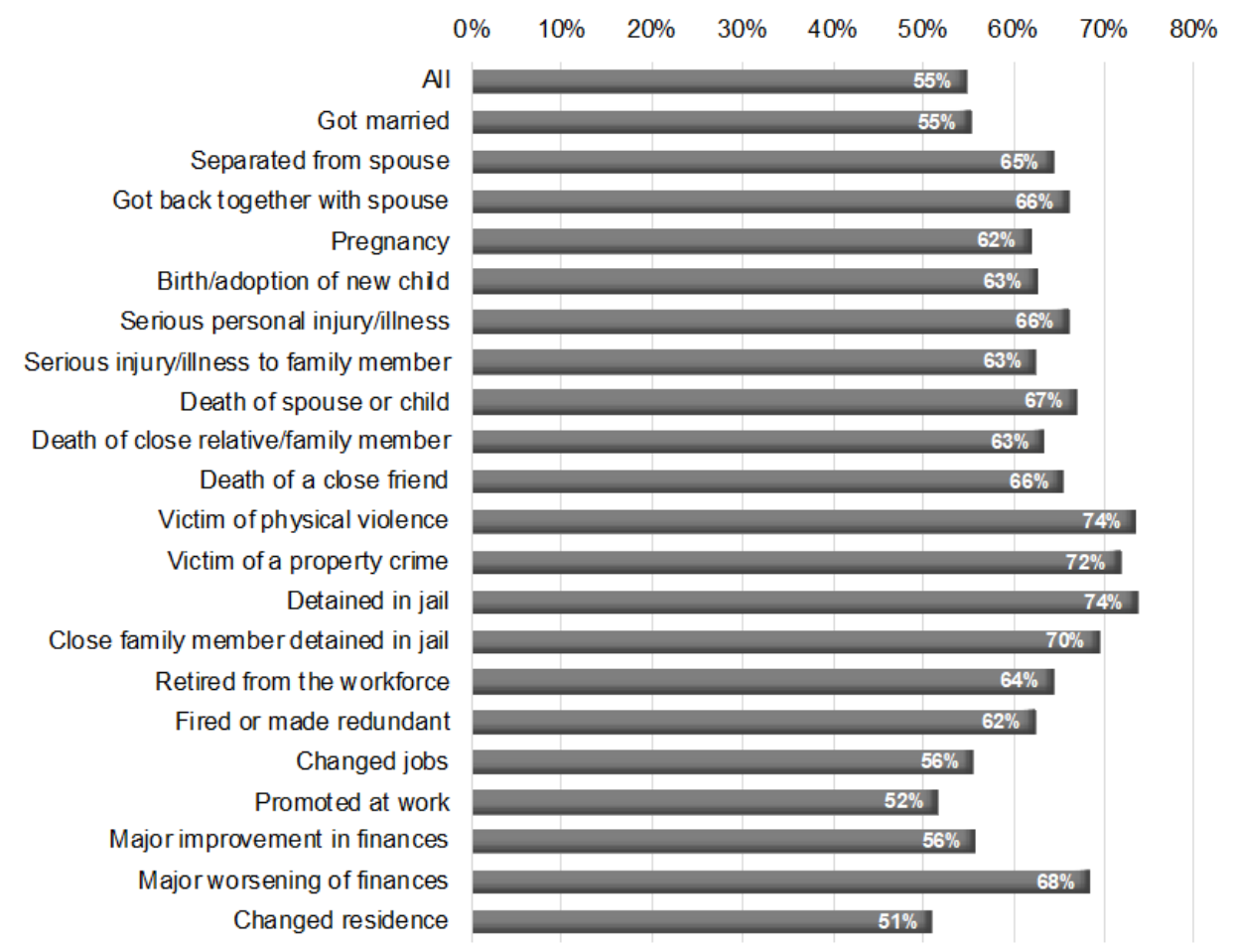

Source: HILDA survey 2002-2018.

\subsection{Some policy considerations}

The key findings reported in this section give rise to a series of important policy considerations.

First, certain population subgroups are clearly more susceptible to poor wellbeing outcomes when precariously housed than others. These tend to be financially constrained groups in the rental sector. Young people are also more vulnerable to falling into and remaining in housing precariousness than older age groups. Clearly, there exists significant scope to better target housing policy measures towards the most vulnerable in the Australian population. The majority of people vulnerable to precarity reside in the rental sector-hence the importance of reform in this sector to provide better housing security, quality and affordability for tenants.

Second, it is clear that precarious housing is associated with poorer wellbeing outcomes-and this is particularly evident in the case of forced moves and unaffordable housing. However, neighbourhood conditions are not unimportant for wellbeing, in particular neighbourhood hostility. The findings emphasise the long-running policy challenge of easing both tenure insecurity and housing affordability pressures in Australia.

Third, the experience of physical violence is a key driver that precipitates a fall into precarious housing, or extends a spell of precarious housing. Other important drivers appear to be property crime, and jail detention of oneself or a close family member. The findings suggest the need for a better integration of housing policy measures with non-housing measures, so as to offer an integrated approach to assisting those suffering from housing precariousness due to non-housing-related factors.

Finally, our models show that the receipt of housing assistance does not have a significant impact on the wellbeing of precariously housed renters. These findings suggest there exists potential for housing-assistance programs - both CRA and public housing - to be improved to increase their effectiveness in improving the wellbeing of precariously housed housing-assistance recipients. 


\section{Policy reflections}

This project has generated an extensive evidence-base that offers an up-to-date national picture on the links between precarious housing, housing assistance and wellbeing. It has addressed four key research questions:

1. How has the relationship between housing precariousness and wellbeing changed over time? Does the bi-directional relationship between housing precariousness and wellbeing vary by household type, income, housing tenure and/or geographical location?

2. Which dimensions of housing precariousness affect wellbeing? Which dimensions of wellbeing affect housing precariousness?

3. Does housing assistance mitigate the influence of housing precariousness on wellbeing?

4. How can policy interventions be timed to effectively minimise any negative impacts of precarious housing on wellbeing?

In the rest of this section, we reflect on our key findings and draw out important policy development options that arise from our findings.

\subsection{Key findings for policy consideration}

\section{Low-income singles and renters are most susceptible to poor wellbeing when precariously housed}

Among the precariously housed, financial constraints and living in the rental sector predispose people to poorer wellbeing outcomes. People living alone, low-income households and public renters are most likely to report low wellbeing at any time point. When housing becomes precarious for a household, those with no children, with lowincomes, renting from a private landlord, and residents of major cities are most likely to suffer a drop in wellbeing. Clearly, there exists significant scope to better target housing policy measures towards the most vulnerable in the Australian population, and these groups (low income, private renters, people living alone and people with wider financial constraints) should be prioritised.

\section{Forced moves and unaffordable housing stand out as being particularly strong drivers of a decline in wellbeing}

While it is clear from this analysis that precarious housing and wellbeing are related-both causally and bi-directionally -this analysis reveals that forced moves and unaffordable housing are in fact significant drivers of this relationship. Across all findings of this analysis, the rental sector-and especially the private rental sector, where tenancy lengths are shorter and rental contracts less secure-are shown to be most affected. This clearly points to the need to improve security in the rental sector, especially in the post-COVID-19 era. 


\section{On their own, CRA and public housing cannot effectively improve the wellbeing of renters who are precariously housed}

There is little evidence that housing assistance, in its current form, has a significant impact on the wellbeing of precariously housed renters. This finding is robust across alternative definitions of housing precariousness and is consistent across housing-assistance types. This finding is not surprising. Existing studies show that, as CRA rules are currently structured, payments to low-income private renters are simply not adequate to achieve benchmark affordability (Henry, Harmer et al. 2010; Wood, Ong et al. 2011). The Productivity Commission (2017) has also acknowledged that the value of CRA has fallen well behind rent inflation, proposing that the CRA ceiling would need to be increased by 15 per cent to restore the 2007 position and that an even bigger increase would be required to achieve this for low-income tenants. Moreover, the Henry Review (2010) highlights that there remains scope for improved targeting so that CRA eligibility rules are more closely aligned with the needs of different cohorts and accommodate the differences in housing markets within Australia. Furthermore, since few conditions are imposed upon private rental landlords in Australia, CRA is not designed to address issues with service quality and tenure insecurity (Hulse, Milligan et al. 2011).

These findings suggest there exists potential for reforming housing-assistance programs-both CRA and public housing-so that they can more effectively improve the wellbeing of precariously housed recipients. Moreover, while such forms of assistance may not be able to provide absolute security of tenure, sub-programs within them could target households predisposed to financial hardship, such as sole-income households, to assist with the related drivers of precarity - such as housing affordability.

\section{People are most likely to fall into or remain in precarious housing when they are young, suffer physical violence or experience jail detention}

Young people are more vulnerable to falling into and remaining in housing precariousness than older age groups. Among the 25-34-years age band, 19 per cent fall into precarious housing and 24 per cent stay in precarious housing from year to year. On the other hand, only 4 per cent of the $65+$ years age group fall into precarious housing and just 12 per cent stay in precarious housing from year to year.

Some major life events are also particularly powerful precipitators of transitions into precarious housing or prolonging spells in precarious housing. Twenty-two per cent of those who suffered physical violence while not precariously housed in the past year fall into precarious housing in the following year. Three-quarters of victims of physical violence who were in precarious housing in the past year find themselves unable to escape into stable housing by the following year. Similar proportions of those who have been detained in jail in the past year also enter into or remain in precarious housing.

\subsection{Policy options}

\section{Better targeting of housing assistance is needed towards low-income singles with no children}

Financially constrained singles are most exposed to poor wellbeing outcomes when precariously housed. Various studies have suggested that households with children receive more generous welfare assistance than single households without children. Ong, Pawson et al. (2020) find that single private renters are most likely to be in housing stress and yet not receive CRA, while households with children are most likely to receive CRA while not being in housing stress. Similarly, Burke, Stone et al. (2011) find that single private renters face the greatest affordability problem, but the scale of the problem diminishes as the number of children increases. This suggests a need to consider both housing assistance and other forms of welfare, to ensure that they offer assistance in an equitable manner across different household types. 


\section{The tenure-security needs of low-income private renters and public renters need to be addressed as a matter of policy priority}

The findings from this report point to poor wellbeing scores among precariously housed public renters. They also suggest that when private renters fall into precarious housing, their wellbeing scores fall by a greater extent than other housing tenures. Related to this, forced moves are a key depressant of wellbeing. The scope for improving tenure security in the rental sector is therefore significant. The private rental sector in Australia is currently lightly regulated regarding lease terms and rent levels. A renter's tenure security could be improved if they had the ability to exercise choice over tenancy length (Martin, Hulse et al. 2018). Tighter rent regulation or rent price control-as in countries such as Spain, Belgium and Germany - can also offer greater protection by preventing landlords from trying to 'price out' tenants in an attempt to force them out of a tenancy (Iwata and Yamaga 2008; Minnery, Adkins et al. 2003). Abolishing 'without grounds' tenancy termination will also have the effect of improving tenure security (Martin, Hulse et al. 2018). The public-housing sector offers greater tenure security. However, a key challenge remains in the long public-housing waiting lists because of a shortage of supply relative to demand. There is therefore scope for diverting government expenditure towards reducing long waiting lists by expanding the supply of social housing in Australia.

\section{There is scope for reforming the current CRA structure to improve the wellbeing of precariously housed renters}

The current CRA structure cannot effectively improve the wellbeing of precariously housed private renters. Various studies have suggested that the current CRA structure is ineffective in achieving a meaningful reduction in housing stress among low-income private renters (Henry, Harmer et al. 2010; Wood, Ong et al. 2011). The real value of CRA has fallen well behind rent inflation (Productivity Commission 2017) and there remains scope for improved targeting so that CRA entitlements more closely match the needs of different population cohorts (Henry, Harmer et al. 2010). Ong, Pawson et al. (2020) find that while over two-thirds of low-income private renters are assisted by CRA, onethird of low-income CRA recipients remain in moderate to very severe housing stress after CRA is deducted from their rents. They model various reforms to CRA and propose that changing CRA eligibility rules to better align with housing need would offer the greatest benefits by reducing the numbers of low-income rental tenants in housing stress by 44 per cent while generating fiscal savings of $\$ 1.2$ billion per year.

\section{Better integration of housing and non-housing policy measures is needed during stages in the life course when exposure to precarious housing is greatest}

Vulnerability to precarious housing is greatest:

- in earlier stages of the life course

- when a victim to physical violence

- when facing jail detention.

On their own, neither CRA nor public-housing assistance are effective for improving the wellbeing of the precariously housed. Therefore, there is a need for better integration of housing policy measures with non-housing measures, so as to offer an integrated approach to assisting those suffering from housing precariousness due to non-housingrelated factors. This may include whole-of-sector support for youths who are at risk of homelessness or facing prolonged unemployment, including assistance with job search and labour-market training, coupled with access to shelter.

Stronger protections against domestic violence that package both housing and non-housing-support measures are needed. Flanagan, Blunden et al. (2019) note that the needs of victims leaving violence are diverse, and while the crisis system offers important support for many, more investment into a range of affordable housing options that are safe, secure and supportive is needed. The study also highlights the need for better integration between domestic and family violence response and the wider housing system so those leaving violent relationships can access long-term, safe and appropriate housing. In addition, Baldry, McDonnell et al. (2003) propose that each prisoner should be offered the assistance of trained caseworkers for housing, personal and advocacy support both before and after release from prison. 


\subsection{Final remarks}

This report contributes to a large and complex literature exploring the relationships between housing and wellbeing. It is motivated by a growing global recognition that the costs and benefits of systems that provide goods and services - and of the interventions that shape them-should increasingly be measured against the yardstick of wellbeing. The provision of shelter is a key example. So if the test of a well-functioning housing system is the wellbeing of its residents, the findings of this report present a major challenge for the Australian housing system. Housing unaffordability has persisted and, along with forced moves, it continues to disrupt the wellbeing of Australians. Low-income singles, young people, physical violence victims and individuals leaving the institutional (criminal) system are overly exposed to precarious housing, which can further perpetuate nonhousing vulnerabilities such as the risk of poverty and re-victimisation.

The report findings are, of course, subject to some modelling limitations. For instance, some wellbeing studies have proposed that although a person's wellbeing level may be impacted by certain events, there is a tendency for the person's wellbeing to return to its baseline level over time (Diener, Suh et al. 1999). This adaptation effect is not captured in our analysis. Another limitation that requires further modelling interventions is the presence of endogeneity in the relationship between precarious housing and wellbeing - that is, we find that precarious housing affects wellbeing but wellbeing also affects precarious housing. We have modelled the two relationships separately in our report, but a more sophisticated approach would be to model the two simultaneously through a modelling framework that addresses this simultaneity issue.

Notwithstanding the modelling limitations, the report's findings suggest that precarious housing is signalling a failure of the housing system to protect the most vulnerable in our society. Housing is increasingly a key marker, not just of wealth inequality, but also of wellbeing inequality between the rich and the poor. Yet, the main planks of housing-assistance policy for renters in Australia do not appear to be effective mechanisms for improving the wellbeing of the precariously housed. Clearly, there remains significant scope-and urgency - to consider and implement housing policy reforms that address these failures, so as to narrow the wellbeing inequality that persists between those who suffer from precarious housing and those who enjoy secure housing in Australia. 


\section{References}

Aitken, Z., Baker, E., Badland, H., Mason, K., Bentley, R., Beer, A. and Kavanagh, A.M. (2019) 'Precariously placed: housing affordability, quality and satisfaction of Australians with disabilities', Disability \& Society, vol. 34, no. 1: 121-142.

Australian Bureau of Statistics (2016a) Housing suitability (HOSD), ABS, Canberra. https://www.abs.gov.au/ausstats/ abs@.nsf/Lookup/by\%20Subject/2900.0 2016 Main\%20Features HOSD\%20Household\%20Suitability 10123

Australian Bureau of Statistics (2016b) Equivalised total household income (weekly) (HIED), ABS, Canberra. https://www. abs.gov.au/ausstats/abs@.nsf/Lookup/by\%20Subject/2900.0 2016 Main\%20Features HIED\%20Equivalised\%20 Total\%20Household\%20Income\%20(weekly) 10120

Australian Bureau of Statistics (2018) Index of relative socio-economic advantage and disadvantage (IRSAD), ABS, Canberra. https://www.abs.gov.au/ausstats/abs@.nsf/Lookup/by\%20Subject/2033.0.55.001 2016 Main\%20 Features IRSAD 20

Australian Bureau of Statistics (2021) Residential property price indexes: eight capital cities, ABS, Canberra. https://www abs.gov.au/statistics/economy/price-indexes-and-inflation/residential-property-price-indexes-eight-capital-cities/ latest-release

Baker, E., Bentley, R. and Mason, K. (2013) 'The mental health effects of housing tenure: causal or compositional?', Urban Studies, vol. 50, no. 2: 426-442.

Baker, E., Bentley, R., Beer, A. and Daniel, L. (2020) Renting in the time of COVID-19: understanding the impacts, Final Report No. 340, Australian Housing and Urban Research Institute Limited, Melbourne, https://www.ahuri.edu.au/ research/final-reports/340, doi:10.18408/ahuri3125401.

Baker, E., Lester, L., Beer, A. and Bentley, R. (2019) 'An Australian geography of unhealthy housing', Geographical Research, vol. 57, no. 1: 40-51.

Baker, E., Lester, L.H., Bentley, R. and Beer, A. (2016) 'Poor housing quality: Prevalence and health effects', Journal of Prevention \& Intervention in the Community, vol. 44, no. 4: 219-232.

Baker, E., Mason, K., Bentley, R., and Mallett, S. (2014) 'Exploring the bi-directional relationship between health and housing in Australia', Urban Policy and Research, vol. 32, no. 1: 71-84.

Baker, E., Pham, A., Leishman, C., Daniel, L. and Bentley, R. (2021) 'Urban social housing pathways: a linked administrative data analysis', Urban Policy and Research, vol. 39, no. 1: 1-15.

Baldry, E., McDonnell, D., Maplestone, P. and Peeters, M. (2003) Ex-prisoners and accommodation: what bearing do different forms of housing have on social integration?, Final Report No. 46, Australian Housing and Urban Research Institute, Melbourne, https://www.ahuri.edu.au/research/final-reports/46/.

Beer, A., Bentley, R., Baker, E., Mason, K., Mallett, S., Kavanagh, A., and LaMontagne, T. (2016) 'Neoliberalism, economic restructuring and policy change: precarious housing and precarious employment in Australia', Urban Studies, vol. 53, no. 8: 1542-1558.

Bentley, R., Baker, E., Mason, K., Subramanian, S.V. and Kavanagh, A.M. (2011) 'Association between housing affordability and mental health: a longitudinal analysis of a nationally representative household survey in Australia', American Journal of Epidemiology, vol. 174, no. 7: 753-760.

Bentley, R., Pevalin, D., Baker, E., Mason, K., Reeves, A., and Beer, A. (2016) 'Housing affordability, tenure and mental health in Australia and the United Kingdom: a comparative panel analysis', Housing Studies, vol. 31, no. 2: $208-222$. 
Brooks, C. (2014) Introductory Econometrics for Finance, 3rd ed., Cambridge University Press, New York.

Buckle, C., Gurran, N., Phibbs, P., Harris, P., Lea, T. and Shrivastava, R. (2020) Marginal housing during COVID-19, Final Report No. 348, Australian Housing and Urban Research Institute, Melbourne, https://www.ahuri.edu.au/research/ final-reports/348, doi:10.18408/ahuri7325501.

Burke, T., Stone, M. and Ralston, L. (2011) The residual income method: a new lens on housing affordability and market behaviour, Final Report No.176, Australian Housing and Urban Research Institute, Melbourne, https://www.ahuri. edu.au/research/final-reports/176.

Clair, A., Reeves, A., McKee, M. and Stuckler, D. (2019) 'Constructing a housing precariousness measure for Europe', Journal of European Social Policy, vol. 29, no. 1:13-28.

Diener, E., Suh, E.M., Lucas, R.E., Smith, H.E. (1999) 'Subjective well-being: three decades of progress', Psychological Bulletin, vol. 125, no. 2: 276-302.

European Parliamentary Research Service (2014) Measuring well-being and progress: looking beyond GDP, EPRS, accessed 23 July 2019, http://www.europarl.europa.eu/EPRS/140738REV1-Measuring-well-being-and-progressFINAL.pdf.

Flanagan, K., Blunden, H., Valentine, K. and Henriette, J. (2019) Housing outcomes after domestic and family violence, Final Report No. 311, Australian Housing and Urban Research Institute Limited, Melbourne, http://www.ahuri.edu. au/research/final-reports/311, doi: 10.18408/ahuri-4116101.

Gurran, N., Hulse, K., Dodson, J., Pill, M., Dowling, R., Reynolds, M. and Maalsen, S. (2021) Urban productivity and affordable rental housing supply in Australian cities and regions, Final Report No. 353, Australian Housing and Urban Research Institute Limited, Melbourne, https://www.ahuri.edu.au/research/final-reports/353, doi:10.18408/ ahuri5323001.

Henry, K., Harmer, J., Piggott, J., Ridout, H. and Smith, G. (2010) Australia's future tax system: report to the treasurer, accessed 15 August 2019, http://www.taxreview.treasury.gov.au.

Hulse, K. and Saugeres, L. (2008) Housing insecurity and precarious living: an Australian exploration, Final Report No. 124, Australian Housing and Urban Research Institute, Melbourne, https://www.ahuri.edu.au/research/finalreports/124.

Hulse, K. and Yates, J. (2017) 'A private rental sector paradox: unpacking the effects of urban restructuring on housing market dynamics', Housing Studies, vol. 32, no. 3: 253-270.

Hulse, K., Milligan, V. and Easthope, H. (2011) Secure occupancy in rental housing: conceptual foundations and comparative perspectives, Final Report No. 170, Australian Housing and Urban Research Institute, Melbourne, https://www.ahuri.edu.au/research/final-reports/170.

Iwata, S. and Yamaga, H. (2008) 'Rental externality, tenure security, and housing quality', Journal of Housing Economics, vol. 17, no. 3: 201-211.

Kavanagh, A.M., Aitken, Z., Baker, E., LaMontagne, A.D., Milner, A. and Bentley, R. (2016) 'Housing tenure and affordability and mental health following disability acquisition in adulthood', Social Science \& Medicine, vol. 151, no. 1: 225-232.

Mallett, S., Bentley, R., Baker, E., Mason, K., Keys, D., Kolar, V. and Krnjacki, L. (2011) Precarious housing and health inequalities: what are the links?, Hanover Welfare Services, University of Melbourne, University of Adelaide, Melbourne Citymission, Australia. https://www.vichealth.vic.gov.au/media-and-resources/publications/precarioushousing-and-health-inequalities.

Martin, C., Hulse, K. and Pawson, H. (2018) The changing institutions of private rental housing: an international review, Final Report No. 292, Australian Housing and Urban Research Institute, Melbourne, https://www.ahuri.edu.au/ research/final-reports/292, doi: 10.18408/ahuri-7112201.

McKee, K. (2012), 'Young people, homeownership and future welfare', Housing Studies, vol. 27, no. 6: 853-862.

Minnery, J., Adkins, B., Grimbeek, P., Summerville, J., Mead, E. and Guthrie, D. (2003) Tenure security and its impact on private renters in Queensland, Final Report No. 27, Australian Housing and Urban Research Institute, Melbourne, https://www.ahuri.edu.au/research/final-reports/27.

Mundlak, Y. (1978) ‘On the pooling of time series and cross section data', Econometrica, vol. 46, no. 1: 69-85. 
Nygaard, C., Pinnegar, S., Taylor, L., Levin, I. and Maguire, R. (2021) Evaluation and learning in public housing urban renewal, Final Report No. 358, Australian Housing and Urban Research Institute Limited, Melbourne, https://www. ahuri.edu.au/research/final-reports/358, doi:10.18408/ahuri51226.

Ong, R., Nguyen, T. and Kendall, G. (2018) 'The impact of intergenerational financial transfers on health and wellbeing outcomes: a longitudinal study', Social Science and Medicine, vol. 214: 179-186.

Ong, R., Pawson, H., Singh, R. and Martin, C. (2020) Demand-side assistance in Australia's rental housing market: exploring reform option, Final Report No. 342, Australian Housing and Urban Research Institute, Melbourne, https://www.ahuri.edu.au/research/finalreports/342, doi: 10.18408/ahuri8120801.

Ong, R., Wood, G., Cigdem-Bayram, M. and Salazar, S. (2019) Mortgage stress and precarious home ownership: implications for older Australians, Final Report No. 319, Australian Housing and Urban Research Institute, Melbourne, https://www.ahuri.edu.au/research/final-reports/319, doi:10.18408/ahuri-8118901.

Organisation for Economic Cooperation and Development (2019) OECD better life initiative: measuring well-being and progress, OECD, accessed 23 July 2019, https://www.oecd.org/sdd/OECD-Better-Life-Initiative.pdf.

Parkinson, S., Ong, R., Cigdem, M. and Taylor, E. (2014) Wellbeing outcomes of lower income renters: a multilevel analysis of area effects, Final Report No. 226, Australian Housing and Urban Research Institute, Melbourne, https://www. ahuri.edu.au/research/final-reports/226.

Productivity Commission (2017) Introducing competition and informed user choice into human services: reforms to human services, Report No. 85, Productivity Commission, Canberra, https://www.pc.gov.au/inquiries/completed/ human-services/reforms/report.

Rowley, S. and Ong, R. (2012) Housing affordability, housing stress and household wellbeing in Australia, Final Report No. 192, Australian Housing and Urban Research Institute, Melbourne, https://www.ahuri.edu.au/research/finalreports/192.

Rowley, S., Ong, R. and Haffner, M. (2015) 'Bridging the gap between housing stress and financial stress: the case of Australia', Housing Studies, vol. 30, no. 3: 473-490.

Ryu, E., Juhn, Y., Wheeler, P., Hathcock, M., Wi, C., Olson, J., Cerhan, J. and Takahashi, P. (2017) 'Individual housing-based socioeconomic status predicts risk of accidental falls among adults', Annals of Epidemiology, vol. 27, no. 7: 415-420, doi: https://doi.org/10.1016/j.annepidem.2017.05.019.

Stone, W., Rowley, S., Parkinson, S., James, A. and Spinney, A. (2020) The housing aspirations of Australians across the life-course: closing the 'housing aspirations gap', Final Report No. 337, Australian Housing and Urban Research Institute, Melbourne, https://www.ahuri.edu.au/research/final-reports/337, doi:10.18408/ahuri-5117001.

Treasury NZ (2019) The wellbeing budget, accessed 23 July 2019, https://budget.govt.nz/budget/2019/wellbeing/ approach/index.htm.

Ware, J.E. (2000) 'SF-36 health survey update', Spine, vol. 25, no. 24: 3130-3139, doi: 10.1097/00007632-20001215000008.

Wood, G.A., Smith, S.J., Cigdem, M. and Ong, R. (2017) 'Life on the edge: a perspective on precarious home ownership in Australia and the UK', International Journal of Housing Policy, vol. 17, no. 2: 201-226.

Wood, G., Ong, R. and Cigdem, M. (2014) Housing affordability dynamics: new insights from the last decade, Final Report No. 233, Australian Housing and Urban Research Institute, Melbourne, https://www.ahuri.edu.au/research/finalreports/233.

Wood, G., Ong, R. and McMurray, C. (2011) The impacts of the Henry Review recommendations on the private rental market: savings income discount and rent assistance, Final Report No. 175, Australian Housing and Urban Research Institute, Melbourne, https://www.ahuri.edu.au/research/final-reports/175.

Wood, G., Smith, S.J., Ong, R. and Cigdem, M. (2013) The edges of home ownership, Final Report No. 216, Australian Housing and Urban Research Institute, Melbourne, https://www.ahuri.edu.au/research/final-reports/216.

Zabel, J. (2015) 'The hedonic model and the housing cycle', Regional Science and Urban Economics, vol. 54: 74-86, doi: https://doi.org/10.1016/j.regsciurbeco.2015.07.005. 


\section{Appendix: Detailed regression tables}

Table A1: Regression control variables

\begin{tabular}{|c|c|c|}
\hline Variable category & Binary or continuous & Variable definition \\
\hline \multirow[t]{5}{*}{ Housing tenure } & \multirow[t]{5}{*}{ Binary } & Outright owner (reference) \\
\hline & & Owner with mortgage \\
\hline & & Private renter \\
\hline & & Public renter \\
\hline & & Other tenure type \\
\hline Children & Binary & Have at least one dependent child \\
\hline \multirow[t]{6}{*}{ Marital status } & \multirow[t]{6}{*}{ Binary } & Legally married (reference) \\
\hline & & De facto \\
\hline & & Separated \\
\hline & & Divorced \\
\hline & & Widowed \\
\hline & & Single not married \\
\hline \multirow[t]{6}{*}{ Age band } & \multirow[t]{6}{*}{ Binary } & 15-24 (reference) \\
\hline & & $25-34$ \\
\hline & & $35-44$ \\
\hline & & $45-54$ \\
\hline & & $55-64$ \\
\hline & & $65+$ \\
\hline Health & Binary & Has long-term health condition \\
\hline \multirow[t]{6}{*}{ Highest qualification } & \multirow[t]{6}{*}{ Binary } & Postgraduate \\
\hline & & Graduate diploma \\
\hline & & Undergraduate \\
\hline & & Diploma \\
\hline & & Certificate \\
\hline & & Year 12 or below (reference) \\
\hline \multirow[t]{4}{*}{ Labour force status } & \multirow[t]{4}{*}{ Binary } & Full-time \\
\hline & & Part-time \\
\hline & & Unemployed \\
\hline & & Not in the labour force \\
\hline
\end{tabular}




\begin{tabular}{|c|c|c|}
\hline Variable category & Binary or continuous & Variable definition \\
\hline \multirow[t]{13}{*}{ Geographical region } & \multirow[t]{13}{*}{ Binary } & Sydney (reference) \\
\hline & & Balance of NSW \\
\hline & & Melbourne \\
\hline & & Balance of VIC \\
\hline & & Brisbane \\
\hline & & Balance of QLD \\
\hline & & Adelaide \\
\hline & & Balance of SA \\
\hline & & Perth \\
\hline & & Balance of WA \\
\hline & & Tasmania \\
\hline & & Northern Territory \\
\hline & & Australian Capital Territory \\
\hline Income & Continuous & $\begin{array}{l}\text { Equivalised household disposable income }\left(\${ }^{\prime} 00,000\right) \text { is generated } \\
\text { by dividing the unequivalised income of each person's household } \\
\text { by a factor that is drawn from the OECD modified equivalence scale. } \\
\text { According to the OECD modified equivalence scale, the first adult } \\
\text { is allocated } 1 \text { point, with a further } 0.5 \text { points allocated for every } \\
\text { additional individual aged } 15 \text { years or older, and } 0.3 \text { for each child } \\
\text { under } 15 \text { years old (ABS } 2016 \text { b). The equivalised income is then } \\
\text { inflated into real terms at } 2018 \text { price levels using the Consumer } \\
\text { Price Index. }\end{array}$ \\
\hline \multirow[t]{18}{*}{ Year / wave } & \multirow[t]{18}{*}{ Binary } & Wave 1 or 2001 (reference) \\
\hline & & Wave 2 or 2002 \\
\hline & & Wave 3 or 2003 \\
\hline & & Wave 4 or 2004 \\
\hline & & Wave 5 or 2005 \\
\hline & & Wave 6 or 2006 \\
\hline & & Wave 7 or 2007 \\
\hline & & Wave 8 or 2008 \\
\hline & & Wave 9 or 2009 \\
\hline & & Wave 10 or 2010 \\
\hline & & Wave 11 or 2011 \\
\hline & & Wave 12 or 2012 \\
\hline & & Wave 13 or 2013 \\
\hline & & Wave 14 or 2014 \\
\hline & & Wave 15 or 2015 \\
\hline & & Wave 16 or 2016 \\
\hline & & Wave 17 or 2017 \\
\hline & & Wave 18 or 2018 \\
\hline
\end{tabular}


Table A2: Effect of housing precariousness at $t$ on wellbeing at $t+1$, full regression results from fixed effects OLS models, 2002-2018

\begin{tabular}{|c|c|c|c|c|c|c|c|}
\hline Predictors & $\begin{array}{r}\text { Wellbeing } \\
\text { index }\end{array}$ & $\begin{array}{r}\text { Satisfaction } \\
\text { with life }\end{array}$ & $\begin{array}{r}\text { Satisfaction with } \\
\text { employment } \\
\text { opportunities }\end{array}$ & $\begin{array}{r}\text { Satisfaction } \\
\text { with finances }\end{array}$ & $\begin{array}{r}\text { Satisfaction } \\
\text { with community }\end{array}$ & $\begin{array}{l}\text { Mental } \\
\text { health }\end{array}$ & $\begin{array}{r}\text { Physical } \\
\text { functioning }\end{array}$ \\
\hline Forced move $t+1$ & $\begin{array}{r}-0.074^{\star \star \star} \\
(0.008)\end{array}$ & $\begin{array}{r}-0.079 * * \star \\
(0.017)\end{array}$ & $\begin{array}{r}-0.095^{\star \star \star} \\
(0.029)\end{array}$ & $\begin{array}{r}-0.216^{\star \star \star} \\
(0.024)\end{array}$ & $\begin{array}{r}-0.120 * * * \\
(0.025)\end{array}$ & $\begin{array}{r}-1.244^{\star \star \star} \\
(0.190)\end{array}$ & $\begin{array}{l}-0.204 \\
(0.235)\end{array}$ \\
\hline Unaffordability & $\begin{array}{r}-0.039^{\star \star \star} \\
(0.007)\end{array}$ & $\begin{array}{r}-0.039^{\star \star \star} \\
(0.012)\end{array}$ & $\begin{array}{r}-0.064^{\star \star \star} \\
(0.023)\end{array}$ & $\begin{array}{r}-0.129^{\star \star \star} \\
(0.018)\end{array}$ & $\begin{array}{l}-0.015 \\
(0.018)\end{array}$ & $\begin{array}{r}-0.395^{\star \star \star} \\
(0.142)\end{array}$ & $\begin{array}{r}-0.331^{*} \\
(0.175)\end{array}$ \\
\hline Overcrowded & $\begin{array}{r}-0.021^{\star *} \\
(0.010)\end{array}$ & $\begin{array}{l}-0.016 \\
(0.019)\end{array}$ & $\begin{array}{l}-0.047 \\
(0.034)\end{array}$ & $\begin{array}{r}-0.055^{\star *} \\
(0.027)\end{array}$ & $\begin{array}{r}0.013 \\
(0.028)\end{array}$ & $\begin{array}{l}-0.108 \\
(0.220)\end{array}$ & $\begin{array}{l}-0.161 \\
(0.272)\end{array}$ \\
\hline $\begin{array}{l}\text { Neighbourhood } \\
\text { crime }\end{array}$ & $\begin{array}{r}-0.006^{\star *} \\
(0.002)\end{array}$ & $\begin{array}{r}-0.009^{* *} \\
(0.004)\end{array}$ & $\begin{array}{r}0.013 \\
(0.008)\end{array}$ & $\begin{array}{r}-0.019^{* * *} \\
(0.006)\end{array}$ & $\begin{array}{r}-0.025^{\star \star *} \\
(0.006)\end{array}$ & $\begin{array}{l}-0.031 \\
(0.048)\end{array}$ & $\begin{array}{r}0.088 \\
(0.059)\end{array}$ \\
\hline $\begin{array}{l}\text { Neighbourhood } \\
\text { hostility }\end{array}$ & $\begin{array}{r}-0.014^{\star \star \star} \\
(0.002)\end{array}$ & $\begin{array}{r}-0.020^{\star * *} \\
(0.004)\end{array}$ & $\begin{array}{r}-0.021^{* * *} \\
(0.008)\end{array}$ & $\begin{array}{r}-0.019^{\star \star \star} \\
(0.006)\end{array}$ & $\begin{array}{r}-0.044^{\star \star *} \\
(0.006)\end{array}$ & $\begin{array}{r}-0.138^{\star \star \star} \\
(0.048)\end{array}$ & $\begin{array}{l}-0.053 \\
(0.059)\end{array}$ \\
\hline $\begin{array}{l}\text { SEIFA index reverse } \\
\text { scored, divided by } 100\end{array}$ & $\begin{array}{r}-0.008^{\star \star} \\
(0.003)\end{array}$ & $\begin{array}{r}-0.018^{\star \star *} \\
(0.006)\end{array}$ & $\begin{array}{l}-0.020 \\
(0.011)\end{array}$ & $\begin{array}{r}0.027^{\star \star \star} \\
(0.009)\end{array}$ & $\begin{array}{r}-0.043^{\star \star \star} \\
(0.009)\end{array}$ & $\begin{array}{r}0.022 \\
(0.071)\end{array}$ & $\begin{array}{r}-0.417^{* \star *} \\
(0.088)\end{array}$ \\
\hline Owner with mortgage & $\begin{array}{l}-0.005 \\
(0.005)\end{array}$ & $\begin{array}{r}-0.033^{\star \star \star} \\
(0.010)\end{array}$ & $\begin{array}{r}0.010 \\
(0.019)\end{array}$ & $\begin{array}{r}-0.062^{\star \star \star} \\
(0.015)\end{array}$ & $\begin{array}{l}-0.009 \\
(0.015)\end{array}$ & $\begin{array}{r}0.034 \\
(0.116)\end{array}$ & $\begin{array}{l}-0.097 \\
(0.143)\end{array}$ \\
\hline Private renter & $\begin{array}{r}-0.021^{\star \star \star} \\
(0.007)\end{array}$ & $\begin{array}{r}-0.035^{\star \star \star} \\
(0.013)\end{array}$ & $\begin{array}{r}0.051^{\star \star} \\
(0.024)\end{array}$ & $\begin{array}{r}-0.116^{\star \star \star} \\
(0.019)\end{array}$ & $\begin{array}{r}-0.121^{\star \star \star} \\
(0.019)\end{array}$ & $\begin{array}{r}0.066 \\
(0.150)\end{array}$ & $\begin{array}{r}-0.617^{\star * \star} \\
(0.185)\end{array}$ \\
\hline Public renter & $\begin{array}{l}-0.025 \\
(0.017)\end{array}$ & $\begin{array}{r}-0.050^{*} \\
(0.029)\end{array}$ & $\begin{array}{r}0.020 \\
(0.056)\end{array}$ & $\begin{array}{r}-0.087^{\star *} \\
(0.043)\end{array}$ & $\begin{array}{r}-0.135^{\star \star \star} \\
(0.044)\end{array}$ & $\begin{array}{l}-0.530 \\
(0.345)\end{array}$ & $\begin{array}{l}-0.268 \\
(0.427)\end{array}$ \\
\hline Other tenure type & $\begin{array}{r}-0.027^{\star \star} \\
(0.012)\end{array}$ & $\begin{array}{r}-0.084^{\star \star \star} \\
(0.021)\end{array}$ & $\begin{array}{r}0.023 \\
(0.041)\end{array}$ & $\begin{array}{r}-0.053^{*} \\
(0.031)\end{array}$ & $\begin{array}{r}-0.124^{\star \star \star} \\
(0.031)\end{array}$ & $\begin{array}{r}0.009 \\
(0.244)\end{array}$ & $\begin{array}{r}-0.939^{* * *} \\
(0.302)\end{array}$ \\
\hline Children & $\begin{array}{r}-0.040^{* * *} \\
(0.005)\end{array}$ & $\begin{array}{r}-0.112^{\star * \star} \\
(0.010)\end{array}$ & $\begin{array}{r}-0.074^{\star \star \star} \\
(0.018)\end{array}$ & $\begin{array}{r}-0.198^{\star * \star} \\
(0.015)\end{array}$ & $\begin{array}{r}0.063^{\star \star \star} \\
(0.015)\end{array}$ & $\begin{array}{r}-0.861^{\star \star \star} \\
(0.118)\end{array}$ & $\begin{array}{r}0.553^{\star * \star} \\
(0.146)\end{array}$ \\
\hline De facto & $\begin{array}{r}0.026^{\star \star \star} \\
(0.007)\end{array}$ & $\begin{array}{r}0.086^{\star \star \star} \\
(0.015)\end{array}$ & $\begin{array}{r}0.058^{\star \star} \\
(0.026)\end{array}$ & $\begin{array}{r}0.048^{\star \star} \\
(0.021)\end{array}$ & $\begin{array}{r}-0.064^{\star \star \star} \\
(0.022)\end{array}$ & $\begin{array}{r}0.613^{\star \star \star} \\
(0.168)\end{array}$ & $\begin{array}{r}-0.856^{\star \star \star} \\
(0.208)\end{array}$ \\
\hline Separated & $\begin{array}{r}-0.062^{\star \star \star} \\
(0.012)\end{array}$ & $\begin{array}{r}-0.179^{\star \star \star} \\
(0.022)\end{array}$ & $\begin{array}{r}0.017 \\
(0.039)\end{array}$ & $\begin{array}{r}-0.418^{\star \star \star} \\
(0.031)\end{array}$ & $\begin{array}{r}-0.099 * \star \star \\
(0.032)\end{array}$ & $\begin{array}{r}0.257 \\
(0.250)\end{array}$ & $\begin{array}{l}-0.027 \\
(0.308)\end{array}$ \\
\hline Divorced & $\begin{array}{l}-0.009 \\
(0.012)\end{array}$ & $\begin{array}{r}0.024 \\
(0.022)\end{array}$ & $\begin{array}{r}-0.107^{\star \star} \\
(0.041)\end{array}$ & $\begin{array}{r}-0.234^{\star \star \star} \\
(0.032)\end{array}$ & $\begin{array}{l}-0.042 \\
(0.033)\end{array}$ & $\begin{array}{r}1.932^{\star \star \star} \\
(0.251)\end{array}$ & $\begin{array}{l}-0.101 \\
(0.311)\end{array}$ \\
\hline Widowed & $\begin{array}{r}-0.045^{\star \star} \\
(0.022)\end{array}$ & $\begin{array}{r}-0.058^{\star *} \\
(0.026)\end{array}$ & $\begin{array}{l}-0.003 \\
(0.079)\end{array}$ & $\begin{array}{l}-0.059 \\
(0.037)\end{array}$ & $\begin{array}{r}-0.144^{\star \star *} \\
(0.039)\end{array}$ & $\begin{array}{r}1.192^{\star \star *} \\
(0.293)\end{array}$ & $\begin{array}{r}-3.385^{\star \star \star} \\
(0.364)\end{array}$ \\
\hline Single, not married & $\begin{array}{l}-0.004 \\
(0.010)\end{array}$ & $\begin{array}{l}-0.024 \\
(0.019)\end{array}$ & $\begin{array}{r}0.068^{\star \star} \\
(0.033)\end{array}$ & $\begin{array}{r}-0.087^{\star * \star} \\
(0.028)\end{array}$ & $\begin{array}{r}-0.076^{\star \star \star} \\
(0.029)\end{array}$ & $\begin{array}{r}0.193 \\
(0.225)\end{array}$ & $\begin{array}{r}-1.192^{\star \star \star} \\
(0.278)\end{array}$ \\
\hline Age 25-34 & $\begin{array}{r}0.019^{\star \star} \\
(0.008)\end{array}$ & $\begin{array}{r}0.002 \\
(0.016)\end{array}$ & $\begin{array}{r}0.048 \\
(0.028)\end{array}$ & $\begin{array}{l}-0.006 \\
(0.023)\end{array}$ & $\begin{array}{r}0.103^{\star \star \star} \\
(0.024)\end{array}$ & $\begin{array}{l}-0.180 \\
(0.190)\end{array}$ & $\begin{array}{r}3.291^{\star \star \star} \\
(0.234)\end{array}$ \\
\hline Age 35-44 & $\begin{array}{l}0.021^{\star} \\
(0.012)\end{array}$ & $\begin{array}{l}-0.006 \\
(0.023)\end{array}$ & $\begin{array}{r}0.024 \\
(0.042)\end{array}$ & $\begin{array}{r}-0.083^{\star *} \\
(0.033)\end{array}$ & $\begin{array}{r}0.235^{\star \star \star} \\
(0.034)\end{array}$ & $\begin{array}{r}0.084 \\
(0.265)\end{array}$ & $\begin{array}{r}6.765^{\star \star \star} \\
(0.327)\end{array}$ \\
\hline Age 45-54 & $\begin{array}{r}0.004 \\
(0.016)\end{array}$ & $\begin{array}{r}0.026 \\
(0.029)\end{array}$ & $\begin{array}{l}-0.048 \\
(0.054)\end{array}$ & $\begin{array}{r}-0.150^{\star \star \star} \\
(0.042)\end{array}$ & $\begin{array}{r}0.227^{\star \star \star} \\
(0.043)\end{array}$ & $\begin{array}{c}0.772^{\star \star} \\
(0.329)\end{array}$ & $\begin{array}{r}8.858^{\star \star \star} \\
(0.406)\end{array}$ \\
\hline Age 55-64 & $\begin{array}{r}0.007 \\
(0.019)\end{array}$ & $\begin{array}{r}0.155^{\star \star \star} \\
(0.035)\end{array}$ & $\begin{array}{r}-0.123^{\star} \\
(0.068)\end{array}$ & $\begin{array}{r}-0.111^{\star \star} \\
(0.051)\end{array}$ & $\begin{array}{r}0.270^{\star \star \star} \\
(0.052)\end{array}$ & $\begin{array}{r}2.083^{\star \star \star *} \\
(0.398)\end{array}$ & $\begin{array}{r}10.395^{\star \star *} \\
(0.492)\end{array}$ \\
\hline Age 65+ & $\begin{array}{r}0.093^{\star \star \star} \\
(0.025)\end{array}$ & $\begin{array}{r}0.273^{\star \star \star} \\
(0.042)\end{array}$ & $\begin{array}{r}0.512^{\star \star \star} \\
(0.087)\end{array}$ & $\begin{array}{r}0.032 \\
(0.061)\end{array}$ & $\begin{array}{r}0.352^{\star \star \star} \\
(0.063)\end{array}$ & $\begin{array}{r}3.327^{\star \star \star} \\
(0.477)\end{array}$ & $\begin{array}{r}11.100^{\star \star \star} \\
(0.589)\end{array}$ \\
\hline
\end{tabular}




\begin{tabular}{|c|c|c|c|c|c|c|c|}
\hline Predictors & $\begin{array}{r}\text { Wellbeing } \\
\text { index }\end{array}$ & $\begin{array}{r}\text { Satisfaction } \\
\text { with life }\end{array}$ & $\begin{array}{r}\text { Satisfaction with } \\
\text { employment } \\
\text { opportunities }\end{array}$ & $\begin{array}{r}\text { Satisfaction } \\
\text { with finances }\end{array}$ & $\begin{array}{r}\text { Satisfaction } \\
\text { with community }\end{array}$ & $\begin{array}{l}\text { Mental } \\
\text { health }\end{array}$ & $\begin{array}{r}\text { Physical } \\
\text { functioning }\end{array}$ \\
\hline $\begin{array}{l}\text { Has long-term } \\
\text { condition }\end{array}$ & $\begin{array}{r}-0.076^{\star * *} \\
(0.005)\end{array}$ & $\begin{array}{r}-0.085^{\star \star \star} \\
(0.008)\end{array}$ & $\begin{array}{r}-0.151^{\star \star \star} \\
(0.017)\end{array}$ & $\begin{array}{r}-0.056^{\star \star \star} \\
(0.012)\end{array}$ & $\begin{array}{r}-0.039^{\star * *} \\
(0.012)\end{array}$ & $\begin{array}{r}-1.179^{\star * \star} \\
(0.092)\end{array}$ & $\begin{array}{r}-3.515^{\star \star \star} \\
(0.113)\end{array}$ \\
\hline Postgraduate & $\begin{array}{r}0.099^{* * *} \\
(0.023)\end{array}$ & $\begin{array}{r}0.085 \\
(0.046)\end{array}$ & $\begin{array}{r}0.010 \\
(0.078)\end{array}$ & $\begin{array}{r}0.399^{* * *} \\
(0.066)\end{array}$ & $\begin{array}{r}0.329^{* * *} \\
(0.068)\end{array}$ & $\begin{array}{r}1.068^{\star \star} \\
(0.523)\end{array}$ & $\begin{array}{r}3.004^{\star * *} \\
(0.645)\end{array}$ \\
\hline Graduate diploma & $\begin{array}{r}0.072^{\star \star \star} \\
(0.021)\end{array}$ & $\begin{array}{r}0.120^{\star \star \star} \\
(0.042)\end{array}$ & $\begin{array}{r}0.037 \\
(0.072)\end{array}$ & $\begin{array}{r}0.268^{\star \star \star} \\
(0.061)\end{array}$ & $\begin{array}{r}0.330^{* \star *} \\
(0.063)\end{array}$ & $\begin{array}{r}0.645 \\
(0.479)\end{array}$ & $\begin{array}{r}1.671^{\star \star *} \\
(0.591)\end{array}$ \\
\hline Undergraduate & $\begin{array}{r}0.056^{\star \star \star} \\
(0.016)\end{array}$ & $\begin{array}{r}0.032 \\
(0.032)\end{array}$ & $\begin{array}{r}0.020 \\
(0.055)\end{array}$ & $\begin{array}{r}0.309^{\star \star \star} \\
(0.047)\end{array}$ & $\begin{array}{r}0.224^{\star \star \star} \\
(0.048)\end{array}$ & $\begin{array}{r}0.342 \\
(0.370)\end{array}$ & $\begin{array}{r}1.407^{\star \star \star} \\
(0.456)\end{array}$ \\
\hline Diploma & $\begin{array}{r}0.048^{\star \star \star} \\
(0.017)\end{array}$ & $\begin{array}{r}0.012 \\
(0.034)\end{array}$ & $\begin{array}{r}0.149 \star \star \star \\
(0.057)\end{array}$ & $\begin{array}{r}0.156^{\star \star \star} \\
(0.049)\end{array}$ & $\begin{array}{r}0.162^{\star \star \star} \\
(0.050)\end{array}$ & $\begin{array}{r}0.269 \\
(0.385)\end{array}$ & $\begin{array}{l}0.861^{*} \\
(0.475)\end{array}$ \\
\hline Certificate & $\begin{array}{l}-0.005 \\
(0.010)\end{array}$ & $\begin{array}{l}-0.024 \\
(0.020)\end{array}$ & $\begin{array}{r}0.073^{\star \star} \\
(0.035)\end{array}$ & $\begin{array}{r}0.090^{\star \star \star} \\
(0.030)\end{array}$ & $\begin{array}{r}0.005 \\
(0.030)\end{array}$ & $\begin{array}{l}-0.298 \\
(0.235)\end{array}$ & $\begin{array}{r}0.037 \\
(0.290)\end{array}$ \\
\hline Part-time & $\begin{array}{r}-0.014^{\star \star \star} \\
(0.005)\end{array}$ & $\begin{array}{r}0.043^{\star \star \star} \\
(0.010)\end{array}$ & $\begin{array}{r}-0.098^{\star \star \star} \\
(0.017)\end{array}$ & $\begin{array}{r}-0.152^{\star \star \star} \\
(0.014)\end{array}$ & $\begin{array}{r}0.062^{\star \star \star} \\
(0.014)\end{array}$ & $\begin{array}{r}0.225^{\star \star} \\
(0.109)\end{array}$ & $\begin{array}{l}-0.017 \\
(0.135)\end{array}$ \\
\hline Unemployed & $\begin{array}{r}-0.090 * * * \\
(0.009)\end{array}$ & $\begin{array}{r}-0.053^{\star \star \star} \\
(0.018)\end{array}$ & $\begin{array}{r}-0.543^{\star \star \star} \\
(0.032)\end{array}$ & $\begin{array}{r}-0.358^{\star \star \star} \\
(0.026)\end{array}$ & $\begin{array}{l}-0.032 \\
(0.027)\end{array}$ & $\begin{array}{r}0.212 \\
(0.211)\end{array}$ & $\begin{array}{l}-0.118 \\
(0.261)\end{array}$ \\
\hline Not in labour force & $\begin{array}{r}-0.098^{* \star *} \\
(0.006)\end{array}$ & $\begin{array}{r}0.030^{\star *} \\
(0.011)\end{array}$ & $\begin{array}{r}-0.583^{* * \star} \\
(0.022)\end{array}$ & $\begin{array}{r}-0.269^{\star \star \star} \\
(0.016)\end{array}$ & $\begin{array}{r}0.082^{\star * \star} \\
(0.017)\end{array}$ & $\begin{array}{l}-0.175 \\
(0.130)\end{array}$ & $\begin{array}{r}-1.436^{\star \star \star} \\
(0.160)\end{array}$ \\
\hline Balance of NSW & $\begin{array}{l}-0.013 \\
(0.017)\end{array}$ & $\begin{array}{r}0.041 \\
(0.031)\end{array}$ & $\begin{array}{r}-0.383^{* * \star} \\
(0.058)\end{array}$ & $\begin{array}{l}-0.038 \\
(0.044)\end{array}$ & $\begin{array}{r}0.277^{\star * \star} \\
(0.045)\end{array}$ & $\begin{array}{r}0.269 \\
(0.350)\end{array}$ & $\begin{array}{l}-0.578 \\
(0.433)\end{array}$ \\
\hline Melbourne & $\begin{array}{l}-0.001 \\
(0.021)\end{array}$ & $\begin{array}{r}0.017 \\
(0.040)\end{array}$ & $\begin{array}{r}-0.127^{\star} \\
(0.073)\end{array}$ & $\begin{array}{r}0.066 \\
(0.058)\end{array}$ & $\begin{array}{l}-0.023 \\
(0.060)\end{array}$ & $\begin{array}{l}0.767^{\star} \\
(0.465)\end{array}$ & $\begin{array}{l}-0.922 \\
(0.575)\end{array}$ \\
\hline Balance of VIC & $\begin{array}{r}0.006 \\
(0.024)\end{array}$ & $\begin{array}{r}0.007 \\
(0.044)\end{array}$ & $\begin{array}{r}-0.352^{\star \star \star} \\
(0.082)\end{array}$ & $\begin{array}{r}0.035 \\
(0.064)\end{array}$ & $\begin{array}{r}0.304^{\star \star \star} \\
(0.066)\end{array}$ & $\begin{array}{r}0.372 \\
(0.512)\end{array}$ & $\begin{array}{l}-0.694 \\
(0.633)\end{array}$ \\
\hline Brisbane & $\begin{array}{r}0.023 \\
(0.021)\end{array}$ & $\begin{array}{r}0.052 \\
(0.038)\end{array}$ & $\begin{array}{l}-0.076 \\
(0.070)\end{array}$ & $\begin{array}{r}0.035 \\
(0.055)\end{array}$ & $\begin{array}{r}0.178^{* \star *} \\
(0.057)\end{array}$ & $\begin{array}{r}0.522 \\
(0.440)\end{array}$ & $\begin{array}{r}-1.031^{\star} \\
(0.543)\end{array}$ \\
\hline Balance of QLD & $\begin{array}{l}0.034^{\star} \\
(0.020)\end{array}$ & $\begin{array}{r}0.089^{\star \star} \\
(0.036)\end{array}$ & $\begin{array}{r}-0.271^{\star \star \star} \\
(0.067)\end{array}$ & $\begin{array}{r}0.069 \\
(0.051)\end{array}$ & $\begin{array}{r}0.363^{\star \star \star} \\
(0.053)\end{array}$ & $\begin{array}{r}0.626 \\
(0.408)\end{array}$ & $\begin{array}{r}0.098 \\
(0.504)\end{array}$ \\
\hline Adelaide & $\begin{array}{l}-0.043 \\
(0.030)\end{array}$ & $\begin{array}{r}0.008 \\
(0.056)\end{array}$ & $\begin{array}{r}-0.245^{\star \star} \\
(0.103)\end{array}$ & $\begin{array}{l}-0.024 \\
(0.081)\end{array}$ & $\begin{array}{r}-0.208^{* * *} \\
(0.084)\end{array}$ & $\begin{array}{l}-0.130 \\
(0.644)\end{array}$ & $\begin{array}{l}-0.126 \\
(0.795)\end{array}$ \\
\hline Balance of SA & $\begin{array}{r}0.019 \\
(0.036)\end{array}$ & $\begin{array}{r}0.031 \\
(0.066)\end{array}$ & $\begin{array}{r}-0.360 * \star * \\
(0.122)\end{array}$ & $\begin{array}{r}0.127 \\
(0.095)\end{array}$ & $\begin{array}{r}0.483^{\star * *} \\
(0.097)\end{array}$ & $\begin{array}{l}-0.021 \\
(0.755)\end{array}$ & $\begin{array}{l}-0.424 \\
(0.934)\end{array}$ \\
\hline Perth & $\begin{array}{r}0.020 \\
(0.027)\end{array}$ & $\begin{array}{r}0.112^{\star *} \\
(0.052)\end{array}$ & $\begin{array}{r}-0.336^{\star \star \star} \\
(0.093)\end{array}$ & $\begin{array}{r}0.149 * \star \\
(0.075)\end{array}$ & $\begin{array}{r}0.074 \\
(0.077)\end{array}$ & $\begin{array}{r}2.748^{\star \star \star} \\
(0.595)\end{array}$ & $\begin{array}{r}0.732 \\
(0.733)\end{array}$ \\
\hline Balance of WA & $\begin{array}{r}0.126^{\star \star \star} \\
(0.034)\end{array}$ & $\begin{array}{r}0.112 \\
(0.062)\end{array}$ & $\begin{array}{l}-0.105 \\
(0.114)\end{array}$ & $\begin{array}{r}0.378^{\star * *} \\
(0.089)\end{array}$ & $\begin{array}{r}0.376^{\star \star \star} \\
(0.091)\end{array}$ & $\begin{array}{r}2.952^{\star \star \star} \\
(0.713)\end{array}$ & $\begin{array}{r}0.196 \\
(0.878)\end{array}$ \\
\hline Tasmania & $\begin{array}{l}-0.032 \\
(0.033)\end{array}$ & $\begin{array}{r}0.072 \\
(0.063)\end{array}$ & $\begin{array}{r}-0.531^{* * *} \\
(0.116)\end{array}$ & $\begin{array}{r}0.045 \\
(0.091)\end{array}$ & $\begin{array}{r}0.273^{\star * \star} \\
(0.094)\end{array}$ & $\begin{array}{r}0.534 \\
(0.720)\end{array}$ & $\begin{array}{l}-0.128 \\
(0.887)\end{array}$ \\
\hline Northern Territory & $\begin{array}{r}0.032 \\
(0.032)\end{array}$ & $\begin{array}{r}-0.025 \\
(0.063)\end{array}$ & $\begin{array}{l}-0.136 \\
(0.109)\end{array}$ & $\begin{array}{r}0.250^{\star * \star} \\
(0.090)\end{array}$ & $\begin{array}{r}0.303^{\star * *} \\
(0.093)\end{array}$ & $\begin{array}{l}-0.129 \\
(0.725)\end{array}$ & $\begin{array}{l}-0.236 \\
(0.895)\end{array}$ \\
\hline $\begin{array}{l}\text { Australian Capital } \\
\text { Territory }\end{array}$ & $\begin{array}{r}0.025 \\
(0.029)\end{array}$ & $\begin{array}{r}0.035 \\
(0.054)\end{array}$ & $\begin{array}{l}-0.063 \\
(0.100)\end{array}$ & $\begin{array}{r}0.068 \\
(0.078)\end{array}$ & $\begin{array}{r}0.173^{\star \star} \\
(0.081)\end{array}$ & $\begin{array}{r}0.348 \\
(0.619)\end{array}$ & $\begin{array}{l}-0.602 \\
(0.766)\end{array}$ \\
\hline $\begin{array}{l}\text { Real, equivalised } \\
\text { disposable income } \\
\left(\$^{\prime} 00,000\right)\end{array}$ & $\begin{array}{r}0.018^{\star * *} \\
(0.004)\end{array}$ & $\begin{array}{r}0.026^{\star \star *} \\
(0.006)\end{array}$ & $\begin{array}{r}0.004 \\
(0.014)\end{array}$ & $\begin{array}{r}0.101^{\star \star \star} \\
(0.009)\end{array}$ & $\begin{array}{l}-0.012 \\
(0.009)\end{array}$ & $\begin{array}{r}0.097 \\
(0.067)\end{array}$ & $\begin{array}{r}0.005 \\
(0.083)\end{array}$ \\
\hline
\end{tabular}




\begin{tabular}{|c|c|c|c|c|c|c|c|}
\hline Predictors & $\begin{array}{r}\text { Wellbeing } \\
\text { index }\end{array}$ & $\begin{array}{r}\text { Satisfaction } \\
\text { with life }\end{array}$ & $\begin{array}{r}\text { Satisfaction with } \\
\text { employment } \\
\text { opportunities }\end{array}$ & $\begin{array}{r}\text { Satisfaction } \\
\text { with finances }\end{array}$ & $\begin{array}{r}\text { Satisfaction } \\
\text { with community }\end{array}$ & $\begin{array}{l}\text { Mental } \\
\text { health }\end{array}$ & $\begin{array}{r}\text { Physical } \\
\text { functioning }\end{array}$ \\
\hline Wave 2 & $\begin{array}{r}0.069^{\star \star \star} \\
(0.008)\end{array}$ & $\begin{array}{r}0.066^{\star \star \star} \\
(0.015)\end{array}$ & $\begin{array}{r}0.189^{\star \star \star} \\
(0.029)\end{array}$ & $\begin{array}{r}0.344^{\star * *} \\
(0.021)\end{array}$ & $\begin{array}{r}0.085^{\star \star \star} \\
(0.022)\end{array}$ & $\begin{array}{l}-0.143 \\
(0.167)\end{array}$ & $\begin{array}{r}-0.913^{\star * \star} \\
(0.208)\end{array}$ \\
\hline Wave 3 & $\begin{array}{r}0.082^{\star \star \star} \\
(0.008)\end{array}$ & $\begin{array}{r}0.041^{\star \star \star} \\
(0.015)\end{array}$ & $\begin{array}{r}0.225^{\star \star \star} \\
(0.029)\end{array}$ & $\begin{array}{r}0.371^{\star \star \star} \\
(0.022)\end{array}$ & $\begin{array}{r}0.124^{\star \star \star} \\
(0.022)\end{array}$ & $\begin{array}{r}-0.297^{\star} \\
(0.169)\end{array}$ & $\begin{array}{r}-1.210^{\star \star \star} \\
(0.210)\end{array}$ \\
\hline Wave 4 & $\begin{array}{r}0.072^{\star \star \star} \\
(0.009)\end{array}$ & $\begin{array}{l}-0.020 \\
(0.015)\end{array}$ & $\begin{array}{r}0.246^{\star \star \star} \\
(0.030)\end{array}$ & $\begin{array}{r}0.422^{\star \star \star} \\
(0.022)\end{array}$ & $\begin{array}{r}0.083^{* \star *} \\
(0.022)\end{array}$ & $\begin{array}{l}-0.235 \\
(0.172)\end{array}$ & $\begin{array}{r}-2.319^{* \star *} \\
(0.213)\end{array}$ \\
\hline Wave 5 & $\begin{array}{r}0.078^{\star \star \star} \\
(0.009)\end{array}$ & $\begin{array}{r}-0.053^{\star * \star} \\
(0.015)\end{array}$ & $\begin{array}{r}0.310^{\star \star \star} \\
(0.030)\end{array}$ & $\begin{array}{r}0.429^{\star \star \star} \\
(0.022)\end{array}$ & $\begin{array}{r}0.084^{\star \star \star} \\
(0.023)\end{array}$ & $\begin{array}{r}-0.306^{\star} \\
(0.174)\end{array}$ & $\begin{array}{r}-2.590^{\star * *} \\
(0.217)\end{array}$ \\
\hline Wave 6 & $\begin{array}{r}0.105^{\star \star \star} \\
(0.009)\end{array}$ & $\begin{array}{r}-0.059^{\star \star \star} \\
(0.016)\end{array}$ & $\begin{array}{r}0.461^{\star \star \star} \\
(0.031)\end{array}$ & $\begin{array}{r}0.553^{\star \star \star} \\
(0.023)\end{array}$ & $\begin{array}{r}0.077^{\star \star \star} \\
(0.023)\end{array}$ & $\begin{array}{r}-0.311^{\star} \\
(0.177)\end{array}$ & $\begin{array}{r}-3.467^{\star \star \star} \\
(0.220)\end{array}$ \\
\hline Wave 7 & $\begin{array}{r}0.094^{\star \star \star} \\
(0.009)\end{array}$ & $\begin{array}{r}-0.074^{\star \star \star} \\
(0.016)\end{array}$ & $\begin{array}{r}0.406^{\star \star \star} \\
(0.032)\end{array}$ & $\begin{array}{r}0.502^{\star \star \star} \\
(0.024)\end{array}$ & $\begin{array}{r}0.049^{\star \star} \\
(0.024)\end{array}$ & $\begin{array}{r}-0.555^{\star \star \star} \\
(0.185)\end{array}$ & $\begin{array}{r}-3.803^{\star \star \star} \\
(0.229)\end{array}$ \\
\hline Wave 8 & $\begin{array}{r}0.090^{\star * \star} \\
(0.009)\end{array}$ & $\begin{array}{r}-0.062^{\star * *} \\
(0.016)\end{array}$ & $\begin{array}{r}0.264^{\star \star \star} \\
(0.032)\end{array}$ & $\begin{array}{r}0.520^{\star * \star} \\
(0.023)\end{array}$ & $\begin{array}{r}0.056^{\star *} \\
(0.024)\end{array}$ & $\begin{array}{l}-0.025 \\
(0.184)\end{array}$ & $\begin{array}{r}-4.615^{\star \star \star} \\
(0.228)\end{array}$ \\
\hline Wave 9 & $\begin{array}{r}0.059^{\star \star \star} \\
(0.010)\end{array}$ & $\begin{array}{r}-0.101^{\star * *} \\
(0.017)\end{array}$ & $\begin{array}{r}0.253^{\star \star \star} \\
(0.034)\end{array}$ & $\begin{array}{r}0.467^{\star \star \star} \\
(0.024)\end{array}$ & $\begin{array}{r}0.088^{\star \star \star *} \\
(0.025)\end{array}$ & $\begin{array}{r}-0.752^{\star \star \star} \\
(0.191)\end{array}$ & $\begin{array}{r}-5.965^{\star \star \star} \\
(0.237)\end{array}$ \\
\hline Wave 10 & $\begin{array}{r}0.083^{* * *} \\
(0.010)\end{array}$ & $\begin{array}{r}-0.079 * * \star \\
(0.017)\end{array}$ & $\begin{array}{r}0.235^{\star \star \star} \\
(0.033)\end{array}$ & $\begin{array}{r}0.553^{\star \star \star} \\
(0.024)\end{array}$ & $\begin{array}{r}0.139^{\star * *} \\
(0.025)\end{array}$ & $\begin{array}{r}-0.546^{\star \star \star} \\
(0.189)\end{array}$ & $\begin{array}{r}-6.291^{\star \star \star} \\
(0.235)\end{array}$ \\
\hline Wave 11 & $\begin{array}{r}0.071^{\star \star \star} \\
(0.010)\end{array}$ & $\begin{array}{r}-0.099 \star \star \star \\
(0.018)\end{array}$ & $\begin{array}{r}0.186^{\star \star \star} \\
(0.035)\end{array}$ & $\begin{array}{r}0.585^{\star \star \star} \\
(0.025)\end{array}$ & $\begin{array}{r}0.035 \\
(0.026)\end{array}$ & $\begin{array}{r}-0.387^{\star} \\
(0.197)\end{array}$ & $\begin{array}{r}-7.098^{\star \star \star} \\
(0.244)\end{array}$ \\
\hline Wave 12 & $\begin{array}{r}0.051^{\star * \star} \\
(0.010)\end{array}$ & $\begin{array}{r}-0.091^{\star \star \star} \\
(0.017)\end{array}$ & $\begin{array}{r}0.101^{\star \star \star} \\
(0.034)\end{array}$ & $\begin{array}{r}0.650^{\star \star \star} \\
(0.025)\end{array}$ & $\begin{array}{l}-0.011 \\
(0.025)\end{array}$ & $\begin{array}{r}-0.431^{\star *} \\
(0.193)\end{array}$ & $\begin{array}{r}-7.828^{\star \star \star} \\
(0.239)\end{array}$ \\
\hline Wave 13 & $\begin{array}{r}0.057^{\star \star \star} \\
(0.010)\end{array}$ & $\begin{array}{r}-0.084^{\star \star \star} \\
(0.018)\end{array}$ & $\begin{array}{r}0.077^{\star *} \\
(0.036)\end{array}$ & $\begin{array}{r}0.662^{\star * \star} \\
(0.026)\end{array}$ & $\begin{array}{r}0.141^{\star \star \star} \\
(0.026)\end{array}$ & $\begin{array}{r}-1.057^{\star \star \star} \\
(0.200)\end{array}$ & $\begin{array}{r}-8.705^{\star \star \star} \\
(0.248)\end{array}$ \\
\hline Wave 14 & $\begin{array}{r}0.065^{\star * \star} \\
(0.010)\end{array}$ & $\begin{array}{r}-0.099^{\star \star \star *} \\
(0.018)\end{array}$ & $\begin{array}{r}0.081^{\star \star} \\
(0.037)\end{array}$ & $\begin{array}{r}0.724^{\star \star \star} \\
(0.026)\end{array}$ & $\begin{array}{r}0.166^{\star * \star} \\
(0.027)\end{array}$ & $\begin{array}{r}-1.290^{\star \star \star} \\
(0.203)\end{array}$ & $\begin{array}{r}-9.185^{\star \star \star} \\
(0.251)\end{array}$ \\
\hline Wave 15 & $\begin{array}{r}0.075^{\star \star \star} \\
(0.011)\end{array}$ & $\begin{array}{r}-0.090^{\star \star \star} \\
(0.019)\end{array}$ & $\begin{array}{r}0.117^{\star \star \star} \\
(0.038)\end{array}$ & $\begin{array}{r}0.759^{\star \star \star} \\
(0.027)\end{array}$ & $\begin{array}{r}0.163^{\star \star \star} \\
(0.028)\end{array}$ & $\begin{array}{r}-1.249^{\star \star \star} \\
(0.210)\end{array}$ & $\begin{array}{r}-9.492^{\star \star \star} \\
(0.260)\end{array}$ \\
\hline Wave 16 & $\begin{array}{r}0.054^{* * *} \\
(0.011)\end{array}$ & $\begin{array}{r}-0.118^{\star * *} \\
(0.019)\end{array}$ & $\begin{array}{r}0.141^{\star * *} \\
(0.039)\end{array}$ & $\begin{array}{r}0.849^{* * *} \\
(0.027)\end{array}$ & $\begin{array}{r}0.031 \\
(0.028)\end{array}$ & $\begin{array}{r}-1.421^{\star * *} \\
(0.213)\end{array}$ & $\begin{array}{r}-10.716^{\star \star \star} \\
(0.264)\end{array}$ \\
\hline Wave 17 & $\begin{array}{r}0.087^{\star * \star} \\
(0.012)\end{array}$ & $\begin{array}{r}-0.065^{\star \star *} \\
(0.020)\end{array}$ & $\begin{array}{r}0.281^{\star \star \star} \\
(0.041)\end{array}$ & $\begin{array}{r}0.873^{\star * \star} \\
(0.028)\end{array}$ & $\begin{array}{r}0.210^{\star * *} \\
(0.029)\end{array}$ & $\begin{array}{r}-1.807^{\star \star \star} \\
(0.221)\end{array}$ & $\begin{array}{r}-11.183^{\star \star \star} \\
(0.275)\end{array}$ \\
\hline Constant & $\begin{array}{r}4.628^{\star \star \star} \\
(0.021)\end{array}$ & $\begin{array}{r}8.009^{\star \star \star} \\
(0.040)\end{array}$ & $\begin{array}{r}7.235^{\star \star \star} \\
(0.071)\end{array}$ & $\begin{array}{r}6.246^{\star \star \star} \\
(0.057)\end{array}$ & $\begin{array}{r}6.573^{\star \star \star *} \\
(0.059)\end{array}$ & $\begin{array}{r}74.055^{\star \star \star} \\
(0.456)\end{array}$ & $\begin{array}{r}83.099 * \star \star \\
(0.563)\end{array}$ \\
\hline$N$ & 127,145 & 179,414 & 138,266 & 179,397 & 179,209 & 167,449 & 166,210 \\
\hline $\mathrm{R}^{2}$ & 0.136 & 0.045 & 0.083 & 0.070 & 0.053 & 0.026 & 0.001 \\
\hline F-stat & $23.74^{\star \star \star}$ & $17.03^{\star \star \star}$ & $34.20^{\star \star \star}$ & $72.52^{\star \star \star}$ & $21.93^{\star \star \star}$ & $12.00^{\star \star \star}$ & $119.40^{\star \star \star}$ \\
\hline
\end{tabular}

Notes: ${ }^{* \star *} p<0.01,{ }^{* *} p<0.05,{ }^{*} p<0.1$. The reference categories are outright owner, no dependent children, legally married, age 15-24, highest qualification from high school, full-time employed, Sydney and Wave 1. Standard errors are reported in parentheses.

Source: HILDA survey 2002-2018. 
Table A3: Effect of wellbeing at $t$ on housing precariousness at $t+1$, full regression results from fixed effects logit and OLS models, 2002-2018

\begin{tabular}{|c|c|c|c|c|c|c|c|c|}
\hline \multirow[b]{2}{*}{ Predictors } & \multicolumn{4}{|c|}{ Logit - Odds Ratios } & \multicolumn{4}{|c|}{ OLS - Coefficients } \\
\hline & Private renter & Forced move & $\begin{array}{r}\text { Unaffordable } \\
\text { housing }\end{array}$ & Overcrowded & $\begin{array}{r}\text { Neighbourhood } \\
\text { crime }\end{array}$ & $\begin{array}{r}\text { Neighbourhood } \\
\text { hostility }\end{array}$ & $\begin{array}{r}\text { SEIFA - reverse } \\
\text { scored }\end{array}$ & $\begin{array}{r}\text { Precarious } \\
\text { index }\end{array}$ \\
\hline Satisfaction with life & $\begin{array}{r}0.967^{\star \star \star *} \\
(0.012)\end{array}$ & $\begin{array}{r}0.951^{* \star *} \\
(0.015)\end{array}$ & $\begin{array}{r}1.018 \\
(0.013)\end{array}$ & $\begin{array}{r}0.943^{\star \star \star} \\
(0.019)\end{array}$ & $\begin{array}{r}-0.007^{\star * \star} \\
(0.002)\end{array}$ & $\begin{array}{r}-0.010^{* \star *} \\
(0.002)\end{array}$ & $\begin{array}{r}-0.002^{*} \\
(0.001)\end{array}$ & $\begin{array}{r}-0.010^{* * *} \\
(0.001)\end{array}$ \\
\hline $\begin{array}{l}\text { Satisfaction with employment } \\
\text { opportunities }\end{array}$ & $\begin{array}{r}1.021^{\star \star \star} \\
(0.008)\end{array}$ & $\begin{array}{r}0.995 \\
(0.010)\end{array}$ & $\begin{array}{r}1.001 \\
(0.008)\end{array}$ & $\begin{array}{r}1.004 \\
(0.012)\end{array}$ & $\begin{array}{r}0.000 \\
(0.001)\end{array}$ & $\begin{array}{r}0.000 \\
(0.001)\end{array}$ & $\begin{array}{l}-0.001 \\
(0.001)\end{array}$ & $\begin{array}{r}0.000 \\
(0.001)\end{array}$ \\
\hline Satisfaction with finance & $\begin{array}{r}0.945^{\star \star \star} \\
(0.008)\end{array}$ & $\begin{array}{r}0.977^{\star *} \\
(0.010)\end{array}$ & $\begin{array}{r}0.932^{\star \star \star} \\
(0.008)\end{array}$ & $\begin{array}{r}0.969^{\star \star} \\
(0.013)\end{array}$ & $\begin{array}{l}-0.001 \\
(0.001)\end{array}$ & $\begin{array}{l}-0.002 \\
(0.001)\end{array}$ & $\begin{array}{r}0.002^{\star \star} \\
(0.001)\end{array}$ & $\begin{array}{r}-0.006^{\star \star \star} \\
(0.001)\end{array}$ \\
\hline Satisfaction with community & $\begin{array}{r}0.978^{\star \star \star} \\
(0.007)\end{array}$ & $\begin{array}{r}0.988 \\
(0.010)\end{array}$ & $\begin{array}{r}0.992 \\
(0.008)\end{array}$ & $\begin{array}{r}0.992 \\
(0.012)\end{array}$ & $\begin{array}{r}-0.017^{\star \star \star} \\
(0.001)\end{array}$ & $\begin{array}{r}-0.018^{\star * \star} \\
(0.001)\end{array}$ & $\begin{array}{r}-0.004^{\star \star \star} \\
(0.001)\end{array}$ & $\begin{array}{r}-0.011^{\star \star \star} \\
(0.001)\end{array}$ \\
\hline Mental health (divided by 10) & $\begin{array}{r}0.988 \\
(0.011)\end{array}$ & $\begin{array}{r}0.965^{\star \star \star} \\
(0.013)\end{array}$ & $\begin{array}{r}0.982 \\
(0.011)\end{array}$ & $\begin{array}{r}1.003 \\
(0.018)\end{array}$ & $\begin{array}{r}-0.009^{\star * \star} \\
(0.002)\end{array}$ & $\begin{array}{r}-0.017^{\star \star \star} \\
(0.002)\end{array}$ & $\begin{array}{r}0.001 \\
(0.001)\end{array}$ & $\begin{array}{r}-0.009^{* * *} \\
(0.001)\end{array}$ \\
\hline Physical functioning (divided by 10) & $\begin{array}{r}0.999 \\
(0.009)\end{array}$ & $\begin{array}{r}1.014 \\
(0.012)\end{array}$ & $\begin{array}{r}0.980^{\star \star} \\
(0.009)\end{array}$ & $\begin{array}{r}1.004 \\
(0.014)\end{array}$ & $\begin{array}{r}-0.003^{\star * \star} \\
(0.001)\end{array}$ & $\begin{array}{r}-0.004^{\star *} \\
(0.001)\end{array}$ & $\begin{array}{r}-0.003^{\star * \star} \\
(0.001)\end{array}$ & $\begin{array}{r}-0.003^{* *} \\
(0.001)\end{array}$ \\
\hline Owner with mortgage & $\begin{array}{r}0.549^{\star \star \star} \\
(0.028)\end{array}$ & $\begin{array}{l}0.809^{* *} \\
(0.084)\end{array}$ & $\begin{array}{r}2.080^{\star \star \star} \\
(0.142)\end{array}$ & $\begin{array}{r}0.578^{\star \star \star} \\
(0.050)\end{array}$ & $\begin{array}{l}-0.007 \\
(0.007)\end{array}$ & $\begin{array}{r}-0.021^{\star \star \star} \\
(0.007)\end{array}$ & $\begin{array}{r}0.001 \\
(0.005)\end{array}$ & $\begin{array}{r}-0.008^{*} \\
(0.005)\end{array}$ \\
\hline Private renter & $\begin{array}{r}6.333^{\star \star \star} \\
(0.286)\end{array}$ & $\begin{array}{r}3.044^{\star \star \star} \\
(0.292)\end{array}$ & $\begin{array}{r}2.167^{\star \star \star} \\
(0.154)\end{array}$ & $\begin{array}{r}0.613^{\star \star \star} \\
(0.059)\end{array}$ & $\begin{array}{r}0.033^{\star \star \star} \\
(0.009)\end{array}$ & $\begin{array}{r}0.010 \\
(0.009)\end{array}$ & $\begin{array}{r}-0.030^{\star \star \star} \\
(0.006)\end{array}$ & $\begin{array}{r}0.078^{\star \star \star *} \\
(0.006)\end{array}$ \\
\hline Public renter & $\begin{array}{r}1.564^{\star \star \star} \\
(0.134)\end{array}$ & $\begin{array}{r}0.932 \\
(0.154)\end{array}$ & $\begin{array}{r}0.718^{\star *} \\
(0.097)\end{array}$ & $\begin{array}{r}0.569^{\star \star \star} \\
(0.088)\end{array}$ & $\begin{array}{r}0.152^{\star \star \star} \\
(0.022)\end{array}$ & $\begin{array}{r}0.181^{* * *} \\
(0.022)\end{array}$ & $\begin{array}{r}0.149^{* \star *} \\
(0.014)\end{array}$ & $\begin{array}{r}0.018 \\
(0.015)\end{array}$ \\
\hline Other tenure type & $\begin{array}{r}2.599^{\star \star \star} \\
(0.187)\end{array}$ & $\begin{array}{r}2.728^{\star \star \star} \\
(0.359)\end{array}$ & $\begin{array}{l}1.259^{\star} \\
(0.151)\end{array}$ & $\begin{array}{l}0.764^{\star} \\
(0.114)\end{array}$ & $\begin{array}{r}0.013 \\
(0.017)\end{array}$ & $\begin{array}{l}-0.003 \\
(0.016)\end{array}$ & $\begin{array}{r}-0.064^{* \star *} \\
(0.011)\end{array}$ & $\begin{array}{l}0.021^{\star} \\
(0.011)\end{array}$ \\
\hline Children & $\begin{array}{r}0.836^{\star \star *} \\
(0.037)\end{array}$ & $\begin{array}{r}0.852^{\star * *} \\
(0.053)\end{array}$ & $\begin{array}{r}1.270^{\star * \star} \\
(0.064)\end{array}$ & $\begin{array}{r}1.944^{\star \star \star} \\
(0.159)\end{array}$ & $\begin{array}{l}-0.007 \\
(0.007)\end{array}$ & $\begin{array}{r}-0.034^{\star * *} \\
(0.007)\end{array}$ & $\begin{array}{r}-0.029^{* \star *} \\
(0.005)\end{array}$ & $\begin{array}{l}-0.001 \\
(0.005)\end{array}$ \\
\hline De facto & $\begin{array}{r}1.563^{\star \star \star} \\
(0.083)\end{array}$ & $\begin{array}{r}1.191^{\star \star} \\
(0.097)\end{array}$ & $\begin{array}{r}0.788^{\star \star \star} \\
(0.054)\end{array}$ & $\begin{array}{r}0.976 \\
(0.111)\end{array}$ & $\begin{array}{r}0.030^{\star * *} \\
(0.010)\end{array}$ & $\begin{array}{r}0.013 \\
(0.010)\end{array}$ & $\begin{array}{r}0.027^{\star \star \star *} \\
(0.006)\end{array}$ & $\begin{array}{r}0.006 \\
(0.007)\end{array}$ \\
\hline Separated & $\begin{array}{r}2.335^{\star \star \star} \\
(0.190)\end{array}$ & $\begin{array}{r}1.354^{\star \star \star} \\
(0.154)\end{array}$ & $\begin{array}{r}1.723^{\star \star \star} \\
(0.152)\end{array}$ & $\begin{array}{r}0.954 \\
(0.140)\end{array}$ & $\begin{array}{r}-0.026^{\star} \\
(0.016)\end{array}$ & $\begin{array}{r}0.009 \\
(0.016)\end{array}$ & $\begin{array}{r}0.084^{\star \star *} \\
(0.010)\end{array}$ & $\begin{array}{r}0.038^{\star \star \star \star} \\
(0.011)\end{array}$ \\
\hline Divorced & $\begin{array}{r}2.083^{\star \star *} \\
(0.181)\end{array}$ & $\begin{array}{r}1.451^{\star \star \star} \\
(0.178)\end{array}$ & $\begin{array}{r}1.375^{\star \star \star} \\
(0.134)\end{array}$ & $\begin{array}{r}1.000 \\
(0.164)\end{array}$ & $\begin{array}{r}0.020 \\
(0.016)\end{array}$ & $\begin{array}{r}0.017 \\
(0.016)\end{array}$ & $\begin{array}{r}0.074^{\star * *} \\
(0.010)\end{array}$ & $\begin{array}{r}0.038^{\star \star \star} \\
(0.011)\end{array}$ \\
\hline
\end{tabular}




\begin{tabular}{|c|c|c|c|c|c|c|c|c|}
\hline \multirow[b]{2}{*}{ Predictors } & \multicolumn{4}{|c|}{ Logit - Odds Ratios } & \multicolumn{4}{|c|}{ OLS - Coefficients } \\
\hline & Private renter & Forced move & $\begin{array}{r}\text { Unaffordable } \\
\text { housing }\end{array}$ & Overcrowded & $\begin{array}{r}\text { Neighbourhood } \\
\text { crime }\end{array}$ & $\begin{array}{r}\text { Neighbourhood } \\
\text { hostility }\end{array}$ & $\begin{array}{r}\text { SEIFA - reverse } \\
\text { scored }\end{array}$ & $\begin{array}{r}\text { Precarious } \\
\text { index }\end{array}$ \\
\hline Widowed & $\begin{array}{r}1.342 \\
(0.285)\end{array}$ & $\begin{array}{r}0.942 \\
(0.314)\end{array}$ & $\begin{array}{l}1.546^{\star} \\
(0.345)\end{array}$ & $\begin{array}{l}1.672^{*} \\
(0.506)\end{array}$ & $\begin{array}{r}-0.107^{* * *} \\
(0.030)\end{array}$ & $\begin{array}{l}0.036 \\
(0.03)\end{array}$ & $\begin{array}{r}0.061^{\star \star *} \\
(0.020)\end{array}$ & $\begin{array}{r}0.004 \\
(0.020)\end{array}$ \\
\hline Single, not married & $\begin{array}{r}1.996^{\star \star *} \\
(0.132)\end{array}$ & $\begin{array}{r}1.135 \\
(0.110)\end{array}$ & $\begin{array}{r}1.347^{\star \star \star} \\
(0.109)\end{array}$ & $\begin{array}{r}1.818^{* \star *} \\
(0.247)\end{array}$ & $\begin{array}{r}0.038^{* * *} \\
(0.013)\end{array}$ & $\begin{array}{r}0.017 \\
(0.013)\end{array}$ & $\begin{array}{r}0.005 \\
(0.008)\end{array}$ & $\begin{array}{r}0.043^{* * *} \\
(0.009)\end{array}$ \\
\hline Age 25-34 & $\begin{array}{r}1.089 \\
(0.060)\end{array}$ & $\begin{array}{r}0.835^{\star *} \\
(0.062)\end{array}$ & $\begin{array}{r}1.002 \\
(0.064)\end{array}$ & $\begin{array}{r}0.581^{* * *} \\
(0.063)\end{array}$ & $\begin{array}{r}0.064^{\star * *} \\
(0.011)\end{array}$ & $\begin{array}{l}-0.003 \\
(0.011)\end{array}$ & $\begin{array}{l}-0.004 \\
(0.007)\end{array}$ & $\begin{array}{r}-0.034^{\star * \star *} \\
(0.007)\end{array}$ \\
\hline Age 35-44 & $\begin{array}{r}0.941 \\
(0.087)\end{array}$ & $\begin{array}{r}0.748^{\star *} \\
(0.096)\end{array}$ & $\begin{array}{r}0.970 \\
(0.100)\end{array}$ & $\begin{array}{r}0.771 \\
(0.130)\end{array}$ & $\begin{array}{r}0.054^{\star * \star} \\
(0.016)\end{array}$ & $\begin{array}{r}0.000 \\
(0.016)\end{array}$ & $\begin{array}{r}-0.057^{\star \star *} \\
(0.010)\end{array}$ & $\begin{array}{r}-0.051^{* \star *} \\
(0.011)\end{array}$ \\
\hline Age 45-54 & $\begin{array}{r}0.878 \\
(0.115)\end{array}$ & $\begin{array}{l}0.737^{\star} \\
(0.135)\end{array}$ & $\begin{array}{r}1.011 \\
(0.144)\end{array}$ & $\begin{array}{r}0.783 \\
(0.176)\end{array}$ & $\begin{array}{r}0.050^{\star \star} \\
(0.021)\end{array}$ & $\begin{array}{r}0.018 \\
(0.021)\end{array}$ & $\begin{array}{r}-0.069^{\star \star *} \\
(0.014)\end{array}$ & $\begin{array}{r}-0.048^{\star \star *} \\
(0.014)\end{array}$ \\
\hline Age 55-64 & $\begin{array}{r}0.798 \\
(0.141)\end{array}$ & $\begin{array}{r}0.802 \\
(0.201)\end{array}$ & $\begin{array}{r}0.952 \\
(0.180)\end{array}$ & $\begin{array}{r}0.656 \\
(0.195)\end{array}$ & $\begin{array}{r}0.003 \\
(0.026)\end{array}$ & $\begin{array}{r}0.006 \\
(0.026)\end{array}$ & $\begin{array}{r}-0.037^{\star \star} \\
(0.017)\end{array}$ & $\begin{array}{r}-0.047^{\star \star \star} \\
(0.018)\end{array}$ \\
\hline Age 65+ & $\begin{array}{r}0.880 \\
(0.221)\end{array}$ & $\begin{array}{r}1.001 \\
(0.372)\end{array}$ & $\begin{array}{r}0.942 \\
(0.243)\end{array}$ & $\begin{array}{r}0.710 \\
(0.306)\end{array}$ & $\begin{array}{r}-0.059^{*} \\
(0.034)\end{array}$ & $\begin{array}{l}-0.046 \\
(0.033)\end{array}$ & $\begin{array}{r}0.007 \\
(0.022)\end{array}$ & $\begin{array}{r}-0.058^{\star \star} \\
(0.023)\end{array}$ \\
\hline Has long-term condition & $\begin{array}{r}0.977 \\
(0.042)\end{array}$ & $\begin{array}{r}1.056 \\
(0.059)\end{array}$ & $\begin{array}{r}1.111^{\star \star} \\
(0.050)\end{array}$ & $\begin{array}{r}0.963 \\
(0.068)\end{array}$ & $\begin{array}{l}-0.006 \\
(0.007)\end{array}$ & $\begin{array}{r}0.000 \\
(0.007)\end{array}$ & $\begin{array}{r}0.013^{\star * *} \\
(0.004)\end{array}$ & $\begin{array}{r}0.004 \\
(0.004)\end{array}$ \\
\hline Postgraduate & $\begin{array}{r}0.722^{\star *} \\
(0.116)\end{array}$ & $\begin{array}{r}0.735 \\
(0.187)\end{array}$ & $\begin{array}{r}0.381^{\star \star \star} \\
(0.084)\end{array}$ & $\begin{array}{r}0.328^{\star \star *} \\
(0.119)\end{array}$ & $\begin{array}{l}-0.037 \\
(0.030)\end{array}$ & $\begin{array}{l}-0.023 \\
(0.029)\end{array}$ & $\begin{array}{l}0.033^{\star} \\
(0.019)\end{array}$ & $\begin{array}{r}-0.112^{\star \star \star} \\
(0.020)\end{array}$ \\
\hline Graduate diploma & $\begin{array}{r}0.658^{* \star *} \\
(0.100)\end{array}$ & $\begin{array}{r}0.567^{\star *} \\
(0.136)\end{array}$ & $\begin{array}{r}0.305^{\star \star \star} \\
(0.066)\end{array}$ & $\begin{array}{r}0.485^{\star *} \\
(0.174)\end{array}$ & $\begin{array}{l}-0.041 \\
(0.028)\end{array}$ & $\begin{array}{l}-0.014 \\
(0.027)\end{array}$ & $\begin{array}{r}0.024 \\
(0.018)\end{array}$ & $\begin{array}{r}-0.112^{\star \star \star} \\
(0.019)\end{array}$ \\
\hline Undergraduate & $\begin{array}{r}0.864 \\
(0.089)\end{array}$ & $\begin{array}{l}0.774^{\star} \\
(0.106)\end{array}$ & $\begin{array}{r}0.481^{\star * \star} \\
(0.054)\end{array}$ & $\begin{array}{l}0.638^{*} \\
(0.150)\end{array}$ & $\begin{array}{r}0.016 \\
(0.021)\end{array}$ & $\begin{array}{r}-0.011 \\
(0.02 .)\end{array}$ & $\begin{array}{l}-0.003 \\
(0.013)\end{array}$ & $\begin{array}{r}-0.093^{* * *} \\
(0.014)\end{array}$ \\
\hline Diploma & $\begin{array}{r}0.923 \\
(0.112)\end{array}$ & $\begin{array}{r}1.129 \\
(0.195)\end{array}$ & $\begin{array}{r}0.786 \\
(0.118)\end{array}$ & $\begin{array}{r}0.993 \\
(0.244)\end{array}$ & $\begin{array}{l}0.039^{*} \\
(0.022)\end{array}$ & $\begin{array}{r}-0.074^{\star \star \star} \\
(0.022)\end{array}$ & $\begin{array}{l}-0.010 \\
(0.014)\end{array}$ & $\begin{array}{r}-0.038^{\star *} \\
(0.015)\end{array}$ \\
\hline Certificate & $\begin{array}{r}1.121 \\
(0.083)\end{array}$ & $\begin{array}{r}0.908 \\
(0.087)\end{array}$ & $\begin{array}{r}0.990 \\
(0.080)\end{array}$ & $\begin{array}{r}0.896 \\
(0.111)\end{array}$ & $\begin{array}{r}0.018 \\
(0.014)\end{array}$ & $\begin{array}{l}0.025^{\star} \\
(0.014)\end{array}$ & $\begin{array}{l}-0.011 \\
(0.009)\end{array}$ & $\begin{array}{l}-0.015 \\
(0.009)\end{array}$ \\
\hline Part-time & $\begin{array}{r}1.022 \\
(0.041)\end{array}$ & $\begin{array}{r}1.026 \\
(0.056)\end{array}$ & $\begin{array}{r}1.789^{\star \star *} \\
(0.078)\end{array}$ & $\begin{array}{r}1.091 \\
(0.079)\end{array}$ & $\begin{array}{l}-0.006 \\
(0.007)\end{array}$ & $\begin{array}{r}-0.014^{\star *} \\
(0.006)\end{array}$ & $\begin{array}{l}0.008^{*} \\
(0.004)\end{array}$ & $\begin{array}{r}0.013^{* * *} \\
(0.004)\end{array}$ \\
\hline
\end{tabular}




\begin{tabular}{|c|c|c|c|c|c|c|c|c|}
\hline \multirow[b]{2}{*}{ Predictors } & \multicolumn{4}{|c|}{ Logit - Odds Ratios } & \multicolumn{4}{|c|}{ OLS - Coefficients } \\
\hline & Private renter & Forced move & $\begin{array}{r}\text { Unaffordable } \\
\text { housing }\end{array}$ & Overcrowded & $\begin{array}{r}\text { Neighbourhood } \\
\text { crime }\end{array}$ & $\begin{array}{r}\text { Neighbourhood } \\
\text { hostility }\end{array}$ & $\begin{array}{r}\text { SEIFA - reverse } \\
\text { scored }\end{array}$ & $\begin{array}{r}\text { Precarious } \\
\text { index }\end{array}$ \\
\hline Unemployed & $\begin{array}{r}1.000 \\
(0.066)\end{array}$ & $\begin{array}{r}0.930 \\
(0.075)\end{array}$ & $\begin{array}{r}2.836^{\star \star *} \\
(0.179)\end{array}$ & $\begin{array}{r}1.235^{\star *} \\
(0.126)\end{array}$ & $\begin{array}{l}-0.002 \\
(0.012)\end{array}$ & $\begin{array}{r}0.000 \\
(0.012)\end{array}$ & $\begin{array}{r}0.023^{\star * *} \\
(0.008)\end{array}$ & $\begin{array}{r}0.061^{\star * *} \\
(0.008)\end{array}$ \\
\hline Not in labour force & $\begin{array}{r}1.085 \\
(0.057)\end{array}$ & $\begin{array}{r}0.956 \\
(0.067)\end{array}$ & $\begin{array}{r}2.975^{\star \star \star} \\
(0.159)\end{array}$ & $\begin{array}{r}1.070 \\
(0.093)\end{array}$ & $\begin{array}{r}-0.034^{\star \star \star} \\
(0.009)\end{array}$ & $\begin{array}{r}-0.034^{\star \star \star} \\
(0.009)\end{array}$ & $\begin{array}{r}0.016^{\star \star \star} \\
(0.006)\end{array}$ & $\begin{array}{r}0.027^{\star \star \star} \\
(0.006)\end{array}$ \\
\hline Balance of NSW & $\begin{array}{r}0.709^{* * *} \\
(0.072)\end{array}$ & $\begin{array}{r}0.920 \\
(0.140)\end{array}$ & $\begin{array}{r}0.909 \\
(0.119)\end{array}$ & $\begin{array}{r}0.774 \\
(0.173)\end{array}$ & $\begin{array}{r}-0.088^{\star * *} \\
(0.023)\end{array}$ & $\begin{array}{r}-0.056^{\star *} \\
(0.022)\end{array}$ & $\begin{array}{r}0.448^{\star * *} \\
(0.014)\end{array}$ & $\begin{array}{r}0.040^{* * *} \\
(0.015)\end{array}$ \\
\hline Melbourne & $\begin{array}{l}0.793^{*} \\
(0.097)\end{array}$ & $\begin{array}{r}1.096 \\
(0.204)\end{array}$ & $\begin{array}{r}0.611^{\star \star *} \\
(0.107)\end{array}$ & $\begin{array}{r}0.631 \\
(0.195)\end{array}$ & $\begin{array}{l}0.053^{*} \\
(0.029)\end{array}$ & $\begin{array}{l}-0.007 \\
(0.028)\end{array}$ & $\begin{array}{r}0.135^{\star * *} \\
(0.018)\end{array}$ & $\begin{array}{r}0.026 \\
(0.019)\end{array}$ \\
\hline Balance of VIC & $\begin{array}{l}0.766^{\star} \\
(0.111)\end{array}$ & $\begin{array}{r}0.693 \\
(0.158)\end{array}$ & $\begin{array}{r}0.729 \\
(0.140)\end{array}$ & $\begin{array}{r}0.661 \\
(0.212)\end{array}$ & $\begin{array}{r}-0.145^{\star \star \star} \\
(0.032)\end{array}$ & $\begin{array}{r}-0.086^{\star \star \star} \\
(0.031)\end{array}$ & $\begin{array}{r}0.415^{\star \star \star} \\
(0.020)\end{array}$ & $\begin{array}{r}0.002 \\
(0.022)\end{array}$ \\
\hline Brisbane & $\begin{array}{r}0.743^{\star \star} \\
(0.088)\end{array}$ & $\begin{array}{r}1.005 \\
(0.174)\end{array}$ & $\begin{array}{r}0.939 \\
(0.146)\end{array}$ & $\begin{array}{r}0.458^{\star \star \star} \\
(0.122)\end{array}$ & $\begin{array}{r}-0.055^{\star \star} \\
(0.027)\end{array}$ & $\begin{array}{r}-0.102^{\star \star \star} \\
(0.027)\end{array}$ & $\begin{array}{r}0.016 \\
(0.017)\end{array}$ & $\begin{array}{r}-0.063^{\star \star \star} \\
(0.018)\end{array}$ \\
\hline Balance of QLD & $\begin{array}{r}0.749^{\star *} \\
(0.087)\end{array}$ & $\begin{array}{r}1.104 \\
(0.184)\end{array}$ & $\begin{array}{r}1.127 \\
(0.162)\end{array}$ & $\begin{array}{r}0.760 \\
(0.196)\end{array}$ & $\begin{array}{r}-0.138^{\star \star \star} \\
(0.026)\end{array}$ & $\begin{array}{r}-0.097^{\star \star \star} \\
(0.025)\end{array}$ & $\begin{array}{r}0.285^{\star \star \star} \\
(0.016)\end{array}$ & $\begin{array}{r}0.025 \\
(0.017)\end{array}$ \\
\hline Adelaide & $\begin{array}{l}0.733^{\star} \\
(0.127)\end{array}$ & $\begin{array}{r}1.112 \\
(0.271)\end{array}$ & $\begin{array}{r}0.472^{\star \star \star} \\
(0.110)\end{array}$ & $\begin{array}{r}0.679 \\
(0.294)\end{array}$ & $\begin{array}{r}-0.075^{\star} \\
(0.040)\end{array}$ & $\begin{array}{r}-0.070^{*} \\
(0.039)\end{array}$ & $\begin{array}{r}0.311^{\star \star \star} \\
(0.025)\end{array}$ & $\begin{array}{r}0.001 \\
(0.027)\end{array}$ \\
\hline Balance of SA & $\begin{array}{r}0.829 \\
(0.173)\end{array}$ & $\begin{array}{r}1.563 \\
(0.482)\end{array}$ & $\begin{array}{l}0.600^{*} \\
(0.166)\end{array}$ & $\begin{array}{r}0.539 \\
(0.284)\end{array}$ & $\begin{array}{r}-0.097^{\star *} \\
(0.048)\end{array}$ & $\begin{array}{r}0.073 \\
(0.047)\end{array}$ & $\begin{array}{r}0.441^{\star \star \star} \\
(0.030)\end{array}$ & $\begin{array}{r}0.078^{\star \star} \\
(0.032)\end{array}$ \\
\hline Perth & $\begin{array}{r}0.703^{\star *} \\
(0.108)\end{array}$ & $\begin{array}{r}1.123 \\
(0.284)\end{array}$ & $\begin{array}{r}0.572^{* *} \\
(0.136)\end{array}$ & $\begin{array}{r}0.334^{* *} \\
(0.147)\end{array}$ & $\begin{array}{r}0.091^{* *} \\
(0.037)\end{array}$ & $\begin{array}{l}-0.039 \\
(0.036)\end{array}$ & $\begin{array}{r}-0.046^{\star *} \\
(0.023)\end{array}$ & $\begin{array}{l}-0.027 \\
(0.025)\end{array}$ \\
\hline Balance of WA & $\begin{array}{r}1.015 \\
(0.206)\end{array}$ & $\begin{array}{r}0.962 \\
(0.303)\end{array}$ & $\begin{array}{r}0.751 \\
(0.207)\end{array}$ & $\begin{array}{r}1.836 \\
(0.780)\end{array}$ & $\begin{array}{r}0.040 \\
(0.046)\end{array}$ & $\begin{array}{r}0.035 \\
(0.045)\end{array}$ & $\begin{array}{r}0.241^{\star \star \star} \\
(0.029)\end{array}$ & $\begin{array}{r}0.068^{\star \star} \\
(0.031)\end{array}$ \\
\hline Tasmania & $\begin{array}{r}0.699 \\
(0.155)\end{array}$ & $\begin{array}{r}0.503^{\star \star} \\
(0.146)\end{array}$ & $\begin{array}{r}0.738 \\
(0.185)\end{array}$ & $\begin{array}{r}1.443 \\
(0.881)\end{array}$ & $\begin{array}{r}-0.131^{\star \star \star} \\
(0.046)\end{array}$ & $\begin{array}{r}-0.130^{\star \star *} \\
(0.044)\end{array}$ & $\begin{array}{r}0.270^{\star * *} \\
(0.029)\end{array}$ & $\begin{array}{r}-0.087^{\star \star \star} \\
(0.031)\end{array}$ \\
\hline Northern Territory & $\begin{array}{r}0.637^{\star \star \star} \\
(0.110)\end{array}$ & $\begin{array}{r}0.724 \\
(0.222)\end{array}$ & $\begin{array}{r}0.421^{\star \star \star} \\
(0.125)\end{array}$ & $\begin{array}{r}0.696 \\
(0.286)\end{array}$ & $\begin{array}{r}0.113^{\star * \star} \\
(0.043)\end{array}$ & $\begin{array}{r}0.264^{\star \star \star} \\
(0.042)\end{array}$ & $\begin{array}{l}-0.033 \\
(0.027)\end{array}$ & $\begin{array}{r}0.023 \\
(0.029)\end{array}$ \\
\hline Australian Capital Territory & $\begin{array}{l}0.728^{*} \\
(0.127)\end{array}$ & $\begin{array}{r}1.293 \\
(0.353)\end{array}$ & $\begin{array}{r}1.092 \\
(0.295)\end{array}$ & $\begin{array}{r}0.225^{\star \star *} \\
(0.099)\end{array}$ & $\begin{array}{l}-0.014 \\
(0.039)\end{array}$ & $\begin{array}{r}-0.149 * \star \star \\
(0.038)\end{array}$ & $\begin{array}{r}-0.255^{\star \star \star} \\
(0.024)\end{array}$ & $\begin{array}{r}-0.119 * \star * \\
(0.026)\end{array}$ \\
\hline
\end{tabular}




\begin{tabular}{|c|c|c|c|c|c|c|c|c|}
\hline \multirow[b]{2}{*}{ Predictors } & \multicolumn{4}{|c|}{ Logit - Odds Ratios } & \multicolumn{4}{|c|}{ OLS - Coefficients } \\
\hline & Private renter & Forced move & $\begin{array}{r}\text { Unaffordable } \\
\text { housing }\end{array}$ & Overcrowded & $\begin{array}{r}\text { Neighbourhood } \\
\text { crime }\end{array}$ & $\begin{array}{r}\text { Neighbourhood } \\
\text { hostility }\end{array}$ & $\begin{array}{r}\text { SEIFA - reverse } \\
\text { scored }\end{array}$ & $\begin{array}{r}\text { Precarious } \\
\text { index }\end{array}$ \\
\hline $\begin{array}{l}\text { Real, equivalised disposable } \\
\text { income }\left(\$^{\prime} 00,000\right)\end{array}$ & $\begin{array}{r}0.793^{* * *} \\
(0.036)\end{array}$ & $\begin{array}{r}1.035 \\
(0.074)\end{array}$ & $\begin{array}{r}0.427^{\star \star *} \\
(0.034)\end{array}$ & $\begin{array}{r}0.662^{* \star *} \\
(0.080)\end{array}$ & $\begin{array}{l}-0.003 \\
(0.005)\end{array}$ & $\begin{array}{l}-0.001 \\
(0.005)\end{array}$ & $\begin{array}{r}-0.013^{* * *} \\
(0.003)\end{array}$ & $\begin{array}{r}-0.008^{* *} \\
(0.003)\end{array}$ \\
\hline Wave 2 & $\begin{array}{r}0.922 \\
(0.065)\end{array}$ & $\begin{array}{r}0.890 \\
(0.085)\end{array}$ & $\begin{array}{r}1.091 \\
(0.092)\end{array}$ & $\begin{array}{l}0.791^{*} \\
(0.097)\end{array}$ & $\begin{array}{r}-0.052^{\star \star \star} \\
(0.011)\end{array}$ & $\begin{array}{l}0.020^{*} \\
(0.011)\end{array}$ & $\begin{array}{l}-0.004 \\
(0.007)\end{array}$ & $\begin{array}{l}-0.012 \\
(0.007)\end{array}$ \\
\hline Wave 3 & $\begin{array}{r}0.932 \\
(0.068)\end{array}$ & $\begin{array}{r}0.772^{\star *} \\
(0.078)\end{array}$ & $\begin{array}{r}1.062 \\
(0.091)\end{array}$ & $\begin{array}{r}0.728^{* *} \\
(0.091)\end{array}$ & $\begin{array}{r}-0.097^{\star \star *} \\
(0.011)\end{array}$ & $\begin{array}{l}0.022^{*} \\
(0.011)\end{array}$ & $\begin{array}{l}-0.006 \\
(0.007)\end{array}$ & $\begin{array}{r}-0.028^{* * *} \\
(0.008)\end{array}$ \\
\hline Wave 4 & $\begin{array}{r}0.917 \\
(0.068)\end{array}$ & $\begin{array}{l}0.849^{*} \\
(0.084)\end{array}$ & $\begin{array}{r}1.047 \\
(0.091)\end{array}$ & $\begin{array}{r}0.763^{\star *} \\
(0.097)\end{array}$ & $\begin{array}{r}-0.100^{* * *} \\
(0.012)\end{array}$ & $\begin{array}{l}0.020^{*} \\
(0.011)\end{array}$ & $\begin{array}{r}-0.024^{\star * \star} \\
(0.008)\end{array}$ & $\begin{array}{r}-0.028^{* * *} \\
(0.008)\end{array}$ \\
\hline Wave 5 & $\begin{array}{r}0.896 \\
(0.068)\end{array}$ & $\begin{array}{r}0.754^{\star \star \star} \\
(0.077)\end{array}$ & $\begin{array}{r}1.129 \\
(0.098)\end{array}$ & $\begin{array}{r}0.766^{\star \star} \\
(0.099)\end{array}$ & $\begin{array}{r}-0.155^{\star \star \star} \\
(0.012)\end{array}$ & $\begin{array}{r}0.015 \\
(0.012)\end{array}$ & $\begin{array}{r}-0.025^{\star \star \star} \\
(0.008)\end{array}$ & $\begin{array}{r}-0.050^{\star \star \star \star} \\
(0.008)\end{array}$ \\
\hline Wave 6 & $\begin{array}{r}0.833^{\star \star} \\
(0.064)\end{array}$ & $\begin{array}{r}0.691^{\star \star \star} \\
(0.073)\end{array}$ & $\begin{array}{r}1.264^{\star \star \star} \\
(0.110)\end{array}$ & $\begin{array}{r}0.823 \\
(0.107)\end{array}$ & $\begin{array}{r}-0.164^{\star \star \star} \\
(0.012)\end{array}$ & $\begin{array}{r}0.017 \\
(0.012)\end{array}$ & $\begin{array}{r}-0.035^{\star \star \star} \\
(0.008)\end{array}$ & $\begin{array}{r}-0.050^{\star \star \star \star} \\
(0.008)\end{array}$ \\
\hline Wave 7 & $\begin{array}{r}0.698^{\star \star \star} \\
(0.055)\end{array}$ & $\begin{array}{r}0.633^{\star \star \star} \\
(0.069)\end{array}$ & $\begin{array}{r}1.274^{\star \star \star} \\
(0.114)\end{array}$ & $\begin{array}{r}0.874 \\
(0.115)\end{array}$ & $\begin{array}{r}-0.180^{\star \star \star} \\
(0.012)\end{array}$ & $\begin{array}{l}0.023^{\star} \\
(0.012)\end{array}$ & $\begin{array}{r}-0.036^{\star \star \star} \\
(0.008)\end{array}$ & $\begin{array}{r}-0.054^{\star \star \star} \\
(0.008)\end{array}$ \\
\hline Wave 8 & $\begin{array}{r}0.776^{\star \star \star} \\
(0.063)\end{array}$ & $\begin{array}{r}0.710^{* * *} \\
(0.078)\end{array}$ & $\begin{array}{r}1.009 \\
(0.094)\end{array}$ & $\begin{array}{l}0.786^{*} \\
(0.107)\end{array}$ & $\begin{array}{r}-0.190^{* \star \star} \\
(0.013)\end{array}$ & $\begin{array}{c}0.022^{\star} \\
(0.013)\end{array}$ & $\begin{array}{r}-0.044^{\star \star \star} \\
(0.008)\end{array}$ & $\begin{array}{r}-0.065^{\star \star \star} \\
(0.008)\end{array}$ \\
\hline Wave 9 & $\begin{array}{r}0.739 * \star \star \\
(0.061)\end{array}$ & $\begin{array}{r}0.612^{\star \star \star} \\
(0.070)\end{array}$ & $\begin{array}{r}1.542^{\star \star \star} \\
(0.140)\end{array}$ & $\begin{array}{r}1.009 \\
(0.136)\end{array}$ & $\begin{array}{r}-0.205^{\star \star \star} \\
(0.013)\end{array}$ & $\begin{array}{r}0.015 \\
(0.013)\end{array}$ & $\begin{array}{r}-0.038^{\star \star \star} \\
(0.008)\end{array}$ & $\begin{array}{r}-0.055^{\star \star \star} \\
(0.008)\end{array}$ \\
\hline Wave 10 & $\begin{array}{r}0.744^{\star * \star} \\
(0.062)\end{array}$ & $\begin{array}{r}0.589^{* \star *} \\
(0.068)\end{array}$ & $\begin{array}{r}1.263^{\star *} \\
(0.117)\end{array}$ & $\begin{array}{r}0.883 \\
(0.122)\end{array}$ & $\begin{array}{r}-0.205^{\star \star \star} \\
(0.013)\end{array}$ & $\begin{array}{r}0.012 \\
(0.013)\end{array}$ & $\begin{array}{r}-0.036^{\star \star *} \\
(0.008)\end{array}$ & $\begin{array}{r}-0.060^{\star \star \star} \\
(0.009)\end{array}$ \\
\hline Wave 11 & $\begin{array}{r}0.711^{\star \star \star} \\
(0.060)\end{array}$ & $\begin{array}{r}0.544^{\star * \star} \\
(0.063)\end{array}$ & $\begin{array}{l}1.196^{\star} \\
(0.112)\end{array}$ & $\begin{array}{r}0.807 \\
(0.113)\end{array}$ & $\begin{array}{r}-0.219^{\star \star \star} \\
(0.013)\end{array}$ & $\begin{array}{r}-0.024^{\star} \\
(0.013)\end{array}$ & $\begin{array}{r}-0.039^{\star \star \star} \\
(0.008)\end{array}$ & $\begin{array}{r}-0.082^{\star * \star} \\
(0.009)\end{array}$ \\
\hline Wave 12 & $\begin{array}{r}0.690^{* \star \star} \\
(0.060)\end{array}$ & $\begin{array}{r}0.510^{* * *} \\
(0.061)\end{array}$ & $\begin{array}{l}1.204^{\star} \\
(0.116)\end{array}$ & $\begin{array}{r}0.641^{\star \star *} \\
(0.095)\end{array}$ & $\begin{array}{r}-0.217^{* * \star} \\
(0.013)\end{array}$ & $\begin{array}{l}-0.021 \\
(0.013)\end{array}$ & $\begin{array}{r}-0.051^{\star * \star} \\
(0.009)\end{array}$ & $\begin{array}{r}-0.091^{\star \star \star} \\
(0.009)\end{array}$ \\
\hline Wave 13 & $\begin{array}{r}0.626^{\star \star \star} \\
(0.056)\end{array}$ & $\begin{array}{r}0.439 * * * \\
(0.055)\end{array}$ & $\begin{array}{r}1.063 \\
(0.106)\end{array}$ & $\begin{array}{r}0.782 \\
(0.118)\end{array}$ & $\begin{array}{r}-0.254^{\star \star \star} \\
(0.014)\end{array}$ & $\begin{array}{r}-0.064^{\star \star \star} \\
(0.014)\end{array}$ & $\begin{array}{r}-0.047^{* * *} \\
(0.009)\end{array}$ & $\begin{array}{r}-0.116^{\star \star \star} \\
(0.009)\end{array}$ \\
\hline Wave 14 & $\begin{array}{r}0.700 * \star * \\
(0.065)\end{array}$ & $\begin{array}{r}0.516^{\star \star \star} \\
(0.066)\end{array}$ & $\begin{array}{r}1.046 \\
(0.107)\end{array}$ & $\begin{array}{l}0.752^{\star} \\
(0.116)\end{array}$ & $\begin{array}{r}-0.247^{\star * \star} \\
(0.014)\end{array}$ & $\begin{array}{r}-0.068^{\star \star \star} \\
(0.014)\end{array}$ & $\begin{array}{r}-0.054^{* * *} \\
(0.009)\end{array}$ & $\begin{array}{r}-0.110^{\star \star *} \\
(0.009)\end{array}$ \\
\hline
\end{tabular}




\begin{tabular}{|c|c|c|c|c|c|c|c|c|c|}
\hline \multirow[b]{2}{*}{ Predictors } & \multicolumn{4}{|c|}{ Logit - Odds Ratios } & & \multicolumn{4}{|c|}{ OLS - Coefficients } \\
\hline & Private renter & Forced move & $\begin{array}{r}\text { Unaffordable } \\
\text { housing }\end{array}$ & Overcrowded & & $\begin{array}{r}\text { Neighbourhood } \\
\text { crime }\end{array}$ & $\begin{array}{r}\text { Neighbourhood } \\
\text { hostility }\end{array}$ & $\begin{array}{r}\text { SEIFA - reverse } \\
\text { scored }\end{array}$ & $\begin{array}{r}\text { Precarious } \\
\text { index }\end{array}$ \\
\hline Wave 15 & $\begin{array}{r}0.690^{\star \star \star} \\
(0.066)\end{array}$ & $\begin{array}{r}0.471^{\star \star \star} \\
(0.063)\end{array}$ & $\begin{array}{r}1.062 \\
(0.112)\end{array}$ & $\begin{array}{r}0.607^{\star \star \star} \\
(0.099)\end{array}$ & & $\begin{array}{r}-0.240^{\star * \star} \\
(0.015)\end{array}$ & $\begin{array}{r}-0.087^{\star \star \star} \\
(0.014)\end{array}$ & $\begin{array}{r}-0.059^{\star \star \star} \\
(0.009)\end{array}$ & $\begin{array}{r}-0.122^{\star \star *} \\
(0.010)\end{array}$ \\
\hline Wave 16 & $\begin{array}{r}0.643^{\star * *} \\
(0.064)\end{array}$ & $\begin{array}{r}0.403^{* * *} \\
(0.056)\end{array}$ & $\begin{array}{r}1.095 \\
(0.119)\end{array}$ & $\begin{array}{r}0.550^{* \star *} \\
(0.092)\end{array}$ & & $\begin{array}{r}-0.233^{\star \star \star} \\
(0.015)\end{array}$ & $\begin{array}{r}-0.083^{\star \star \star} \\
(0.015)\end{array}$ & $\begin{array}{r}-0.062^{\star * \star} \\
(0.010)\end{array}$ & $\begin{array}{r}-0.126^{\star \star \star} \\
(0.010)\end{array}$ \\
\hline \multirow[t]{2}{*}{ Wave 17} & $\begin{array}{r}0.526^{\star \star \star} \\
(0.054)\end{array}$ & $\begin{array}{r}0.414^{\star \star \star} \\
(0.060)\end{array}$ & $\begin{array}{r}0.949 \\
(0.108)\end{array}$ & $\begin{array}{r}0.613^{\star \star \star} \\
(0.105)\end{array}$ & & $\begin{array}{r}-0.233^{\star \star \star} \\
(0.016)\end{array}$ & $\begin{array}{r}-0.090^{\star \star \star} \\
(0.015)\end{array}$ & $\begin{array}{r}-0.061^{\star \star \star} \\
(0.010)\end{array}$ & $\begin{array}{r}-0.127^{\star \star \star} \\
(0.010)\end{array}$ \\
\hline & & & & & Constant & $\begin{array}{r}2.982^{\star \star *} \\
(0.033)\end{array}$ & $\begin{array}{r}2.625^{\star \star *} \\
(0.033)\end{array}$ & $\begin{array}{r}2.115^{\star \star \star} \\
(0.021)\end{array}$ & $\begin{array}{r}1.464^{\star \star \star} \\
(0.022)\end{array}$ \\
\hline $\mathbf{N}$ & 55,796 & 30,759 & 41,484 & 17,765 & $\mathbf{N}$ & 140,423 & 146,707 & 150,437 & 138,500 \\
\hline Pseudo $\mathrm{R}^{2}$ & 0.261 & 0.064 & 0.065 & 0.039 & $\mathbf{R}^{2}$ & 0.043 & 0.048 & 0.152 & 0.127 \\
\hline LR Chi ${ }^{2}$ & $11,408.73^{\star \star \star}$ & $1,140.66^{\star \star \star}$ & $1,874.87^{\star \star \star}$ & $447.84^{\star \star \star}$ & F-stat & $36.63^{\star \star \star}$ & $23.38^{\star \star \star}$ & $58.44^{\star \star \star}$ & $45.42^{\star \star \star}$ \\
\hline
\end{tabular}

Notes: ${ }^{* *} p<0.01,{ }^{* *} p<0.05,{ }^{*} p<0.1$. The reference categories are outright owner, no dependent children, legally married, age 15-24, highest qualification from high school, full-time employed, Sydney and Wave 1. Standard errors are reported in parentheses.

Source: HILDA survey 2002-2018. 
Table A4: Effect of housing precariousness and housing assistance at $t$ on overall wellbeing at $t+1$, random effects OLS models, 2002-2018

\begin{tabular}{|c|c|c|}
\hline Predictors & $\begin{array}{l}\text { Renters with a high } \\
\text { precarious index score }\end{array}$ & $\begin{array}{l}\text { Renters who experience at } \\
\text { least } 1 \text { form of precariousness }\end{array}$ \\
\hline CRA indicator deviation from the mean & $\begin{array}{l}-0.016 \\
(0.017)\end{array}$ & $\begin{array}{l}-0.015 \\
(0.014)\end{array}$ \\
\hline CRA indicator mean & $\begin{array}{r}-0.433^{\star \star *} \\
(0.035)\end{array}$ & $\begin{array}{r}-0.439^{\star * *} \\
(0.031)\end{array}$ \\
\hline Public-housing indicator deviation from the mean & $\begin{array}{r}0.014 \\
(0.035)\end{array}$ & $\begin{array}{r}0.010 \\
(0.029)\end{array}$ \\
\hline Public-housing indicator mean & $\begin{array}{r}-0.540^{\star * *} \\
(0.048)\end{array}$ & $\begin{array}{r}-0.498^{\star \star \star} \\
(0.042)\end{array}$ \\
\hline Forced move & $\begin{array}{r}-0.069^{\star * *} \\
(0.017)\end{array}$ & $\begin{array}{r}-0.074^{\star * *} \\
(0.015)\end{array}$ \\
\hline Unaffordability & $\begin{array}{r}-0.028^{*} \\
(0.016)\end{array}$ & $\begin{array}{l}-0.011 \\
(0.014)\end{array}$ \\
\hline Overcrowded & $\begin{array}{r}0.009 \\
(0.022)\end{array}$ & $\begin{array}{l}-0.007 \\
(0.019)\end{array}$ \\
\hline Neighbourhood crime & $\begin{array}{r}-0.040^{\star * \star} \\
(0.008)\end{array}$ & $\begin{array}{r}-0.030^{* \star \star} \\
(0.006)\end{array}$ \\
\hline Neighbourhood hostility & $\begin{array}{r}-0.021^{\star \star \star} \\
(0.008)\end{array}$ & $\begin{array}{r}-0.027^{\star \star \star} \\
(0.006)\end{array}$ \\
\hline SEIFA index reverse scored, divided by 100 & $\begin{array}{r}-0.022^{\star * \star} \\
(0.008)\end{array}$ & $\begin{array}{r}-0.023^{\star * \star} \\
(0.007)\end{array}$ \\
\hline Children & $\begin{array}{r}0.049^{\star \star \star} \\
(0.019)\end{array}$ & $\begin{array}{r}0.039^{\star \star} \\
(0.016)\end{array}$ \\
\hline De facto & $\begin{array}{l}-0.036 \\
(0.023)\end{array}$ & $\begin{array}{r}-0.052^{\star \star \star} \\
(0.019)\end{array}$ \\
\hline Separated & $\begin{array}{r}-0.092^{\star \star \star} \\
(0.033)\end{array}$ & $\begin{array}{r}-0.103^{\star \star \star} \\
(0.029)\end{array}$ \\
\hline Divorced & $\begin{array}{r}-0.069^{\star \star} \\
(0.033)\end{array}$ & $\begin{array}{r}-0.119 * \star \star \\
(0.028)\end{array}$ \\
\hline Widowed & $\begin{array}{l}-0.005 \\
(0.074)\end{array}$ & $\begin{array}{r}0.057 \\
(0.057)\end{array}$ \\
\hline Single, not married & $\begin{array}{r}-0.074^{\star \star \star} \\
(0.025)\end{array}$ & $\begin{array}{r}-0.078^{* * *} \\
(0.021)\end{array}$ \\
\hline Age 25-34 & $\begin{array}{r}-0.084^{\star * *} \\
(0.020)\end{array}$ & $\begin{array}{r}-0.060^{* * *} \\
(0.017)\end{array}$ \\
\hline Age $35-44$ & $\begin{array}{r}-0.179^{\star * *} \\
(0.025)\end{array}$ & $\begin{array}{r}-0.152^{\star * \star} \\
(0.022)\end{array}$ \\
\hline Age $45-54$ & $\begin{array}{r}-0.278^{* * *} \\
(0.030)\end{array}$ & $\begin{array}{r}-0.252^{* * *} \\
(0.025)\end{array}$ \\
\hline Age 55-64 & $\begin{array}{r}-0.346^{\star * *} \\
(0.038)\end{array}$ & $\begin{array}{r}-0.274^{\star * *} \\
(0.032)\end{array}$ \\
\hline Age 65+ & $\begin{array}{l}-0.012 \\
(0.062)\end{array}$ & $\begin{array}{l}-0.003 \\
(0.048)\end{array}$ \\
\hline
\end{tabular}




\begin{tabular}{|c|c|c|}
\hline Predictors & $\begin{array}{l}\text { Renters with a high } \\
\text { precarious index score }\end{array}$ & $\begin{array}{r}\text { Renters who experience at } \\
\text { least } 1 \text { form of precariousness }\end{array}$ \\
\hline Has long-term condition & $\begin{array}{r}-0.244^{\star \star \star} \\
(0.016)\end{array}$ & $\begin{array}{r}-0.237^{* \star *} \\
(0.014)\end{array}$ \\
\hline Postgraduate & $\begin{array}{r}0.054 \\
(0.056)\end{array}$ & $\begin{array}{r}0.036 \\
(0.047)\end{array}$ \\
\hline Graduate Diploma & $\begin{array}{r}0.017 \\
(0.056)\end{array}$ & $\begin{array}{r}0.021 \\
(0.047)\end{array}$ \\
\hline Undergraduate & $\begin{array}{r}0.098^{\star \star \star} \\
(0.029)\end{array}$ & $\begin{array}{r}0.093^{\star \star \star} \\
(0.025)\end{array}$ \\
\hline Diploma & $\begin{array}{r}0.089^{\star *} \\
(0.035)\end{array}$ & $\begin{array}{r}0.073^{\star \star} \\
(0.030)\end{array}$ \\
\hline Certificate & $\begin{array}{r}0.032 \\
(0.022)\end{array}$ & $\begin{array}{r}0.025 \\
(0.019)\end{array}$ \\
\hline Part-time & $\begin{array}{r}-0.051^{\star \star \star} \\
(0.017)\end{array}$ & $\begin{array}{r}-0.027^{*} \\
(0.015)\end{array}$ \\
\hline Unemployed & $\begin{array}{r}-0.189^{\star \star \star} \\
(0.024)\end{array}$ & $\begin{array}{r}-0.177^{\star \star \star} \\
(0.020)\end{array}$ \\
\hline Not in labour force & $\begin{array}{r}-0.266^{\star \star \star} \\
(0.020)\end{array}$ & $\begin{array}{r}-0.240^{\star \star \star} \\
(0.017)\end{array}$ \\
\hline Balance of NSW & $\begin{array}{l}0.060^{*} \\
(0.033)\end{array}$ & $\begin{array}{r}0.087^{\star \star *} \\
(0.029)\end{array}$ \\
\hline Melbourne & $\begin{array}{l}-0.010 \\
(0.034)\end{array}$ & $\begin{array}{l}-0.002 \\
(0.029)\end{array}$ \\
\hline Balance of VIC & $\begin{array}{r}0.061 \\
(0.045)\end{array}$ & $\begin{array}{l}0.067^{\star} \\
(0.038)\end{array}$ \\
\hline Brisbane & $\begin{array}{r}0.047 \\
(0.035)\end{array}$ & $\begin{array}{r}0.024 \\
(0.030)\end{array}$ \\
\hline Balance of QLD & $\begin{array}{r}0.048 \\
(0.033)\end{array}$ & $\begin{array}{r}0.035 \\
(0.028)\end{array}$ \\
\hline Adelaide & $\begin{array}{r}0.002 \\
(0.043)\end{array}$ & $\begin{array}{r}0.003 \\
(0.037)\end{array}$ \\
\hline Balance of SA & $\begin{array}{r}0.133^{\star *} \\
(0.060)\end{array}$ & $\begin{array}{r}0.135^{\star \star *} \\
(0.051)\end{array}$ \\
\hline Perth & $\begin{array}{l}-0.033 \\
(0.044)\end{array}$ & $\begin{array}{l}-0.018 \\
(0.038)\end{array}$ \\
\hline Balance of WA & $\begin{array}{r}0.080 \\
(0.061)\end{array}$ & $\begin{array}{r}0.107^{\star \star} \\
(0.054)\end{array}$ \\
\hline Tasmania & $\begin{array}{r}0.077 \\
(0.054)\end{array}$ & $\begin{array}{r}0.039 \\
(0.047)\end{array}$ \\
\hline Northern Territory & $\begin{array}{r}0.001 \\
(0.079)\end{array}$ & $\begin{array}{r}0.026 \\
(0.068)\end{array}$ \\
\hline Australian Capital Territory & $\begin{array}{l}-0.130 \\
(0.076)\end{array}$ & $\begin{array}{l}-0.025 \\
(0.062)\end{array}$ \\
\hline Real, equivalised disposable income $(\$ 00,000)$ & $\begin{array}{r}0.080^{\star \star \star} \\
(0.021)\end{array}$ & $\begin{array}{r}0.110^{\star \star \star} \\
(0.027)\end{array}$ \\
\hline
\end{tabular}




\begin{tabular}{|c|c|c|}
\hline Predictors & $\begin{array}{l}\text { Renters with a high } \\
\text { precarious index score }\end{array}$ & $\begin{array}{l}\text { Renters who experience at } \\
\text { least } 1 \text { form of precariousness }\end{array}$ \\
\hline Wave 3 & $\begin{array}{r}0.011 \\
(0.032)\end{array}$ & $\begin{array}{r}0.110^{* \star \star} \\
(0.027)\end{array}$ \\
\hline Wave 4 & $\begin{array}{l}-0.022 \\
(0.032)\end{array}$ & $\begin{array}{r}0.082^{\star \star \star} \\
(0.023)\end{array}$ \\
\hline Wave 5 & $\begin{array}{l}-0.008 \\
(0.032)\end{array}$ & $\begin{array}{r}0.074^{\star \star \star} \\
(0.024)\end{array}$ \\
\hline Wave 6 & $\begin{array}{r}0.058 \\
(0.033)\end{array}$ & $\begin{array}{r}0.075^{\star \star \star} \\
(0.025)\end{array}$ \\
\hline Wave 7 & $\begin{array}{r}0.051 \\
(0.035)\end{array}$ & $\begin{array}{r}0.134^{\star * *} \\
(0.025)\end{array}$ \\
\hline Wave 8 & $\begin{array}{r}0.010 \\
(0.033)\end{array}$ & $\begin{array}{r}0.112^{\star \star \star} \\
(0.027)\end{array}$ \\
\hline Wave 9 & $\begin{array}{l}-0.020 \\
(0.034)\end{array}$ & $\begin{array}{r}0.080^{* *} \\
(0.025)\end{array}$ \\
\hline Wave 10 & $\begin{array}{r}0.016 \\
(0.032)\end{array}$ & $\begin{array}{r}0.061^{\star * \star} \\
(0.026)\end{array}$ \\
\hline Wave 11 & $\begin{array}{r}0.018 \\
(0.034)\end{array}$ & $\begin{array}{r}0.100^{* * *} \\
(0.025)\end{array}$ \\
\hline Wave 12 & $\begin{array}{l}-0.006 \\
(0.031)\end{array}$ & $\begin{array}{r}0.099^{* \star *} \\
(0.026)\end{array}$ \\
\hline Wave 13 & $\begin{array}{l}-0.026 \\
(0.033)\end{array}$ & $\begin{array}{r}0.066^{\star *} \\
(0.023)\end{array}$ \\
\hline Wave 14 & $\begin{array}{l}-0.037 \\
(0.032)\end{array}$ & $\begin{array}{r}0.063^{\star \star} \\
(0.024)\end{array}$ \\
\hline Wave 15 & $\begin{array}{l}-0.016 \\
(0.033)\end{array}$ & $\begin{array}{r}0.048^{\star *} \\
(0.024)\end{array}$ \\
\hline Wave 16 & $\begin{array}{r}0.010 \\
(0.032)\end{array}$ & $\begin{array}{r}0.057^{\star \star *} \\
(0.025)\end{array}$ \\
\hline Wave 17 & $\begin{array}{r}0.045 \\
(0.033)\end{array}$ & $\begin{array}{r}0.094^{\star \star *} \\
(0.024)\end{array}$ \\
\hline Constant & $\begin{array}{r}4.931^{\star \star \star} \\
(0.054)\end{array}$ & $\begin{array}{r}4.831^{\star \star \star} \\
(0.045)\end{array}$ \\
\hline N & 13,756 & 19,131 \\
\hline R2 & 0.206 & 0.196 \\
\hline F-stat & 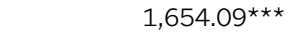 & $2,056.24^{\star \star \star}$ \\
\hline
\end{tabular}

Notes: ${ }^{* *} p<0.01,{ }^{*} p<0.05,{ }^{*} p<0.1$. The reference categories are outright owner, no dependent children, legally married, age 15-24, highest qualification from high school, full-time employed, Sydney and Wave 2. Standard errors are reported in parentheses.

Source: HILDA survey 2002-2018. 


\section{AHURi}

Australian Housing and Urban Research Institute Level 12, 460 Bourke Street

Melbourne VIC 3000

\section{Australia}

+61396602300

information@ahuri.edu.au

ahuri.edu.au

(2) twitter.com/AHURI_Research

f facebook.com/AHURI.AUS

in Australian Housing and Urban Research Institute 